PAULA RACCANELLO STORTO

LIBERDADE DE ASSOCIAÇÃO E OS DESAFIOS DAS ORGANIZAÇÕES DA SOCIEDADE CIVIL NO BRASIL

Universidade de São Paulo

Faculdade de Direito

São Paulo - SP

2014 


\section{LIBERDADE DE ASSOCIAÇÃO E OS DESAFIOS DAS ORGANIZAÇÕES DA SOCIEDADE CIVIL NO BRASIL}

Dissertação apresentada à Banca Examinadora do Programa de Pós Graduação em Direito, da Faculdade de Direito da Universidade de São Paulo, como exigência parcial da obtenção do título de Mestre em Direito, na área de concentração de Direitos Humanos, sob orientação da Profa. Dra. Eunice Aparecida de Jesus Prudente.

Versão corrigida em 10 de maio de 2015. A versão original em formato eletrônico (PDF) encontra-se disponível na CPG da Unidade.

Universidade de São Paulo

Faculdade de Direito

São Paulo - SP 
Autorizo a reprodução e divulgação total ou parcial deste trabalho, por qualquer meio convencional ou eletrônico, para fins de estudo e pesquisa, desde que citada a fonte.

Storto, Paula Raccanello

Liberdade de Associação e os Desafios das Organizações da Sociedade Civil no Brasil / Paula Raccanello Storto ; orientadora Eunice Aparecida de Jesus Prudente. - São Paulo, 2014.

$132 \mathrm{f}$.

Dissertação (Mestrado)- Faculdade de Direito da Universidade de São Paulo. Departamento de Direitos Humanos.

Área de concentração: Direitos Humanos.

1. Direitos Humanos . 2. Liberdade de Associação .

3. Organização Não-Governamental . 4. Cidadania . 5.

Convenio Administrativo . I. Prudente, Eunice

Aparecida de Jesus, orient. II. Título. 
Nome: Paula Raccanello Storto

\section{TíTULO: LIBERDADE DE ASSOCIAÇÃO E OS DESAFIOS DAS ORGANIZAÇÕES} DA SOCIEDADE CIVIL NO BRASIL

Dissertação apresentada ao Programa de Pós-Graduação em Direito da Universidade de São Paulo para obtenção do título de Mestre em Direito, na área de concentração de Direitos Humanos

Versão corrigida em 10 de maio de 2015. A versão original em formato eletrônico (PDF) encontra-se disponível na CPG da Unidade.

Aprovado em:

Banca Examinadora

Prof. Dr. Instituição:

Julgamento: Assinatura:

Prof. Dr. Instituição:

Julgamento: Assinatura:

Prof. Dr. Instituição:

Julgamento: Assinatura: 


\section{RESUMO}

STORTO, Paula Raccanello. Liberdade de Associação e o Desafio das Organizações da Sociedade Civil no Brasil. 2014. Mestrado, Faculdade de Direito., Universidade de São Paulo, 2014.

O presente estudo tem por objetivo identificar de que forma o direito de liberdade de associação vem sendo aplicado com relação às organizações da sociedade civil no Brasil. A partir da análise das diferentes dimensões da liberdade de associação e das normas que tratam das organizações da sociedade civil no Brasil pós Constituição Federal de 1988, apresentamos os principais desafios a serem superados para que as organizações da sociedade civil sejam tratadas de forma a melhor garantir o direito de liberdade de associação e um marco regulatório mais adequado ao seu desenvolvimento.

Palavras-chave: Liberdade de associação; Direitos Humanos; Organizações da Sociedade Civil; Terceiro Setor; Parcerias entre OSC e Estado; Lei 13.019/2014. 


\begin{abstract}
STORTO, Paula Raccanello. Freedom of Association and the Challenges to Civil Society Organizations in Brazil. 2014. Master. Faculty of Law, University of São Paulo, 2014.

The present study aims to identify how the right to freedom of association has been applied with respect to civil society organizations in Brazil. From the analysis of the different dimensions of freedom of association and rules dealing with civil society organizations in Brazil, after the Federal Constitution of 1988, we present the main challenges to be overcome so that civil society organizations can be treated to ensure right to freedom of association and a legal framework best suited to their development.
\end{abstract}

Keywords: Freedom of Association; Human Rights; Civil Society Organizations; Third Sector; Partnerships between CSOs and State; Law 13,019/2014 . 


\section{SUMÁRIO}

1 INTRODUÇÃO

2 LIBERDADE DE ASSOCIAÇÃO E ORGANIZAÇÕES DA SOCIEDADE CIVIL

2.1 LIBERDADE DE ASSOCIAÇÃO COMO DIREITO INDIVIDUAL ....................13

2.2 LIBERDADE DE ASSOCIAÇÃO COMO UMA LIBERDADE PÚBLICA ..........15

2.3 LIBERDADE DE ASSOCIAÇÃO COMO UMA LIBERDADE PÚBLICA

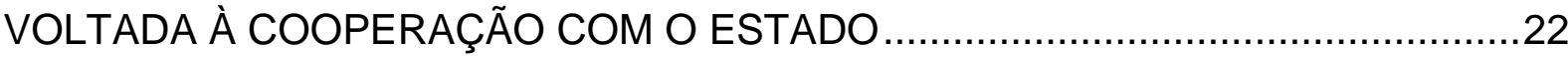

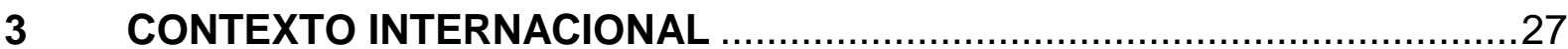

3.1 NOTAS SOBRE O DIREITO DE LIBERDADE DE ASSOCIAÇÃO NA

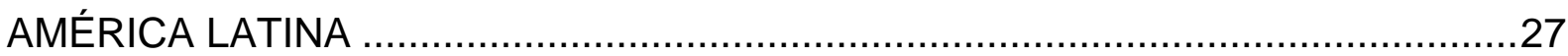

3.2 AS OSC NO CONTEXTO INTERNACIONAL .............................................

3.3 RELATORIA ESPECIAL DA ONU SOBRE LIBERDADE DE REUNIÃO E DE

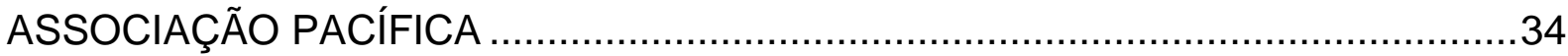

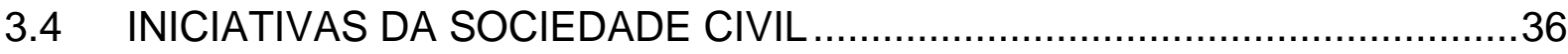

4 AS TRÊS DIMENSÕES DA LIBERDADE DE ASSOCIAÇÃO: NÃO INTERFERÊNCIA, PARTICIPAÇÃO E FINANCIAMENTO …............................40

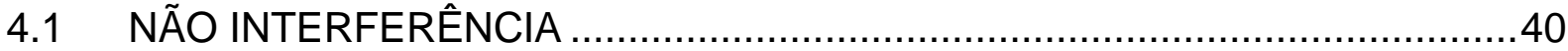

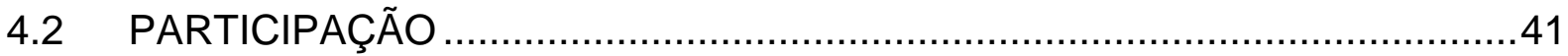

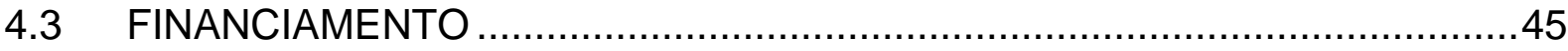

5 ELEMENTOS CARACTERIZADORES DAS ORGANIZAÇÕES DA

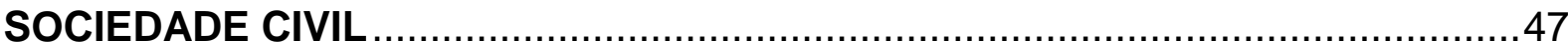

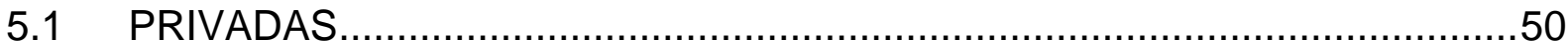

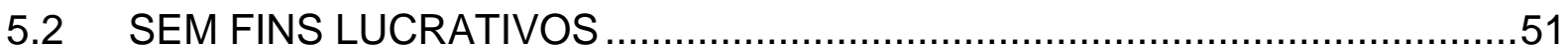

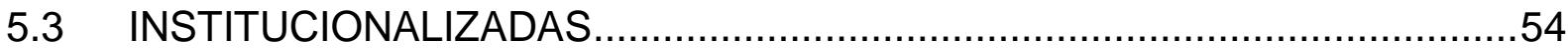

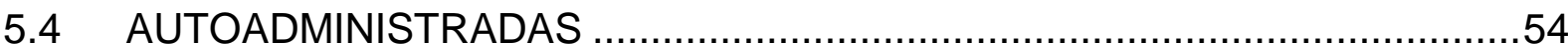

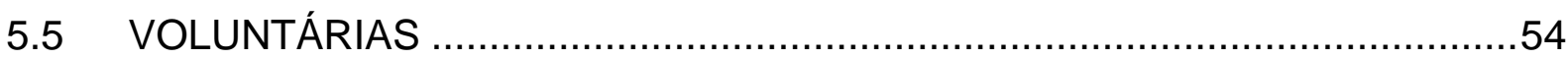

6 LEGISLAÇÃO GERAL DAS ORGANIZAÇÕES DA SOCIEDADE CIVIL.......56

6.1 FORMATAÇÃO JURÍDICA DAS ORGANIZAÇÕES ....................................56 


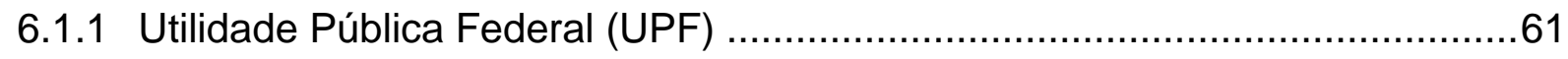

6.1.2 Organização da Sociedade Civil de Interesse Público (OSCIP) .....................61

6.1.3 Certificado de Entidade Beneficente de Assistência Social (CEBAS) ............63

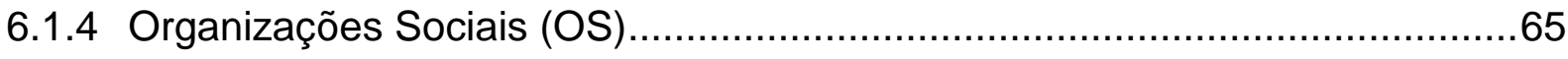

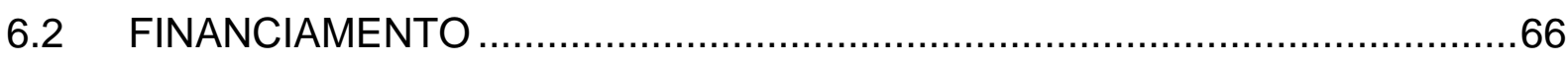

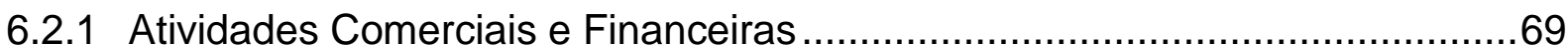

6.2.2 Controles, Transparência e Obrigação de Prestar Contas …………….........70

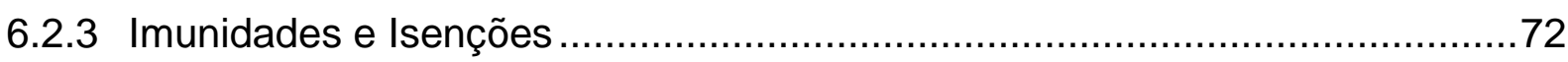

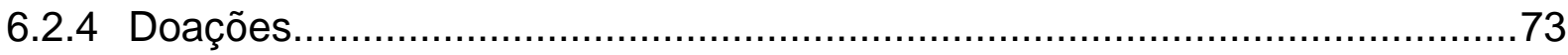

7 ANÁLISE DA LEGISLAÇÃO SOBRE ORGANIZAÇÕES DA SOCIEDADE

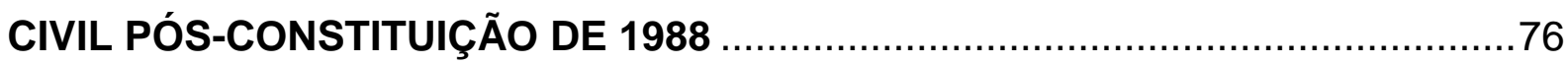

7.1 FASES DISTINTAS: REDEMOCRATIZAÇÃO, PARTICIPAÇÃO, CONTRATUALIZAÇÃO, CONTROLE E ORGANIZAÇÃO ….................................76

7.1.1 Diagnóstico das Relações de Contratualização............................................. 80

7.2 O PROGRAMA DO MARCO REGULATÓRIO DAS ORGANIZAÇÕES DA

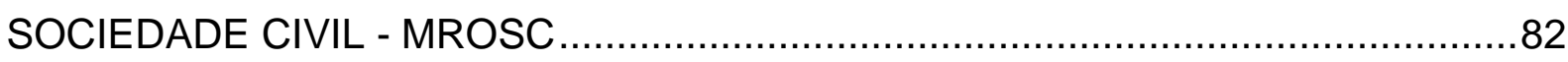

8 DESAFIOS DAS ORGANIZAÇÕES DA SOCIEDADE CIVIL NO BRASIL....84

8.1 ELEMENTOS CARACTERIZADORES DAS OSC COMO REQUISITO PARA

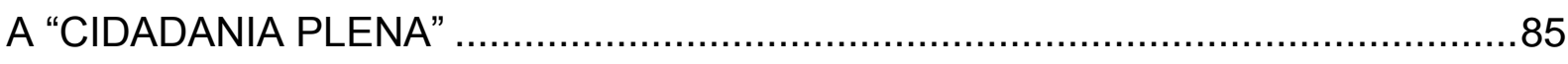

8.1.1 Análise de Caso: A questão da Remuneração de Dirigentes .........................89

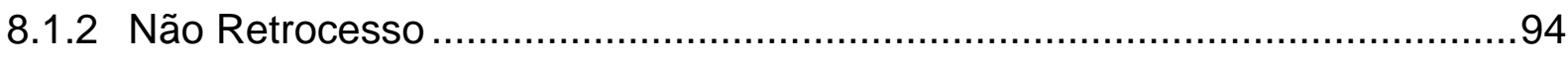

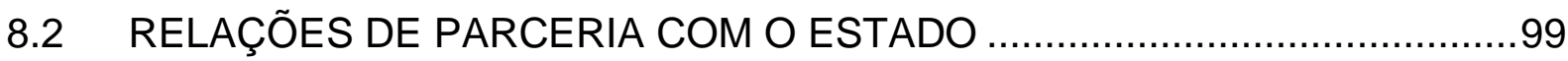

8.2.1 Regime Jurídico Aplicável às Relações de Parceria......................................99

8.2.2 Controle e as Prestações de Contas das Relações de Parceria ...................103

9 A LEI 13.019/2014 E A LIBERDADE DE ASSOCIAÇÃO DAS OSCs ........107

9.1 POLÍTICA NACIONAL DE FOMENTO E COLABORAÇÃO …....................107

9.2 OS MECANISMOS DE MODULAÇÃO PARA APLICAÇÃO DA LEI ..............114

10 CONSIDERAÇÕES FINAIS .........................................................117

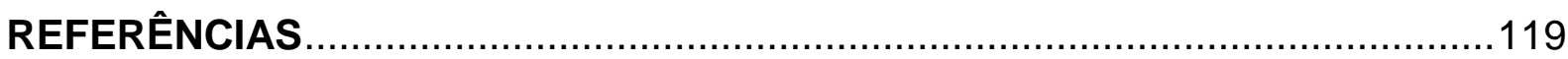




\section{INTRODUÇÃO}

Este trabalho se origina a partir da percepção de que o crescimento do chamado terceiro setor e a criação de mecanismos específicos de colaboração entre Estado e Organizações da Sociedade Civil - OSC, deram maior visibilidade à atuação destas organizações nos últimos anos, que passaram a receber também mais atenção como objeto de estudo pela academia, nas diferentes áreas do conhecimento.

A regulamentação pública (editada principalmente pelo Poder Executivo) se dedicou prioritariamente a estabelecer normas sobre o acesso a recursos públicos por essas entidades, como também as condições para execução financeira e controle dos gastos realizados em nome próprio, ou como gestoras de recursos públicos repassados pelo Poder Público.

Nossa pesquisa procurou analisar as normas relativas às organizações da sociedade civil no Brasil, a partir deste contexto, mas também considerando o direito fundamental de Liberdade de Associação, previsto na Constituição Federal de 1988 e em tratados internacionais dos quais o Brasil é signatário, desde a promulgação da Constituição de 1988. Buscamos identificar de que forma o direito de liberdade de associação e o direito de liberdade de auto-organização das associações se aplicam às organizações da sociedade civil brasileiras, analisando as normas que tratam das organizações da sociedade civil no Brasil, a fim de identificar os principais desafios a serem superados para uma adequada regulamentação das organizações da sociedade civil em nosso país.

Cumpre registrar que o presente trabalho foi desenvolvido num período em que ocorreram importantes mudanças no cenário relativo às OSC, que culminaram na aprovação de Lei 13.019/2014, que dispõe sobre normas gerais que tratam das parcerias entre Estado e OSC e cria a Política de Fomento e Colaboração.

Este fato resultou na maior aproximação neste estudo das matérias de Direitos Humanos e de Direito Administrativo, confirmando, também no que concerne o direito humano fundamental de liberdade de associação, a tendência de impactos no Direito Administrativo moderno para garantir os direitos fundamentais. 


\section{LIBERDADE DE ASSOCIAÇÃO E ORGANIZAÇÕES DA SOCIEDADE CIVIL}

Promulgada ao término de um período de repressão e ditadura militar, a Constituição Federal de 1988, também denominada "Constituição Cidadã", estabelece que o Estado brasileiro é um Estado Democrático de Direito, que tem a participação ativa da sociedade na gestão dos temas de interesse público como princípio. Nesse cenário, a participação das organizações da sociedade civil sem fins lucrativos é elemento de desenvolvimento nacional, tanto na perspectiva social como na econômica, na condição de componente essencial para a garantia do princípio da igualdade e para a construção da dignidade do cidadão.

O Estado brasileiro reconhece a relevância do envolvimento dos cidadãos nos processos e decisões que afetem aquilo que a todos pertence, ou seja, o que é público. Conforme o parágrafo único do art. 1․ do texto constitucional, "todo o poder emana do povo, que o exerce por meio de representantes eleitos ou diretamente, nos termos desta Constituição".

O sistema democrático inaugurado em 1988 congrega, ao mesmo tempo, um elemento representativo e outro participativo. A participação social das pessoas foi reconhecida como princípio e como verdadeira ferramenta necessária à manutenção do próprio Estado Democrático.

A opção do constituinte pelo Estado Democrático de Direito proporcionou as bases necessárias para que as organizações da sociedade civil brasileira assumissem papel de instituições aptas a contribuir para a formação de "uma sociedade fraterna, pluralista e sem preconceitos, fundada na harmonia social e comprometida na ordem interna e internacional, com a solução pacífica das controvérsias", conforme os termos no preâmbulo da nossa Constituição. Assim, o texto constitucional não apenas assegurou a liberdade de auto-organização das associações, mas criou mecanismos para evitar a interferência nessas entidades, prevendo expressamente a desnecessidade de autorização para sua criação e proibindo a interferência estatal em seu funcionamento (art. 5ํ, XVIII).

No plano dos direitos individuais, elencados no art. $5^{\circ}$, a Constituição Federal brasileira garante a plena liberdade de associação para fins lícitos e a liberdade de 
auto-organização das associações, proibindo a interferência estatal em seu funcionamento e garantindo a legitimidade das entidades associativas para representar seus filiados judicial ou extrajudicialmente, inclusive, por meio da impetração de mandado de segurança.

Art. $5^{\circ}$ Todos são iguais perante a lei, sem distinção de qualquer natureza, garantindo-se aos brasileiros e aos estrangeiros residentes no País a inviolabilidade do direito à vida, à liberdade, à igualdade, à segurança e à propriedade, nos termos seguintes:

$[\ldots]$

XVII - é plena a liberdade de associação para fins lícitos, vedada a de caráter paramilitar;

XVIII - a criação de associações e, na forma da lei, a de cooperativas independem de autorização, sendo vedada a interferência estatal em seu funcionamento;

XIX - as associações só poderão ser compulsoriamente dissolvidas ou ter suas atividades suspensas por decisão judicial, exigindo-se, no primeiro caso, o trânsito em julgado;

XX - ninguém poderá ser compelido a associar-se ou a permanecer associado;

$\mathrm{XXI}$ - as entidades associativas, quando expressamente autorizadas, têm legitimidade para representar seus filiados judicial ou extrajudicialmente; [...]

Ademais, reafirma a livre iniciativa como fundamento do Estado Democrático e da própria ordem econômica, cuja finalidade é assegurar a todos existência digna, conforme os ditames da justiça social (art. 170). A liberdade de associação possibilita às pessoas se unirem efetivamente, de forma voluntária, contratual e duradoura em torno de uma finalidade comum.

José Afonso da Silva ${ }^{1}$ afirma que "associação é toda coligação voluntária de algumas ou muitas pessoas físicas, por tempo longo, com o intuito de alcançar algum fim (lícito), sob direção unificante".

Este direito comporta a associação de pessoas para objetivos diversos, como a finalidade comercial, econômica, religiosa, sindical, entre outras. Em termos de proteção internacional dos direitos humanos, frequentemente, fala-se do tema a partir da perspectiva da liberdade de associação sindical.

No entanto, neste trabalho, nossa perspectiva no tratamento da liberdade de associação será aquela que interessa à compreensão dos desafios das

1 SILVA, José Afonso da. Curso de Direito Constitucional Positivo. 29. ed. São Paulo: Malheiros, 2007, p. 266. 
organizações da sociedade civil, as chamadas ONGs - as organizações não governamentais.

A liberdade de associação é prevista na Declaração Universal dos Direitos Humanos das Nações Unidas (ONU), de 1948, que assim estabelece em seu art. 20:

Artigo 20

I - Toda pessoa tem direito à liberdade de reunião e associação pacíficas

II - Ninguém pode ser obrigado a fazer parte de uma associação.

A liberdade de associação está também garantida no art. 22 do Pacto Internacional de Direitos Civis e Políticos, ratificado pelo Brasil por meio do Decreto no 592, de 6 de julho de 1992.

Art. 22

1. Toda pessoa terá o direito de associar-se livremente a outras, inclusive o direito de construir sindicatos e de a eles filiar-se, para a proteção de seus interesses.

2. O exercício desse direito estará sujeito apenas às restrições previstas em lei e que se façam necessárias, em uma sociedade democrática, no interesse da segurança nacional, da segurança e da ordem públicas, ou para proteger a saúde ou a moral públicas ou os direitos e liberdades das demais pessoas. O presente artigo não impedirá que se submeta a restrições legais o exercício desse direito por membros das forças armadas e da polícia.

3. Nenhuma das disposições do presente artigo permitirá que Estados Partes da Convenção de 1948 da Organização Internacional do Trabalho, relativa à liberdade sindical e à proteção do direito sindical, venham a adotar medidas legislativas que restrinjam ou aplicar a lei de maneira a restringir as garantias previstas na referida convenção.

A Convenção Americana de Direitos Humanos da Organização dos Estados Americanos (OEA), ratificada pelo Brasil, pelo Decreto ํㅜ 678, de 6 de novembro de 1992, no seu art. 16, também, dedica dispositivo específico para a garantia da Liberdade de Associação:

Artigo 16 - Liberdade de associação

1. Todas as pessoas têm o direito de associar-se livremente com fins ideológicos, religiosos, políticos, econômicos, trabalhistas, sociais, culturais, desportivos ou de qualquer outra natureza.

2. O exercício desse direito só pode estar sujeito às restrições previstas em lei e que se façam necessárias, em uma sociedade democrática, ao interesse da segurança nacional, da segurança e da ordem públicas, ou para proteger a saúde ou a moral públicas ou os direitos e as liberdades das demais pessoas. 
3. O presente artigo não impede a imposição de restrições legais, e mesmo a privação do exercício do direito de associação, aos membros das forças armadas e da polícia.

Esses tratados internacionais são reconhecidos também como direitos fundamentais, conforme art. 5, §2º da Constituição Federal ao estabelecer que "os direitos e garantias expressos nesta Constituição não excluem outros decorrentes do regime e dos princípios por ela adotados, ou dos tratados internacionais em que a República Federativa do Brasil seja parte".

\subsection{LIBERDADE DE ASSOCIAÇÃO COMO DIREITO INDIVIDUAL}

O texto constitucional expressamente trata da liberdade de associação e de reunião pacífica no plano dos direitos individuais (art. 5ํ, XVI e XVII), vedadas a ação de grupos armados, civis ou militares, contra a ordem constitucional e o Estado Democrático, considerado crime inafiançável e imprescritível (art. 5ํㅡ, XLIV).

Com o intuito de resguardar a autonomia e a independência das organizações da sociedade civil, assegurou o constituinte, às associações o pleno exercício de seu direito fundamental ao contraditório e à ampla defesa (art. 5o, LV), dispondo que eventual dissolução ou suspensão compulsória das atividades dependeria de decisão judicial transitada em julgado (art. 5으, XIX).

Em atinência à proibição da promoção da violência, há casos de grande repercussão pública envolvendo torcidas organizadas de times de futebol, exemplos de associações que tiveram suas atividades suspensas, ou compulsoriamente dissolvidas, em razão do desvio da finalidade original para promoção da violência, "perdendo a ideologia primitiva (incentivo a uma equipe esportiva) transformou-se em instituição organizada para difusão de pânico e terror em espetáculos desportivos [...]".2

Eis que a liberdade de associação, segundo o texto constitucional, revela-se através de quatro diferentes dimensões: a) o direito, em si, de criação das organizações associativas; (b) o direito de qualquer pessoa aderir, de forma

${ }^{2}$ TJ/SP, Ac. 3ํㅡㄹ Câm. Cív., ApCív. 102.023-4/3, rel. Des. Ênio Santarelli Zuliani, j.17.10.2000, in RT 786:163. 
voluntária, a uma associação, incorporando também a sua dimensão negativa, que diz respeito à liberdade de não se associar³; (c) o direito de qualquer pessoa de se desligar de uma associação, a qualquer tempo, visto que ninguém pode ser compelido a permanecer associado; e, por fim, (d) o direito dos associados de dissolverem espontaneamente a associação, uma vez que não se pode compelir uma associação a continuar existindo quando já não há mais o elemento comum que uniu os seus fundadores.

Sobre o direito de cada associação definir as próprias regras de seu funcionamento, vale mencionar o texto inicialmente publicado do novo Código Civil (Lei $\mathrm{n}$-10.406/02), que, em janeiro de 2002, trouxe uma série de novidades no funcionamento interno das associações. Criou a obrigatoriedade da existência de uma Assembleia Geral com competências privativas de eleger e destituir administradores, aprovar as contas e alterar o Estatuto Social, além de prever quórum específico para a tomada de determinadas decisões.

Tais inovações legais causaram polêmica por interferir diretamente na autogestão das entidades e resultaram em uma série de problemas práticos no modus operandi das associações.

Os principais entraves originários da alteração do Código Civil foram superados pela Lei 11.127/05, que alterou a redação original do Código Civil de 2002 para excluir dispositivos que determinavam quóruns específicos, a competência obrigatória da assembleia para exclusão de associados, aprovação de contas e eleição de dirigentes, além de outras alterações pontuais.

A alteração reduziu a esfera de interferência estatal na liberdade de autoorganização das associações, ao reconhecer a prevalência das regras próprias dessas entidades privadas, estabelecendo a soberania da Assembleia Geral para aprovar o estatuto social que melhor convier de maneira concreta à administração da entidade, para que esta estabeleça, de forma autônoma, a sua própria forma de funcionamento.

O tema foi ventilado pelo STF, em Ação Direta de Inconstitucionalidade (ADI), em que reconheceu a liberdade de associação e tratou da alegada violação contida

3 BRASIL. Supremo Tribunal Federal, ADI 2.054. traz no voto do relator Sepúlvida Pertence, divergência com relação à dimensão negativa se implícita nas demais constituições. 
na redação original do art. 59 do Código Civil de 2002, posteriormente alterada pela Lei $11.127 / 2005$, fazendo com que a ação perdesse o objeto ${ }^{4}$.

Um dos artigos alterados retirou a obrigatoriedade de que a Assembleia Geral elegesse diretamente os administradores da entidade e fosse o órgão responsável pela aprovação das contas. Contudo, o Código manteve a obrigatoriedade de existência de uma Assembleia Geral com competência exclusiva de deliberar sobre a exclusão de dirigente, mediante justa causa ${ }^{5}$.

A liberdade de associação foi ainda reconhecida pela Constituição como forma ou mecanismo de garantia de outros direitos. Nesse sentido, reconheceu às entidades associativas legitimidade para representarem seus filiados judicial ou extrajudicialmente, inclusive, por meio da impetração de mandado de segurança, com vistas à defesa dos interesses de seus membros ou associados (art. $5^{\circ}, \mathrm{XXI}$ e LXX).

Apesar de a liberdade de associação ser matéria de tratamento pela Constituição Federal, a jurisprudência abordando a matéria no STF não é vasta, haja vista que muitos dos problemas relacionados ao funcionamento interno das organizações da sociedade civil são resolvidos em nível administrativo, nos próprios registros civis de pessoa jurídica de cada localidade. Recorrer ao Judiciário é raro e aguardar que os casos cheguem ao Supremo Tribunal Federal costuma envolver custos elevados e longa espera de tempo para a solução das demandas.

\subsection{LIBERDADE DE ASSOCIAÇÃO COMO UMA LIBERDADE PÚBLICA}

A liberdade de associação é classificada como uma das liberdades públicas. ${ }^{6}$ Em conjunto com a liberdade de reunião - com a qual é tradicionalmente vinculada - compõem as principais espécies de liberdades públicas voltadas à ação coletiva, pois, ainda que tenha titularidade individual, para o seu exercício é necessário o exercício dessas liberdades por mais de um indivíduo.

\footnotetext{
${ }^{5}$ BRASIL. Supremo Tribunal Federal, RE 201.819. Relator: Min. Gilmar Mendes. Brasília, 11/10/2005.

6 PRUDENTE, Eunice Aparecida de Jesus. Direito à personalidade integral: cidadania plena. Tese (Doutorado em Direito) - Universidade de São Paulo. 1996, p.13.
} 
Na prática também se verifica correlação entres essas duas liberdades. Nas associações, em geral, ocorrem reuniões, sendo que essas últimas necessariamente exigem um elemento espacial: as pessoas unem-se num determinado local.

A respeito da relevância da liberdade de reunião e de associação para fins lícitos e da liberdade de expressão, já se pronunciou o Supremo Tribunal Federal, na Ação Declaratória de Inconstitucionalidade 1969/DF²:

\begin{abstract}
Ementa: AÇÃO DIRETA DE INCONSTITUCIONALIDADE. DECRETO 20.098/99, DO DISTRITO FEDERAL. LIBERDADE DE REUNIÃO E DE MANIFESTACÃO PÚBLICA. LIMITAÇÕES. OFENSA AO ART. 5ํ, XVI, DA CONSTITUIÇÃO FEDERAL. I. A liberdade de reunião e de associação para fins lícitos constitui uma das mais importantes conquistas da civilização, enquanto fundamento das modernas democracias políticas. II. A restrição ao direito de reunião estabelecida pelo Decreto distrital 20.098/99, a toda evidência, mostra-se inadequada, desnecessária e desproporcional quando confrontada com a vontade da Constituição (Wille zur Verfassung). III.Ação direta julgada procedente para declarar a inconstitucionalidade do Decreto distrital 20.098/99. (grifos nossos)
\end{abstract}

A liberdade de reunião nos remete à ideia de um encontro de pessoas organizado, mas, geralmente, não duradouro, e conforme bem salientado pelo Ministro Marco Aurélio, no voto que embasou a concessão de liminar na mesma ADI 1969/DF: “o direito de reunião previsto o inciso XVI está associado umbilicalmente a outro de maior importância em sociedades que se digam democráticas: o ligado à manifestação do pensamento" (grifos nossos)

Contudo o principal aspecto que diferencia a liberdade de reunião da liberdade de associação é o temporal, uma vez que a reunião é um mero fato, ao passo que a associação é mais duradoura no tempo, embora não dependa da sua existência formal como pessoa jurídica.

Para Fernando Dias Menezes de Almeida $^{8}$, as liberdades públicas são tratadas tradicionalmente como direitos individuais, com relação ao qual o Estado e os outros indivíduos mantêm uma esfera de não ingerência, constituindo o que a

\footnotetext{
7 BRASIL. Supremo Tribunal Federal, ADI 1969/DF. Relator: Min. Ricardo Lewandowski. Brasília, 28/06/2007.

${ }^{8}$ Conforme MENEZES DE ALMEIDA, Fernando. Liberdades públicas de ação coletiva: a posição do Supremo Tribunal Federal analisada à luz do Direito internacional dos direitos humanos. In: AMARAL JÚNIOR, Alberto do; JUBILUT, Liliana Lyra (Org.). O STF e o Direito internacional dos direitos humanos. São Paulo: Quartier Latin, 2009. p. 190-209.
} 
doutrina clássica de direitos humanos classificou de "direitos de primeira geração", aos quais, depois, incorporam-se os "direitos de segunda geração" (econômicos e sociais), que possibilitam exigir contraprestações do Estado e que, ulteriormente, soma-se aos direitos de terceira geração, aqueles direitos da fraternidade, além dos direitos humanos de quarta geração, que seriam os direitos de natureza difusa.

Como não faz sentido pensar no exercício de direitos por um indivíduo senão em sociedade, a classificação geracional de direitos humanos supramencionada, foi revista a partir de uma perspectiva que os considera de forma indivisível, interdependente e inter-relacionada.

A prática da liberdade associativa possibilita não apenas o exercício da cidadania (reconhecida pela Constituição de 1988 como fundamento do Estado Democrático de Direito) e a conquista de direitos, como também estimula o fortalecimento do regime democrático e da democracia participativa.

Para efetivo exercício do direito de liberdade de associação, é necessário que outros direitos e liberdades sejam garantidos. Nessa direção, a Constituição prevê a liberdade de manifestação do pensamento (art. 5ํ, IV) e de expressão (da atividade intelectual, artística, científica e de comunicação - art. 5으. IX), a vedação à censura de natureza política, ideológica e artística, tendo sido assegurada a liberdade de manifestação do pensamento, criação, expressão e informação sob qualquer forma, processo ou veículo (art. 220, §º).

A liberdade sindical também foi assegurada constitucionalmente. A fundação de sindicatos independe de autorização estatal, e é vedado ao Poder Público qualquer interferência ou intervenção nas organizações sindicais. O Supremo Tribunal Federal fundamenta no princípio da liberdade de associação o reconhecimento das confederações sindicais como entidades de coordenação das federações sindicais, que, conquanto não integrem a hierarquia das entidades sindicais, "são admitidas no nosso sistema jurídico tão só pelo princípio da liberdade de associação". 9

Na mesma direção, garantiu-se de forma equânime a todos os trabalhadores, inclusive aos que atuam fora da zona urbana, em áreas rurais e/ou em colônias de

\footnotetext{
${ }^{9}$ BRASIL. Supremo Tribunal Federal, ADI 444. Relator: Min. Moreora Alves. Brasília, 14/06/1991.
} 
pescadores, o direito de decidir sobre sua adesão ou não ao respectivo órgão representativo da classe (art. $8^{\circ}$, $\mathrm{V}$ e parágrafo único). O texto constitucional prevê o direito de greve não apenas enquanto um direito social em si mesmo, mas como verdadeira garantia ou ferramenta necessária à proteção e promoção de outros direitos sociais assegurados (art. 9ํ).

Os direitos de participação política, direta e indireta, estão previstos no art. 25 do Pacto Internacional dos Direitos Civis e Políticos e no art. 23 da Convenção Americana de Direitos Humanos, que, pela cláusula de abertura constante do art. 5을 $\S 2^{\circ}$, da Constituição Federal, são reconhecidos também como direitos fundamentais. A soberania popular, que também revela uma das faces da nossa democracia participativa, manifesta-se através do sufrágio universal e do voto direto e secreto, com igual valor para todos.

No que se refere à interação com o direito internacional dos direitos humanos, a Constituição de 1988 prevê que o Brasil se submete à jurisdição de Tribunal Penal

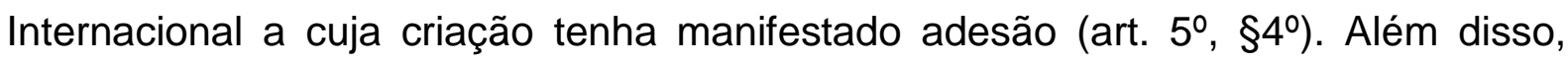
confere o status de norma constitucional aos tratados internacionais de direitos humanos internalizados no ordenamento jurídico brasileiro conforme quórum especial ali previsto. O primeiro tratado de Direitos Humanos aprovado com o quórum estabelecido no art. 5으, §3o, incluído pela Emenda Constitucional ㄲo45/04 (ou seja, em cada um das Casas do Congresso Nacional em dois turnos, por 3/5 dos votos dos respectivos membros) foi a Convenção dos Direitos das Pessoas com Deficiência ${ }^{10}$.

Com relação a outras organizações e grupos específicos, a Constituição assegura o livre exercício dos cultos religiosos, estabelecendo ainda proteção aos locais de culto e às suas liturgias (art. 5, VI). Na mesma direção, institui vedação expressa quanto à instituição de tributos sobre os templos de qualquer culto (art. 150, VI, b), garante a prestação de assistência religiosa nas entidades civis e militares de internação coletiva (art. 5, VII) e que, por motivo de crença religiosa ou convicção filosófica ou política, ninguém será privado de direitos (art. 5, VIII). ${ }^{11}$

\footnotetext{
${ }^{10}$ LOPES, Laís Vanessa Carvalho de Figueirêdo, Convenção sobre os Direitos das Pessoas com Deficiência da ONU, seu Protocolo Facultativo e a Acessibilidade - Dissertação apresentada à Banca Examinadora da Pontifícia Universidade Católica de São Paulo - São Paulo, 2009, p.72

${ }_{11}$ BALEEIRO, Aliomar. Direito Tributário Brasileiro. 10. ed. Rio de Janeiro: Forense, 1996.
} 
Sobre as comunidades indígenas e suas organizações, previu a Constituição a sua legitimidade para ingressar em juízo em defesa de seus direitos e interesses, lembrando que estas podem se constituir como associações, ou fundações.

Relativamente aos princípios que dizem respeito ou afetam a existência das OSCs, merecem destaque alguns dos instrumentos de participação cidadã que o legislador constituinte reconheceu. É o caso da garantia de iniciativa de lei aos cidadãos (art. 61), por meio da apresentação à Câmara dos Deputados de projeto de lei subscrito por no mínimo $1 \%$ do eleitorado nacional, distribuído em pelo menos cinco estados, com não menos de três décimos por cento dos eleitores de cada um deles (art. 61, $\$ 2^{\circ}$ ).

A legitimidade conferida a qualquer cidadão para "propor ação popular que vise a anular ato lesivo ao patrimônio público ou de entidade de que o Estado participe, à moralidade administrativa, ao meio ambiente e ao patrimônio histórico e cultural" (art. 5ำ, LXXIII), como também a legitimidade conferida às entidades associativas para ingressar com Ação Civil Pública, instrumento que encontra previsão constitucional e em legislação própria ${ }^{12}$, e que visa à proteção do meio ambiente, do consumidor, à ordem econômica, à livre concorrência ou ao patrimônio artístico, estético, histórico, turístico e paisagístico, dentre outros interesses difusos e coletivos.

A Constituição prevê também algumas ações que permitem o controle da constitucionalidade das leis brasileiras: a Ação direta de inconstitucionalidade (ADI), que pode ser proposta por autoridades políticas, por partido político com representação no Congresso Nacional, confederação sindical ou OSC representativas de entidades de classe de âmbito nacional; e Arguição de descumprimento de preceito fundamental (APDF), criada pela Lei $\mathrm{n}-9.882 / 99$, que tem por finalidade evitar ou reparar lesão a preceito fundamental, podendo ser objeto do pedido atos do poder público, atos privados, atos normativos, atos administrativos e atos jurisdicionais, podem ser propostas pelos mesmos legitimados a propor a ADI.

12 Lei Federal n. 7.347, de 24 de julho de 1985. Disponível em: <http://www.planalto.gov.br/ccivil_03/leis//7347orig.htm>. Acesso em: 29 nov. 2013. 
O Conselho da República (art. 89) e o Conselho de Defesa Nacional (art. 90), por sua vez, são órgãos de consulta do Presidente da República, sendo o primeiro dotado da competência de pronunciar-se sobre casos de intervenção federal, estado de sítio, estado de defesa e outras questões relevantes; e o segundo atua nos assuntos que dizem respeito à soberania nacional e à defesa do Estado Democrático (art. 136).

Merece registro a previsão de participação de entidades da sociedade civil em audiências públicas a serem realizadas por comissões permanentes ou temporárias do Congresso Nacional ou de suas Casas (Câmara dos Deputados e Senado Federal) (art. 58, $\S 2^{\circ}$ ) e os mecanismos diretos de participação da população (art. 14), como o sufrágio universal - pelo voto direto e secreto, com valor igual para todos, e pela realização de plebiscito, referendo e projetos de lei de iniciativa popular.

Além dos referidos mecanismos, a Constituição assegura a participação da sociedade e das suas organizações representativas, na definição e no controle social de políticas públicas específicas, notadamente, nas políticas sociais por meio de representação em Conselhos. As passagens mais relevantes da previsão constitucional de participação e controle social por organizações da sociedade civil são relativas ao planejamento municipal (art. 29, XII); direitos dos usuários dos serviços públicos (art. 37, §39); seguridade social (art. 194, parágrafo único, VII); saúde (art. 198, III - CF); educação (art. 205); proteção do patrimônio cultural brasileiro (art. 216, $\$ 1$ 9); e do meio ambiente (art. 225); assistência social (art. 204), criança e do adolescente (art. 227, $\$ 7^{\text {9) }}$.

Esses Conselhos hoje no Brasil alcançaram um grande número de políticas nas mais diversas áreas, havendo expressiva representação em nível municipal, estadual e federal. Apesar da existência dessas instâncias e de haver financiamento público para subsidiar as reuniões de Conselheiros, há muita discussão em torno da legitimidade e da efetividade da participação, em que pese haver reconhecimento geral de que, mesmo sujeito a críticas, o mecanismo contribui para a participação, em que pese a necessidade de aperfeiçoar o modelo.

Para Boaventura de Souza Santos, em determinados momentos, Estado e sociedade civil podem ser considerados domínio um do outro: "Nas três últimas 
décadas a distinção entre Estado e sociedade civil, longe de ser um pressuposto da luta política moderna, é o resultado dela. A tensão deixa de ser, assim, entre Estado e sociedade civil, para ser entre interesses e grupos sociais que se reproduzem melhor sob a forma de Estado e interesses e grupos sociais que se reproduzem melhor sob a forma de sociedade civil $^{13}$."

Essa tensão tornaria problemático o âmbito efetivo de atuação dos direitos humanos. O autor cita que historicamente os direitos humanos de primeira geração (civis e políticos) nasceram de uma luta da sociedade civil, ao passo que os de segunda e terceira, vieram como resultado de um Estado atuante, momento em que a sociedade civil passa a ser vista como inerentemente problemática e carente de crescente intervenção estatal. Nesse contexto, uma sociedade civil forte seria reflexo de um Estado forte. Todavia, para o autor, este cenário muda com o neoliberalismo, quando o Estado passou a ser fonte de infinitos problemas e a sociedade civil se torna oposta ao Estado, sendo uma sociedade civil forte a exigir de um Estado fraco.

Neste ponto é importante frisar o caráter privado das OSC e o fato de que a sua atuação pode ser dar sem qualquer colaboração com o Estado, como entidades típicas de uma sociedade civil organizada que atua de forma crítica e independente, fazendo pressão pública e exercendo o controle social das atividades governamentais.

Recentemente, a disputa travada entre Governo e Congresso Nacional em torno do Decreto 8.243/2014, que organiza a Política Nacional da Participação Social, dá a dimensão do alcance e da importância em se fazer a discussão sobre participação social e o papel das organizações da sociedade civil no atual contexto de nossa democracia.

13 SANTOS, Boaventura de Souza. "Para uma Concepção Intercultural dos Direitos Humanos". In: SARMENTO, Daniel; Ikawa, Daniela e PIOVESAN, Flávia (Orgs.). Igualdade, Diferença e Direitos Humanos. Rio de Janeiro: Editora Lumen Juris, 2008, p. 29. 


\subsection{LIBERDADE DE ASSOCIAÇÃO COMO UMA LIBERDADE PÚBLICA VOLTADA À COOPERAÇÃO COM O ESTADO}

Também merece destaque o fundamento constitucional para que essa participação transcenda às ações de controle social e do monitoramento das políticas públicas, para que as OSC passem a compartilhar com o Estado responsabilidades na efetiva execução de planos de ação no âmbito de políticas públicas.

A própria jurisprudência do Supremo Tribunal Federal reconhece a dimensão constitucional dessa participação por meio da execução direta de ações em colaboração com o Estado, inclusive com a possibilidade de financiamento público e prestação de serviços de relevância pública pelas OSC, a exemplo do voto proferido pelo Ministro Carlos Ayres Britto, do STF, em sessão de julgamento da Ação Direta de Inconstitucionalidade no 1923:

[...] 21. Já no que toca às atividades de senhorio misto, serão elas de natureza pública, se prestadas pelo próprio Estado, ou em parceria com o setor privado. Quanto à possibilidade de destinação de recursos públicos às entidades privadas, exercentes de atividades de relevância pública, também não vacila a Constituição Federal, ainda que imponha a observância de certos requisitos.

[...]

Em suma, o papel do Estado na prestação de certas atividades, dentre as quais os serviços públicos, é o de protagonista-mor ou agente central. [...] os particulares podem desempenhar atividades que também correspondem a deveres do Estado, mas não são exclusivamente públicas [...] atividades predispostas a uma protagonizarão conjunta do Estado e da sociedade civil [...] O que a Magna Carta admite e até mesmo estimula, agora sim, é a colaboração entre particulares e o Poder Público. [...] Conforme visto, a Magna Carta franqueia à iniciativa privada a prestação de vários serviços de relevância pública e permite (até mesmo determina) que o Poder Público fomente essas atividades, inclusive mediante transpasse de recursos públicos. (Grifos nossos).

Apesar da ADI em questão tratar especificamente da Lei Federal das Organizações Sociais (Lei 9637/98), o fundamento constitucional das parcerias trazidas no voto alcança todas as OSC.

A atuação em áreas específicas de responsabilidade estatal é prevista de forma clara na Constituição Estatal, consagrada pelo princípio da livre iniciativa. Particularmente nas políticas públicas de educação e de saúde, o texto 
constitucional não vacila ao prever o papel das organizações da sociedade civil sem fins lucrativos que atuam nessas áreas, destacando-se o teor dos arts. 199 e 205:

Art. 199. A assistência à saúde é livre à iniciativa privada.

$\S 1^{\circ}$. As instituições privadas poderão participar de forma complementar do sistema único de saúde, segundo diretrizes deste, mediante contrato de direito público ou convênio, tendo preferência as entidades filantrópicas e as sem fins lucrativos.

Art. 205. A educação, direito de todos e dever do Estado e da família, será promovida e incentivada com a colaboração da sociedade, visando ao pleno desenvolvimento da pessoa, seu preparo para o exercício da cidadania e sua qualificação para o trabalho. (Grifos nossos).

Nas áreas da cultura e do meio ambiente, a Constituição também trata com protagonismo o papel da sociedade voltado à atuação em colaboração com o Estado para desenvolvimento de iniciativas relativas à promoção dos direitos e preservação dos patrimônios:

\footnotetext{
Art. 216. [...]

$\S 1^{\circ}$. O poder público, com a colaboração da comunidade, promoverá e protegerá o patrimônio cultural brasileiro, por meio de inventários, registros, vigilância, tombamento e desapropriação, e de outras formas de acautelamento e preservação.

Art. 225. Todos têm direito ao meio ambiente ecologicamente equilibrado, bem de uso comum do povo e essencial à sadia qualidade de vida, impondo-se ao poder público e à coletividade o dever de defendê-lo e preservá-lo para as presentes e futuras gerações. (Grifos nossos).
}

Ao tratar da proteção à criança e ao adolescente, a Constituição, assim como faz nas áreas da saúde e da educação, prevê a colaboração do Estado com organizações da sociedade civil e estabelece a obrigação do Estado realizar ações voltadas à promoção do financiamento próprio e criação de estímulos e subsídios para ações relativas aos direitos das crianças e dos adolescentes.

Art. 227. É dever da família, da sociedade e do Estado assegurar à criança e ao adolescente, com absoluta prioridade, 0 direito à vida, à saúde, à alimentação, à educação, ao lazer, à profissionalização, à cultura, à dignidade, ao respeito, à liberdade e à convivência familiar e comunitária, além de colocá-los a salvo de toda forma de negligência, discriminação, exploração, violência, crueldade e opressão. 
$\S 1^{\circ}$. O Estado promoverá programas de assistência integral à saúde da criança e do adolescente, admitida a participação de entidades não governamentais e obedecendo aos seguintes preceitos:

[...]

§3ํ. O direito a proteção especial abrangerá os seguintes aspectos:

$[\ldots]$

VI - estímulo do poder público, através de assistência jurídica, incentivos fiscais e subsídios, nos termos da lei, ao acolhimento, sob a forma de guarda, de criança ou adolescente órfão ou abandonado; [...](Grifos nossos).

A colaboração entre Estado e organizações da sociedade civil é prática histórica e data dos tempos da colonização do Brasil. As Santas Casas de Misericórdia são tidas como as primeiras entidades do terceiro setor a receberem apoio estatal para desenvolvimento de suas atividades.

Podemos, assim, afirmar que é dever constitucional do Estado brasileiro se relacionar com as organizações da sociedade civil garantindo sua liberdade de existir, agir e se manifestar; como também criando espaços públicos para a prática da cidadania e investimento de recursos financeiros na difusão das boas iniciativas das OSC que contribuam para o desenvolvimento da sociedade.

Esta dimensão de financiamento público refere-se ao dever do Estado de investir (direta ou indiretamente, inclusive por meio de incentivos fiscais ou mecanismos de desoneração e simplificação) na existência e manutenção de organizações essenciais para a democracia, bem como na possibilidade de realizar as chamadas relações de contratualização, ou seja, celebrar com essas organizações instrumentos contratuais de prestação de serviços ou de colaboração, para desempenho de atividades de interesse mútuo.

No campo dos princípios que diretamente interferem na existência e atuação das OSC, merecem destaque as chamadas limitações constitucionais impostas ao poder de tributar. Estabeleceu a Constituição de 1988 expressa vedação à instituição de tributos, ou seja, verdadeira imunidade constitucional sobre o patrimônio, a renda ou serviços (relacionados às finalidades essenciais) dos partidos políticos, inclusive suas fundações, das entidades sindicais dos trabalhadores e das instituições de educação e de assistência social, sem fins lucrativos (art. 150, VI, c), imunidade esta, todavia, condicionada ao atendimento dos requisitos dispostos na legislação tributária. 
A imunidade constitucional conferida às entidades beneficentes de assistência social em relação ao recolhimento da contribuição para a seguridade social (art. 195, $\left.\S^{\circ}{ }^{\circ}\right)$ reforça ainda mais a proposta do constituinte de que a execução de atividades na área das políticas sociais, especialmente as de saúde, educação e assistência social, oferecidas com gratuidade à população, contassem com financiamento estatal para a sua execução por organizações privadas sem fins lucrativos.

Em que pese o amplo reconhecimento constitucional da liberdade de associação, como direito individual, como direito de ação coletiva e, nessa perspectiva, a legitimidade para demandar apoio público para atuar na execução de atividades de relevância pública, nem sempre ocorre na prática o respeito à liberdade de associação acontece.

Rodrigo Xavier Leonardo, em sua tese de doutoramento sobre as associações, faz uma minuciosa descrição histórica das Constituições brasileiras com relação ao tratamento dispensado ao direito de liberdade de associação, por meio do qual pôde concluir pela total desconexão entre o direito previsto no texto da norma (formal) e a prática institucionalizada (material), que lhe permitiu afirmar: ${ }^{14}$

\begin{abstract}
A investigação sobre as associações na história constitucional brasileira permite alcançar conclusões impressionantes. Se, por um lado, a proteção da liberdade de associação é dita e repetida nas diversas constituições brasileiras (plano meramente normativo), por outro lado, o efetivo exercício dessa liberdade nunca foi incentivado, nem tampouco garantido.

Pode-se concluir por uma desconexão entre o histórico programa constitucional $e$ as práticas efetivas de poder: 0 programa constitucional de liberdade de associação nunca passou de um mero programa, pelo menos até 1988. (Grifos nossos).
\end{abstract}

Como mencionado, nossa Constituição estabelece a plena liberdade de associação e elege as organizações da sociedade civil como sujeitos específicos a serem considerados no exercício desses direitos, tendo em vista a efetiva participação social.

Diante das inegáveis tensões que envolvem as relações entre organizações da sociedade civil e Estado e da ampliação proporcionada à atuação dessas entidades pela Constituição Federal de 1988, este trabalho buscará avaliar a

${ }^{14}$ LEONARDO, Rodrigo Xavier. As Associações em Sentido Estrito no Direito Privado. 2007. Tese (Doutorado em Direito) - Universidade de São Paulo, São Paulo, 2007. 
legislação geral aplicável às Organizações da Sociedade Civil brasileiras sob a perspectiva da liberdade de associação, com especial interesse nas normas (e práticas) relacionadas ao financiamento público de projetos de interesse comum entre a Administração pública e essas entidades.

Antes, todavia, vale situar o tema da liberdade de associação das OSC na América Latina e das OSC no contexto internacional. 


\section{CONTEXTO INTERNACIONAL}

\subsection{NOTAS SOBRE O DIREITO DE LIBERDADE DE ASSOCIAÇÃO NA AMÉRICA LATINA}

De modo geral, as Constituições da região da América Latina reconhecem a liberdade de associação e de reunião, o direito à liberdade de opinião e de expressão, liberdade de religião, direito à informação, entre outros direitos civis e políticos fundamentais de cidadania.

Recentemente, a Mesa de Articulação da América Latina e do Caribe e seus aliados do sul, grupo que congrega plataformas, associações e redes nacionais de OSC de vários países latino-americanos desenvolveu, com apoio da União Europeia, um extenso projeto intitulado "Mesa de Articulação de ALC e seus aliados do sul aumentam sua capacidade de incidência e diálogo com governos e setor privado", com o objetivo de diagnosticar a situação e promover, a partir do desenvolvimento de capacidades e políticas para a sustentabilidade, um ambiente propício à atuação das $\mathrm{OSC}$ da região.

Nesse sentido, foi elaborado um Estudo Regional da America Latina ${ }^{15}$ baseado em um minucioso trabalho coletivo de coleta e análise de informações e do esforço técnico conjunto de seleto grupo de consultores especializados nos respectivos países, realizado ao final de 2013 para o Projeto "Mesa de Articulação da ALC e seus aliados do sul aumentam sua capacidade de incidência e diálogo com governos e setor privado, e da sua posterior compilação em três relatórios subregionais: (i) do Cone Sul e Brasil ${ }^{16}$, que abarca a análise dos marcos regulatórios de Argentina, Brasil, Chile, Paraguai e Uruguai - elaborado por Felipe Viveros (Acción - Asociación Chilena de Organismos no Gubernamentales); (ii) da Região

\footnotetext{
${ }^{15}$ STORTO, Paula Raccanello. Marcos Jurídicos das Organizações da Sociedade Civil na América Latina. Documento elaborado para o Proyecto Regional Mesa de Articulación de America Latina y Caribe y sus Aliados del Sur. São Paulo, 2014. Disponível em http://mesadearticulacion.org/wpcontent/uploads/2015/02/Estudio-Marcos-Regulatorios-de-las-OSC.pdf

${ }^{16}$ VIVEROS, Felipe. "Sintesís Comparativa: Marcos Jurídicos de las Organizaciones de la Sociedad Civil en los Paises del Cono Sur e Brasil", Asociación Chilena de Organismos No Gubernamentales ACCIÓN, documento preparado para el Proyecto Regional Mesa de Articulación de América Latina y el Caribe y sus Aliados del Sur, Santiago, 2014.
} 
Andina $^{17}$, composto por Bolívia, Colômbia, Equador, Peru e Venezuela - elaborado por Luis Castillo Paulino (Asociación Nacional de Centros de Investigación, Promoción Social y Desarollo, ANC - Peru); e (iii) da América Central e México ${ }^{18}$, que estuda a legislação do México, Guatemala, Honduras, El Salvador e Nicarágua, elaborado por Patricia Lucki (Fundación para el Desarollo de la Innovación de Centroamerica).

Segundo informações constantes nos relatórios elaborados no referido Proyecto Regional Mesa de Articulación de America Latina y el Caribe y sus Aliados del Sur, todas as Constituições da região reconhecem a liberdade de associação como um dos direitos políticos fundamentais de cidadania, possibilitando sua proteção pelos tratados internacionais de direitos humanos, cuja vigência, em cada local, depende das normas próprias de recepção jurídica no direito interno.

Conforme assinalado no Relatório da Região Andina no Projeto da Mesa de Articulação, em alguns países, o direito constitucional de associação nasceu historicamente ligado ao direito de reunião. Mais tarde, em alguns países, estes dois direitos foram separados, constituindo-se o direito de associação como uma natureza vinculativa de direito, expresso na reunião de indivíduos com interesses comuns e fins específicos. Ao mesmo tempo, os direitos constitucionais de liberdade de expressão, acesso à informação pública e participação evoluíram em suas expressões atuais, especialmente, no século XX.

Assim como ocorre na Constituição brasileira, as Constituições dos países da região latino-americana garantem também outros direitos fundamentais que permitem o desempenho da sociedade civil e suas organizações, incluindo as liberdades de consciência, expressão e opinião, reunião, o direito de ser informado, para obter informações e elaborar relatórios, entre outros.

De acordo com a análise de Felipe Viveros, autor do Relatório da Sub-Região do Cone-Sul e Brasil, os textos das Constituições dos países estudados podem parecer um conjunto formal de dados, mas representam um considerável avanço

17 PAULINO, Luis Castillo; Huaman, Josefina. "Estudio sobre los Marcos Jurídicos de las Organizaciones no Gubernamentales een la Región Andina”, Asociación Nacional de Centros de Investigación, Promoción Social y Desarollo, ANC - Peru, Lima, 2014.

18 LUCKI, Patricia. "Marcos Jurídicos de la Participación Cuidadana y las Organizaciones no Gubernamentales en México, Guatemala, Honduras, El Salvador y Nicaragua”, Fundación para el Desarollo de la Innovación de Centroamerica. Guatemala, 2014. 
com relação à realidade de alguns anos, quando a região se caracterizava pelos regimes autoritários e suas normas típicas, que restringiam ou até mesmo suspendiam os direitos fundamentais das pessoas, inclusive aqueles relacionados às organizações sociais e seus líderes.

Algumas situações chamam a atenção em países que, apesar de preverem de forma ampla a liberdade de associação em suas cartas constitucionais, na prática condicionam a criação ou o exercício de direitos por essas entidades a autorizações administrativas ou legislativas, estabelecendo controle prévio à criação de entidades incompatível com a liberdade assegurada.

A Constituição da Nicarágua, por exemplo, contém disposição que a distingue de todas as demais, pois concede ao Congresso Nacional a competência de outorgar personalidade jurídica às associações civis, conforme redação do 138 , $\S 5^{0^{019}}$.

As Constituições latino-americanas são geralmente baseadas em princípios, ou seja, estabelecem normas gerais de direito que devem ser respeitadas e são necessárias para a aprovação e o desenvolvimento de leis secundárias. É através destas leis que normalmente se verificam eventuais promoções ou restrições do exercício dos direitos fundamentais consagrados na Constituição.

Cabe à Corte Interamericana de Direitos Humanos analisar casos de violações desses direitos após encerrada a jurisdição nacional dos países membros, com base no Pacto de San José da Costa Rica, da qual o Brasil é signatário. Vale mencionar que a Corte Interamericana já se manifestou no caso Escher e outros vs. Brasil $^{20}$, no sentido de que diferenciar os direitos de liberdade de associação e liberdade de reunião, estabelecendo que, diferentemente da liberdade de associação, o direito de reunião não implica necessariamente a criação ou participação em uma organização, mas pode manifestar-se em uma união esporádica ou congregação para perseguir fins pacíficos. A liberdade de associação pressupõe o direito de reunião, que se caracteriza por habilitar as pessoas para criar

\footnotetext{
${ }^{19}$ Art. 138. Son atribuciones de la Asamblea Nacional: (...) 5) Otorgar y cancelar la personalidad jurídica a las asociaciones civiles.

${ }^{20}$ Caso Escher e outros vs. Brasil, Sentença da Corte Interamericana de Direitos Humanos 6 de julho de 2009.
} 
ou participar de organizações com o objetivo de atuar coletivamente na consecução dos mais diversos fins, sempre e quando estes sejam legítimos.

Digno de nota também o caso Lopes Mendoza vs. Venezuela, que discutiu a declaração de inelegibilidade de Leopoldo Lopez Mendoza, então principal adversário de Hugo Chávez, em razão de decisão de tribunal administrativo venezuelano que a condenou pela irregularidade de repasses de recursos realizados pela empresa Petróleos de Venezuela S.A. ("PDVSA") para a Associação Civil "Primero Justicia", da qual López Mendoza havia sido um dos fundadores, durante o período em que sua mãe exercia a Gerência de Relações Públicas da PDVSA ${ }^{21}$. Aqui não se faz qualquer avaliação acerca do mérito da condenação administrativa imposta a Lopes Mendonza, mas apenas o registro do fato de que uma das condenações que resultou na declaração de inelegibilidade de Lopes Mendoza decorre de relações de financiamento público a OSC.

Já a Guatemala, Honduras, El Salvador, Nicarágua, Belize, Costa Rica, Panamá e República Dominicana, fazem parte do Sistema de Integração CentroAmericana $(\operatorname{SICA})^{22}$, no qual há também a possibilidade de discussão na Corte Centro-Americana de Justiça.

No que se refere à participação política, as Constituições da região da América Latina a reconhecem de modo geral como forma legítima dos cidadãos atuarem nos assuntos públicos. A maior parte dos países também dispõe de leis nacionais que estabelecem a organização da participação institucional.

Da mesma forma, a participação política é garantida pelos instrumentos internacionais de direitos humanos ratificados e vigentes na maior parte dos países da região, previstos no art. 23 do Pacto Internacional de Direitos Civis e Políticos e no art. 25 da Convenção Americana de Direitos Humanos.

Os relatórios mencionam o aumento dos instrumentos institucionais de participação cidadã na região latino-americana, seja por meio de mecanismos de

${ }^{21}$ Caso LÓPEZ MENDOZA v. VENEZUELA - Corte Interamericana de Direitos Humanos

${ }^{22}$ O Protocolo de Tegucigalpa, de 1991, que cria a SICA prevê, um Comitê Consultivo definido como "o órgão da sociedade civil independente e autônoma, organizada para reforçar a integração, o desenvolvimento e a democracia na América Central", devendo "promover a participação ativa da sociedade civil, de modo que o processo de integração responde eficazmente às realidades, necessidades e interesses da população da região", devendo para tanto guiar-se pelos princípios da regionalidade, representação, participação, autonomia, solidariedade, e equidade. 
democracia direta, como também dos mecanismos indiretos de consulta e deliberação (conselhos, comitês, audiências públicas, auditorias sociais, planos comunitários e orçamento participativo).

Nessa atuação participativa, as principais práticas relatadas na região são ligadas à participação em nível local, o controle social e a fiscalização das contas públicas, acesso à informação, atuação judicial em defesa do interesse público, articulações com o Estado para atuação em políticas públicas e as chamadas iniciativas independentes.

Há relatos do que chamam de "instrumentos de democracia direta nas denominadas zonas libertadas do capitalismo", que seriam grupos sociais com moedas locais e alguma independência do mercado. Apesar de pontuais, são formas políticas de participação autônoma e independente da sociedade na configuração de formas alternativas de arranjos sociais e econômicos.

A participação social não se limita aos espaços previstos. Participação pressupõe liberdade para criação de alternativas e espaços para a mudança das relações de poder, incidência nos assuntos relativos não apenas a políticas sociais, mas também ao modelo de desenvolvimento econômico, em espaços informais, com articulação com toda a sociedade, incluindo as universidades, os sindicatos, os intelectuais e outras organizações e lideranças comprometidas com o desenvolvimento da democracia.

\subsection{AS OSC NO CONTEXTO INTERNACIONAL}

É claro que a previsão formal no texto da Constituição dos países da região não é suficiente para garantir que não haja excessos, ameaças ou repressão pelos Estados às OSC, que se caracterizem como violações aos seus direitos. Todavia a sua identificação depende da observação atenta das realidades locais, sendo certo que, uma vez caracterizada violação e/ou falha na observância desses direitos pelos países, é possível acionar as Cortes Internacionais de Direitos Humanos para denunciá-las. 
As OSC atuam, não apenas nos países em que estão constituídas, mas como legítimos sujeitos de direito internacional ${ }^{23}$, propiciando a integração da população dos diferentes países nos temas relacionados ao desenvolvimento, ciência, ajuda humanitária, questões ambientais e climáticas, combate à fome, luta contra a corrupção e que proporcionam a sua participação na esfera internacional, inclusive em alguns casos, com assento e representação junto a organismos internacionais.

Apesar do reconhecimento histórico e da relevante função social que desempenham, a situação hoje nem sempre tem se mostrado favorável ao fomento e à continuidade do seu trabalho.

Entraves políticos, "clientelismos", arbitrariedades legislativas, discricionariedade estatal, desconfiança e generalização são alguns dos problemas enfrentados pelas OSC nos dias atuais. Quando buscamos explicar as razões para este fenômeno bastante recente alguns fatores despontam.

Um deles é a insuficiência de mecanismos tradicionais de representatividade das pessoas na política. As Organizações da Sociedade Civil (na América Latina, especialmente durante as ditaduras militares), foram eleitas por parcela da sociedade politicamente ativa como espaços alternativos para participação política. No entanto, com a redemocratização e a incorporação de mecanismos de consulta e participação das OSC no processo de tomada de decisão política, estas passaram a ser percebidas como instituições formais de participação, muitas vezes, burocráticas e limitadas. $O$ desinteresse dos jovens pelos partidos políticos e processos eleitorais seria parte deste mesmo fenômeno. $O$ incremento de outras formas de participação também.

Outro fator decisivo é a universalização da internet. As redes são ambientes de interação e não ambientes de participação, nos quais as manifestações não são planejadas e não existe um ponto central que orienta a mobilização. Assim, o ambiente virtual propicia que as pessoas sejam ouvidas sem intermediários. $\mathrm{Na}$ opinião de Augusto de Franco $^{24}$, as mídias e a internet favorecem a interatividade, e

${ }^{23}$ SZAZI, Eduardo. NGOS. Legimate Subjects of Internacional Law. Thesis PhD, International Law. Universiteit Leiden, 2013.

${ }^{24}$ TEDx Liberdade - Advancing our world through Civil Society Action - The Power of Together. São Paulo, 2014. Disponível em: <http://www.tedxliberdade.com/>. Acesso em: 15 ago.2014. 
os eventos começam a ocorrer em tempo real. A chamada fenomenologia da interação permitiu as diversas manifestações públicas de ocupação das ruas que ocorreram em diferentes partes do mundo, nos últimos anos (Tunísia, Egito, São Paulo, Madri, Venezuela, entre outras), escancarando o fato de que as regulações estatais não são suficientes para atender às demandas que surgem na sociedade.

Outra explicação, de natureza normativa, é a existência de regras mais repressivas de combate ao terrorismo após o 11 de setembro. Este tema foi objeto de estudo no Relatório "Counter-terrorism, 'policy laundering' and the FATF: legalising surveillance, regulating civil society" 25 publicado, em 2012, pelo Transnational Institute, que demonstra como a criação de um sistema internacional de controle à lavagem de dinheiro e combate ao terrorismo, o Financial Action Task Force - FATF, formado por instituições financeiras internacionais, contribuiu para o surgimento de legislações nacionais restritivas ao financiamento internacional de OSC.

Sobre a existência de uma escalada por governos autoritários contra grupos que promovem a visão ocidental de democracia liberal não apenas como eleições regulares, mas como debate pluralista público, fazemos referência a recente matéria veiculada no sítio da internet da revista The Economist, de 13 de setembro de $2014^{26}$. Segundo a revista, Egito, Hungria, Azerbaijão, México, Paquistão, Rússia, Sudão e Venezuela têm leis aprovadas, nos últimos dois anos, que impactam OSC que recebem fundos estrangeiros. E ainda cerca de uma dúzia de países estariam planejando fazê-lo, incluindo Bangladesh, Egito, Malásia e Nigéria. ONGs voltadas para a construção da democracia ou direitos humanos são as mais afetadas, porém a repressão também atinge aquelas ativas em outras áreas, como a saúde pública.

Matéria recentemente veiculada no site da Human Rights Watch, intitulada "Russia: Government against Rights Groups" 27 menciona a existência de normas

\footnotetext{
${ }^{25}$ HAYES, Ben. Counter-terrorism, 'policy laundering' and the FATF: legalising surveillance, regulating civil society. Transnational Institute / Statewatch: Hague, 2012. Disponível em: $<$ http://www.tni.org/sites/www.tni.org/files/download/fatf_report-update_0.pdf>. Acesso em: 25 ago. 2014.

26 "More and more autocrats are stifling criticism by barring non-governmental organisations from taking foreign cash" Disponível em <http://www.economist.com/news/international/21616969-moreand-more-autocrats-are-stifling-criticism-barring-non-governmental->. Acesso em: $01 \mathrm{dez} .2014$.

27 Disponível em: <http://www.hrw.org/news/2014/11/20/russia-government-against-rights-groups>. Acesso em: $01 \mathrm{dez} .2014$.
} 
que determinam o registro e a fiscalização de organizações no Ministério da Justiça de organizações que estejam envolvidas em atividades políticas e que recebam recursos internacionais.

Essas referências apontam para o fato de que nossa hipótese inicial no sentido de que existe um cenário de maior controle e interferência sobre as organizações da sociedade civil no Brasil está inserido numa tendência internacional, mais ampla, de recrudescimento na legislação dos países no que se relaciona às OSC. Apesar de interessar-nos especificamente neste estudo o caso brasileiro, é importante pontuar os trabalhos da Relatoria Especial da ONU sobre liberdade de reunião e de associação pacíficas, que nos ajudam a enxergar, de uma perspectiva global, esse cenário com mais clareza.

\subsection{RELATORIA ESPECIAL DA ONU SOBRE LIBERDADE DE REUNIÃO E DE ASSOCIAÇÃO PACÍFICA}

Sintonizado com o cenário internacional, em setembro de 2010, o Conselho de Direitos Humanos na ONU, criou uma Relatoria Especial para estudar o tema das liberdades de reunião pacífica e associação.

O primeiro relatório publicado estabelece as melhores práticas e questões para orientar os Estados na promoção e proteção das liberdades de reunião e de associações pacíficas, tanto no plano formal quanto no material.

Apresentado pelo relator especial, Sr. Maina Kiai, em 20 de junho de 2012, durante a vigésima sessão do Conselho, em Genebra, o documento traz importantes constatações sobre o direito de Liberdade de Associação:

(i) reconhece que o direito de Liberdade de Associação abrange a análise do tratamento que os países conferem às organizações da sociedade civil, mas também aos partidos políticos, sindicatos, entidades religiosas, entre outras organizações privadas e independentes do Estado;

(ii) menciona que a principal dificuldade enfrentada por estas organizações em diferentes países do mundo é o controle estatal anterior à sua criação, com a necessidade de "autorizações" públicas como condição à sua instalação e funcionamento; 
(iii) reafirma que os direitos à liberdade de reunião pacífica e de associação desempenham um papel decisivo no surgimento e existência de eficazes sistemas democráticos, uma vez que são favoráveis ao diálogo, tolerância, pluralismo e abertura de espírito, nos quais grupos minoritários e opiniões divergentes são respeitadas; e

(iv) constata também que o direito à Liberdade de Associação está ligado à capacidade das organizações acessarem fundos e recursos financeiros.

$\mathrm{Na}$ Assembleia Geral do Conselho de Direitos Humanos da ONU, de 27 de setembro de 2012, foi editada Resolução que reconheceu a importância de uma sociedade civil global livre e auto-organizada e a Liberdade de Associação como elemento para sua conformação, e que mantém a continuidade do trabalho da relatoria, reforçando sua importância. A Resolução salienta que o respeito aos direitos à liberdade de reunião pacífica e de associação contribui para enfrentar e resolver desafios e questões importantes para a sociedade, tais como o ambiente, o desenvolvimento sustentável, prevenção da criminalidade, o tráfico humano, capacitando mulheres, a justiça social, defesa do consumidor e para a realização de todos os direitos humanos.

No mês de abril de 2013, o Relator Especial apresentou ao Conselho de Direitos Humanos da ONU o segundo relatório em que trata do tema do financiamento das OSC, como meio para proporcionar seu desenvolvimento, seja de fontes nacionais ou internacionais.

Já o terceiro relatório de outubro de 2013, trata da liberdade de associação e de reunião como parte dos processos democráticos e como meio vital para indivíduos e grupos de indivíduos participarem dos assuntos públicos.

Por fim, o último relatório, de junho de 2014, aborda os desafios enfrentados por grupos sociais em maior situação de risco, ou que se encontram à margem da sociedade que tem suas situações agravadas quando o exercício dos direitos de liberdade pacífica de reunião e de associação são obstaculizados.

No tocante aos relatórios apresentados por Maina Kiai, é interessante observar que a linha temática obedeceu à lógica evolutiva que normalmente se 
verifica nos processos de afirmação de direitos humanos ${ }^{28}$ : uma fase inicial de reconhecimento formal e positivação no âmbito global, uma etapa de internalização e a subsequente ampliação dessa esfera geral de proteção para a proteção de grupos específicos.

Também é possível identificar que o direito de liberdade de associação é promotor da democracia e da redução das desigualdades.

Nessa direção, cabe aos Estados signatários dos tradados internacionais que asseguram esses direitos, tomar as medidas necessárias para que sejam repeitados e que a atuação estatal, seja pelo Executivo, Legislativo ou Judiciário, não crie obstáculos para a sua efetivação.

\subsection{INICIATIVAS DA SOCIEDADE CIVIL}

Em que pese a positivação da Liberdade de Associação e dos direitos fundamentais das OSC no plano internacional, a realidade tem mostrado a necessidade de aprofundar 0 estudo das dificuldades enfrentadas pelas organizações da sociedade civil nos países, reforçando a importância e atualidade do trabalho da Relatoria. Alguns outros trabalhos internacionais dialogam com as atividades da Relatoria Especial da ONU e se alinham a essa tendência.

A segunda edição do Relatório "Protegendo a Sociedade Civil", de coautoria entre o International Center for not-for Profit Law - INCL e o World Movement for Democracy Secretariat at the National Endowment for Democracy (NED), publicada em 2012, traz informações sobre o expressivo número de governos, não exclusivamente autoritários, que estão usando medidas legais e regulamentares para restringir a sociedade civil, medidas essas que o relatório analisa e classifica em seis categorias: (1) barreiras à entrada; (2) barreiras ao funcionamento; (3) barreiras à expressão e defesa; (4) barreiras à comunicação; (5) barreiras à criação; e (6) barreiras aos recursos.

Este estudo afirma que o impacto de medidas restritivas legais ultrapassa as organizações e indivíduos imediatamente a elas sujeitos, levando a um

\footnotetext{
${ }^{28}$ BOBBIO, Noberto. A Era dos Direitos. 8. ed. Rio de Janeiro: Campus, 1992.
} 
arrefecimento da sociedade civil de forma mais ampla e mais difícil de medir. Estabelece também uma tendência prevalente nos regimes autoritários e semiautoritários a uma regulamentação mais dura e punitiva das organizações da sociedade civil, havendo, todavia, razões para preocupação nas democracias desenvolvidas ou consolidadas, citando o caso da Argentina, por exemplo, cuja lei permite dissolução de uma OSC quando "necessário" ou "relevante interesse público", e dos Estados Unidos, onde tem sido noticiado o fechamento de instituições de caridade supostamente associadas a terroristas, bem como violação de sigilo telefônico e de correspondência de OSC.

Especificamente sobre as barreiras ao financiamento, o Relatório afirma que a lei pode ser usada para restringir a capacidade das OSC de garantirem os recursos necessários, consistindo verdadeiro entrave para o financiamento e apresentando um rol ilustrativo de normas que estabelecem essas barreiras em diversos países, autoritários e democráticos, que vão desde Venezuela, Egito, Zimbábue até Argentina e Estados Unidos.

O já mencionado Relatório "Counter-terrorism, 'policy laundering' and the FATF: legalising surveillance, regulating civil society", traz o histórico da estruturação do sistema internacional de combate à lavagem de dinheiro chamado Financial Action Task Force - FATF, a partir da ideia de coibir o financiamento do terrorismo, e o consequente endurecimento das exigências de que as organizações submetam informações e se sujeitem ao poder da polícia de governos. O estudo demonstra que, nas suas ações de monitoramento, o FATF avalia e enaltece países cuja legislação é dura com relação às OSC. Países como Arábia Saudita, Tunísia e Egito, que possuem legislação extremamente rígida e repressiva para o financiamento internacional de OSC, receberam alta pontuação segundo as avaliações realizadas.

Para buscar mudar este cenário, que é desproporcionalmente mais rígido para as OSC, foi formada uma coalizão internacional de organizações que está trabalhando no sentido de realizar ações de incidência junto ao FATF para que suas ações de monitoramento respeitem os padrões internacionais relacionados ao gozo ao direito de Liberdade de Associação.

Medidas como estas ganham papel fundamental na reversão do cenário de dificuldades que as OSC vêm enfrentando em âmbito global. Outras iniciativas 
também buscam monitorar e contribuir para a confirmação de ambientes jurídicoinstitucionais mais favoráveis para o desenvolvimento das OSC nos países.

$\mathrm{Na}$ América Latina, destaca-se a também já mencionada articulação da "Mesa de Articulação de América Latina e Caribe e seus Aliados do Sul Aumentam sua Capacidade de Incidência e Diálogo com Governos e Setor Privado", que tem o objetivo de diagnosticar a situação e promover, a partir do desenvolvimento de capacidades e políticas para a sustentabilidade, um ambiente propício à atuação das OSC da região. Esse trabalho, desenvolvido pela Mesa de Articulação da América Latina e do Caribe e seus Aliados do Sul, movimento que congrega plataformas, associações e redes nacionais de OSC de vários países latino-americanos, desenvolveu um levantamento completo de informações sobre o rol das OSC, seu financiamento e marcos jurídicos na Argentina, Brasil, Chile, Paraguai e Uruguai, Bolívia, Colômbia, Equador, Peru, Venezuela, México, Guatemala, Honduras, El Salvador e Nicarágua.

Em julho de 2012, um grupo de professores de Direito para Organizações da Sociedade reuniu-se em San Pedro Sula - Honduras, num congresso a respeito de ensino jurídico sobre organizações da sociedade civil, promovido pela Universidade de San Pedro Sula, com apoio do International Center for Non Proft Law - ICNL, na ocasião, criou-se uma Red Interamericana de Derecho delas Organizaciones da Sociedade Civil, que reúne profissionais e estudiosos do tema.

Verifica-se a preocupação originária de diferentes setores da sociedade, em âmbito global, de que a regulamentação dos países sobre as Organizações da Sociedade Civil não se constitua numa barreira ao desenvolvimento dessas iniciativas da sociedade. $O$ tema ganha tanto destaque pois existe o reconhecimento comum de que a existência de OSC livres, plurais e independentes tem correlação direta com a garantia e a preservação da democracia, num mundo cujos desafios a serem enfrentados depende de uma melhor interação entre governo e diferentes segmentos da sociedade.

De acordo com a análise do professor Fernando Dias Menezes de Almeida ${ }^{29}$, a liberdade de associação (assim como a liberdade de reunião) foi reconhecida tardiamente e assume crescente importância nos dias atuais. $O$ reconhecimento 
tardio dessas liberdades seria explicado pela ausência do valor da ação coletiva na ideologia liberal e pelo temor dos governos com relação à ação fortalecida de grupos. Já a importância nos dias de hoje seria decorrente da conformação atual das sociedades, marcadamente urbanizadas e complexas, nas quais haveria maior necessidade de espaços coletivos para as ações políticas, profissionais e de difusão de informações, seja por meio das associações sindicais, profissionais, organizações da sociedade, reuniões e manifestações.

Nesse sentido, ações de instituições internacionais voltadas à proteção dos diretos humanos têm atuado para que a regulamentação dos países sobre as organizações da sociedade civil não constitua barreira ao desenvolvimento desse segmento. 


\section{AS TRÊS DIMENSÕES DA LIBERDADE DE ASSOCIAÇÃO: NÃO INTERFERÊNCIA, PARTICIPAÇÃO E FINANCIAMENTO}

O direito de liberdade de associação tem especificidades quando se trata de organizações da sociedade civil. Os Estados comprometidos com a democracia e com os direitos humanos internacionais devem criar condições para que as OSC deliberem de forma autônoma sobre as questões que Ihes são próprias, sem interferir em seu funcionamento. Integra esse dever estatal criar condições para que essas organizações atuem livremente, realizem ações de controle social e se manifestem. A esses deveres soma-se a necessidade de que o Estado crie políticas para se relacionar com essas organizações, por meio do estabelecimento de instâncias voltadas à sua participação, mas também com o incentivo à difusão de boas iniciativas da sociedade que possam contribuir para o seu desenvolvimento.

Com base na análise das diferentes dimensões abarcadas pelo direito de liberdade de associação e a sua aplicação às organizações da sociedade civil, identificamos que este envolve o respeito a três dimensões de direitos: não interferência estatal; participação; e financiamento.

\subsection{NÃO INTERFERÊNCIA}

A dimensão da não interferência estatal tem como principal bem jurídico tutelado o direito subjetivo das organizações e dos indivíduos que as integram se auto-organizar sem a interferência indevida do Estado. Trata-se de garantia para que cada cidadão desenvolva e participe livremente de atividades lícitas, autoadministradas e voltadas à finalidade que bem lhes entender.

O exercício dessas liberdades pode ser fundamental também para a ação pública e para garantir o livre exercício de direitos civis e políticos.

Não interferir no funcionamento das OSC significa estabelecer um ambiente jurídico que favoreça a criação, regular funcionamento e a auto-organização das OSC. Nessa dimensão, a liberdade de associação é equiparável à liberdade de pensamento, de expressão e de informação e envolve, num primeiro plano, a ausência de barreiras estatais para a livre criação e funcionamento dessas 
entidades, como também ação protetiva do Estado no sentido de evitar a criação de normas que impactem desnecessariamente a gestão interna das OSC.

Boa parte dos problemas relatados com relação às OSC é em relação à excessiva burocracia, dificuldades para obtenção de direitos e insegurança jurídica com relação às normas aplicáveis, que dificultam 0 desenvolvimento das organizações e, não raramente, inviabilizam a sua existência.

Esta profusão de normas que invade o plano mais individual da liberdade de associações impacta negativamente na sua dimensão mais voltada à ação coletiva. Assim, as normas jurídicas e práticas administrativas devem zelar por manter a independência dessas organizações, que são livres para propor e desenvolver novos modelos socioprodutivos, praticar atos de comércio, criar suas próprias regras para admissão e exclusão de associados, estabelecer as suas políticas de recursos humanos e contratação com fornecedores, tudo a depender de uma série de variáveis típica de cada organização.

Estabelecer critérios para o funcionamento interno das OSC pode significar retirar-Ihes a essência, a inovação nas suas ações, o que poderá resultar em instituições com menor capacidade de se desenvolver adequadamente, e de (caso decidirem fazê-lo), realizar atividades ligadas às outras duas dimensões do direito de liberdade de associação das OSC: a participação e o financiamento.

\subsection{PARTICIPAÇÃO}

A dimensão da participação das OSC surge quando a organização passa a desenvolver atividades mais ligadas ao exercício do direito de liberdade de associação como uma liberdade pública voltada à ação coletiva. Nesta dimensão, encontram-se os direitos de representação coletiva dos associados pelas organizações que os representam, inclusive para fins de representação judicial coletiva.

Reconhecer a dimensão da participação como parte do direito de liberdade de associação envolve o direito das pessoas se organizarem juridicamente para, legitimamente, buscar influenciar ações públicas, seja de forma autônoma ou livremente associando-se. 
A ideia de participação encontra fundamentos não apenas num contexto político e social, mas também do ponto de vista da economia voltada à superação das desigualdades.

Em sua obra "Desenvolvimento como Liberdade", Amartya $\operatorname{Sen}^{30}$ afirma que a democracia seria capaz de conformar uma espécie de "segurança protetora", preventiva de desastres em geral, sendo os direitos econômicos sociais conformados pela oferta da chamada rede de proteção social e os direitos e liberdades políticas, pela oportunidade de participação pelos direitos e liberdades civis, "cruciais até mesmo para os direitos econômicos e para a sobrevivência". A abordagem de Amartya Sen identifica com clareza a importância atribui à participação da sociedade civil na vida pública como elemento essencial para a democracia. Sen ainda nos alerta para a importância de se apoiar a manutenção das instituições das quais a democracia depende, já que é comum que as pessoas vulneráveis não sintam falta da democracia quando a economia vai bem, porém, no caso da instauração de uma crise, a ausência de democracia prejudica ainda mais os já vulneráveis, que têm suas vozes abafadas, justamente quando estes canais Ihes seriam tão necessários.

As organizações da sociedade civil são instituições mediadoras entre os diferentes segmentos da sociedade e podem constituir verdadeiras pontes no sentido de diminuir do distanciamento entre governantes e governados e maior circulação da informação de relevância pública, impulsionando o avanço e a consolidação das democracias nas sociedades, com potencial de redução da assimetria de informação, que é uma das principais razões de perpetuação da desigualdade, a sustentar a existência de mercados irreais, segundo o Prêmio Nobel da Economia, Akerlof ${ }^{31}$. Este seria, portanto, mais um dos relevantes aspectos que fundamentam a participação com um direito intimamente relacionado às sociedades democráticas. A ação coletiva por meio de organizações da sociedade civil é capaz de corrigir, ao menos em parte, a assimetria de informação entre o cidadão e o Estado, contribuindo para a redução de desigualdades e podendo representar avanço na gestão de bens e de interesses comuns.

\footnotetext{
${ }^{30}$ SEN, Amartya. Desenvolvimento como liberdade. São Paulo: Companhia das Letras, 2000.

31 AKERLOF, George. The Market for Lemons: Quality Uncertainty and the Market Mechanism. Quarterly Journal of Economics, v. 84, n. 3, p. 488-500, ago. 1970.
} 
A criação de espaços para participação por meio da representação de interesses através de organizações da sociedade civil tem sido mecanismo de grande importância para o controle social das políticas de gestão pública, que visam a democratizar o conhecimento sobre políticas públicas e difundir informações de interesse geral.

Organizar-se livremente para a prática da cidadania passa pelo reconhecimento da ideia de que há coisas que muito embora os indivíduos possam, de modo geral, não fazer tão bem quanto o Estado, ainda assim é interessante que o façam, dado que fazê-lo contribui para a prática da cidadania e é uma forma de as pessoas se habituarem a decisão coletiva e com decisões que alcancem o interesse público ${ }^{32}$.

Quando se institucionaliza a participação por meio de reserva de assentos em órgãos consultivos ou deliberativos, como é o caso dos Conselhos de Políticas Públicas e de outros mecanismos formais previstos na legislação, surge a necessidade de que o Estado crie condições para que esta participação tenha qualidade suficiente para conseguir se efetivar no plano material.

Nesse contexto, propostas voltadas a evitar a cooptação das OSC pelo próprio Estado ou por outros interesses não revelados deve ser uma preocupação permanente. Outro aspecto é a busca por transparência e permeabilidade, com troca de informações e a construção conjunta de conhecimento sobre participação em cada área de interesse, envolvendo atores de diferentes segmentos da sociedade.

$\mathrm{Na}$ crítica de Patricia Lucki $^{33}$, o principal problema ocorre quando os mecanismos de participação não decorrem da proposta espontânea dos cidadãos, mas quando são organizados pelos governos, situação em que as OSC tendem a ocupar espaços mais voltados a compreender como funcionam as políticas e legitimar as decisões dos governos, como "objeto" da participação, ao invés de assumir papel mais protagonista, como "sujeito" da participação.

A crítica não diminui a importância da participação dos cidadãos nos espaços previstos e formatados pelos Estados no ciclo das políticas púbicas, mas apenas

\footnotetext{
${ }^{32}$ MILL, John Stuart. Sobre a Liberdade. Trad. Pedro Madeira. Rio de Janeiro: Nova Fronteira, 2011. ${ }^{33}$ Op. cit.
} 
reconhece a limitação deste tipo de mecanismo no sentido de promover mudanças mais profundas.

$\mathrm{Na}$ dimensão de participação estão inseridos outros temas não relacionados à representatividade institucionalizada em espaços formais, mas à existência (e resistência) de organizações com forte papel comunitário, capazes de exercer ações de preservação de interesses de grupos específicos, alguns dos quais são objeto de proteção especial. É o caso de organizações locais de desenvolvimento, entidades ligadas a comunidades tradicionais, OSC formadas por pessoas e grupos especialmente ameaçadas, como mecanismos políticos de participação autônoma e independente da sociedade, na configuração de formas alternativas de disputa política e de arranjos sociais e econômicos.

Em sua consagrada obra "Governing the Commons" 34 , a estudiosa Elinor Ostrom analisou diferentes estudos de caso sobre a gestão de bens comuns e determinou que bens comuns são mais bem-geridos pela comunidade do que isoladamente pelo Estado. Sua pesquisa demonstra que a gestão de bens comuns tendentes à escassez costuma ser mais eficiente quando feita por um grupo formado por pessoas diretamente impactadas pela gestão daquele bem, a partir de regras criadas pelo próprio grupo, bem adaptadas às necessidades e condições locais, respeitadas por terceiros, inclusive autoridades externas. Neste tipo de arranjo que foi objeto de estudo de Ostrom, destaca-se a existência de sistemas de monitoramento dos membros do grupo, feito pelo próprio grupo, que dispõe de mecanismos de resolução de conflitos de baixo custo através de um sistema hierarquizado de sanções. As organizações responsáveis pela gestão desses bens são tipicamente organizações da sociedade civil, com um caráter mais comunitário e ligado à promoção do desenvolvimento econômico e social, com preservação do meio ambiente, por meio da gestão de um bem comum.

Neste e em outros casos em que a atuação das organizações da sociedade civil atende aos interesses da coletividade é que se consubstancia o direito (e o dever) do Estado e da sociedade em financiar estas ações. Nestes casos é que se

${ }^{34}$ OSTROM, Elinor. Governing the Commons: The Evolution of Institutions for Collective Action. Cambridge: Cambridge University Press, 1990, p. 1-28;103-142. 
coloca a discussão do financiamento como a terceira dimensão do direito de liberdade de associação para as OSC.

\subsection{FINANCIAMENTO}

Na dimensão de financiamento o Estado pode atuar direta ou indiretamente.

Ao atuar diretamente, o Estado normalmente o faz por meio do que chamamos de relações de contratualização, ou seja, celebrando com as organizações instrumentos revestidos da forma contratual para desempenho de atividades de interesse mútuo. Esta dimensão está diretamente relacionada à liberdade de associação da OSC como uma Liberdade Pública voltada à Cooperação com o Estado.

De forma indireta, o Estado pode criar mecanismos para de incentivos fiscais a doações, de desoneração e simplificação fiscal para as OSC ou para aqueles que doam a essas instituições essenciais para o fortalecimento da democracia e redução das desigualdades.

A administração de recursos públicos por OSC evidentemente envolve a aceitação por essas entidades em seguir normas relacionadas à aplicação de recursos públicos. Todavia, em respeito às demais dimensões da liberdade de associação a aplicação dessas normas deve se dar na menor medida para a proteção do interesse público envolvido em cada relação.

O acesso ao financiamento público deve ser normatizado de forma clara para evitar relações de cooptação, apadrinhamento ou excessiva discricionariedade na concessão de recursos destinados à promoção do desenvolvimento social. Chamamentos Públicos simplificados, abertos a diversas organizações, devem ser estimulados, como também mecanismos eficientes de controle social sobre as ações realizadas pelas OSC com recursos públicos.

A atuação colaborativa fortalece a democracia e aproxima os cidadãos das políticas públicas, servindo, portanto, ao interesse do próprio Estado e da coletividade, e não das instituições como um fim em si mesmas.

A cooperação do Estado com OSC deve ser objeto de uma atuação efetiva a partir da dimensão de funcionamento da liberdade de associação. 
Reconhecer essas três dimensões integrantes da liberdade de associação envolve assegurar que esta seja colocada em prática através do estímulo ao direito ao desenvolvimento ${ }^{35}$, da educação para a cidadania e do respeito ao valor existente na diversidade e na experimentação livre de iniciativas pelos indivíduos. O Estado que capta apropriadamente as inovações sociais tem ótima oportunidade de propor e programar políticas públicas mais adequadas às pessoas e localidades, atuando como depositário e difusor das boas iniciativas da sociedade.

Podemos, assim, afirmar que o Estado que se relaciona com a OSC de forma a respeitar a liberdade de associação, garantindo sua liberdade de existir, agir e manifestar-se, cria espaços públicos ou semipúblicos para a prática da cidadania e apoia e multiplica as boas iniciativas que contribuam para o desenvolvimento da sociedade.

35 ONU. Declaração de Direito ao Desenvolvimento. 1961, art. 1ำ conceitua o direito ao desenvolvimento como "[...] um direito humano inalienável, em virtude do qual todo ser humano e todos os povos têm direito de participar, contribuir e gozar do desenvolvimento econômico, social, cultural e político no qual todos os direitos humanos e liberdades fundamentais podem ser plenamente realizados". 


\section{ELEMENTOS CARACTERIZADORES DAS ORGANIZAÇÕES DA SOCIEDADE CIVIL}

As organizações da sociedade civil costumam ser identificadas como aquelas que integram o chamado terceiro setor. Terceiro Setor é uma expressão que define um setor da economia a partir do resultado da interação de agentes em razão dos interesses que perseguem, normalmente, caracterizado na doutrina como a atuação de agentes privados (particulares), para alcance de finalidade pública (coletiva).

Para definir Terceiro Setor é necessário estabelecer sua distinção em relação aos dois outros setores da economia, a saber, o Estado (Primeiro Setor ou Setor Público) e o Mercado (Segundo Setor ou Setor Privado), tendo por base a interação que existe entre os agentes envolvidos em cada um dos setores e os interesses que perseguem, respectivamente.

O Estado, ou Primeiro Setor, é integrado por agentes públicos que atuam em prol do interesse público ou coletivo, ou seja, canaliza suas ações para satisfazer os interesses da coletividade.

O Segundo Setor é o Mercado, assim entendido o setor composto por agentes privados que agem com vistas à satisfação de interesses privados ou particulares.

O Terceiro Setor, por sua vez, congrega iniciativas de natureza privada, independentemente de qualquer colaboração do Estado, com vistas à realização de interesses coletivos ou do interesse público, funcionando ainda como instância de pressão pública e de controle social sobre as atividades governamentais. São as chamadas Organizações da Sociedade Civil.

Há quem fale no "Quarto Setor" da economia, o setor invisível, que não aparece nas contabilidades dos governos, empresas e instituições, que também movimenta uma parcela significativa de recursos, que seria a parte da economia movimentada pela corrupção. 
Para o sociólogo Rubem César Fernandes ${ }^{36}$, o conceito de Terceiro Setor é uma das combinações resultantes da conjunção entre o universo público e privado: "Ou seja, o conceito denota um conjunto de organizações e iniciativas privadas que visam à produção de bens e serviços públicos [...] não geram lucros e respondem a necessidades coletivas".

Terceiro Setor este que, na opinião de Eduardo Sabo Paes, é "o conjunto de organismos, organizações e instituições sem fins lucrativos dotados de autonomia e administração própria que apresentam como função e objetivo principal atuar voluntariamente junto à sociedade civil visando ao seu aperfeiçoamento" ${ }^{\text {"37 }}$.

Neste ponto é importante frisar o caráter privado das entidades do Terceiro Setor e que a sua atuação possa ser independente de qualquer colaboração do Estado, como entidades típicas de uma sociedade civil e organizada que atua de forma crítica e independente, fazendo pressão pública e exercendo o controle social sobre as atividades governamentais.

Hoje em dia, tem-se preferido utilizar a terminologia "organizações da sociedade civil", na medida em que a expressão "Terceiro Setor" (embora já um tanto consolidada na área do Direito e da Administração), estaria excessivamente associada ao processo da reforma do Estado, passando a percepção de que essas entidades necessariamente atuam como "braços do Estado", ou que tenham sido criadas para o fim exclusivo de servir como instrumento de transferência, delegação, ou "terceirização" de atividades da Administração Pública.

Acredita-se que expressão "Terceiro Setor" pode ser entendida como um segmento da economia ao qual caberia uma espécie de competência residual, cabendo-Ihe atuar nas questões sociais e de políticas públicas em que as empresas e o Estado não o fazem (ou não se interessem em fazê-lo) de forma satisfatória, quando, na verdade, esse seria o setor em que a sociedade cuidaria do interesse público de forma independente do Estado.

\footnotetext{
${ }^{36}$ FERNANDES, Rubem César. Privado, porém público: o terceiro setor na América Latina. 3. ed. Rio de Janeiro, CIVICUS, 2002, p. 33.

${ }_{37}$ Paes, José Eduardo Sabo. Fundações, Associações e Entidades de Interesse Social:Aspectos jurídicos, administrativos, contábeis, trabalhistas e tributários. 6. ed. Brasília: Brasília Jurídica, 2006, p. 87.
} 
O termo "organizações da sociedade civil" tem sido utilizado por movimentos sociais, articulações da sociedade civil e pelo próprio Estado em substituição a "organizações do Terceiro Setor".

Foi adotada por um conjunto de entidades e movimentos bastante representativos do segmento, em uma articulação criada no ano de 2010, em torno de um novo marco regulatório para essas entidades: a Plataforma por um Novo Marco Regulatório para as Organizações da Sociedade Civil.

A recente Lei Geral das Parcerias das OSC, Lei 꾸13.019/2014, também utiliza a expressão "Organização da Sociedade Civil" para designar esse universo de organizações, assim conceituadas nos termos do inciso I do seu art. 2 :

\begin{abstract}
Pessoa jurídica de direito privado sem fins lucrativos que não distribui, entre os seus sócios ou associados, conselheiros, diretores, empregados ou doadores, eventuais resultados, sobras, excedentes operacionais, brutos ou líquidos, dividendos, bonificações, participações ou parcelas do seu patrimônio, auferidos mediante o exercício de suas atividades, e que os aplica integralmente na consecução do respectivo objeto social, de forma imediata ou por meio da constituição de fundo patrimonial ou fundo de reserva.
\end{abstract}

Conquanto não seja nossa pretensão, neste trabalho, fixar um entendimento sobre a expressão mais adequada para se referir a essas entidades, optamos por utilizar a designação de "organizações da sociedade civil".

Assim optamos em razão de sua abrangência, capaz de abarcar toda a diversidade e heterogeneidade do segmento, inclusive aquelas entidades que não estabelecem, nem pretendem estabelecer, qualquer tipo de relação ou atuação conjunta com o Estado.

Para delimitar o universo das organizações da sociedade civil, valemo-nos da pesquisa nacional denominada Fundações Privadas e Associações sem Fins Lucrativos - FASFIL - realizada nos anos de 2002 e 2005, em parceria com IBGE, IPEA, ABONG e GIFE, cuja terceira edição foi editada em $2012^{38}$, e utiliza os seguintes critérios propostos pela Classification of the Purpose of Non-Profit

38 IBGE (Instituto Brasileiro de Geografia e Estatística); IPEA (Instituto de Pesquisa Econômica Aplicada). As Fundações Privadas e Associações Sem Fins Lucrativos no Brasil 2010. Rio de Janeiro: IBGE/IPEA, 2012. 
Institutions Serving Householdes - COPNI -, da ONU: privadas; sem fins lucrativos; institucionalizadas; autoadministradas; e voluntárias.

\section{$5.1 \quad$ PRIVADAS}

As organizações da sociedade civil têm natureza privada, ou seja, não podem ser integrantes do aparelho estatal, pois se originam de forma espontânea e desvinculada do Estado para conduzir determinado conjunto de atividades visando ao alcance de um fim específico.

O caráter essencialmente privado dessas entidades tem como premissa o fato de serem elas voluntárias e autoadministradas, fatores determinantes para manutenção de sua autonomia e independência. Todavia nem sempre esses limites são precisos e bem identificados, havendo entidades que são consideradas, para alguns efeitos, organizações da sociedade civil, mesmo tendo sido criadas por lei ou sendo controladas pelo Poder Público.

Exemplos desses casos são instituições públicas que, por ocasião da edição da Lei das Organizações Sociais - OS, foram extintas e qualificadas como "OS" nos termos da redação do caput do art. 21 e de $3^{\circ}$ da Lei ํo9.637/98. ${ }^{39}$

Os serviços sociais autônomos, as entidades do chamado "Sistema S", também se encontram em situação peculiar, pois, apesar de sua natureza jurídica de direito privado, foram criadas por lei e são financiadas por contribuições impostas de forma obrigatória às empresas, cuja arrecadação ocorre por intermédio do aparelho estatal, numa espécie sui generis de contribuição obrigatória, de natureza não tributária, que se convencionou chamar de "contribuição paraestatal".

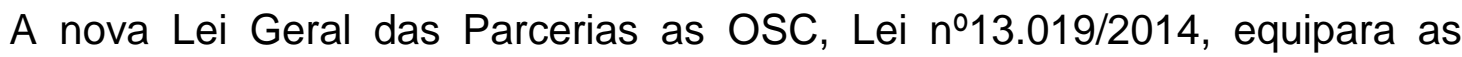
entidades do "Sistema S" a OSC para fins de celebração dos Termos de Fomento e dos Termos de Colaboração, conforme a redação do parágrafo único do art. 33 e

\footnotetext{
${ }^{39}$ Art. 21. São extintos o Laboratório Nacional de Luz Síncrotron, integrante da estrutura do Conselho Nacional de Desenvolvimento Científico e Tecnológico - CNPq, e a Fundação Roquette Pinto, entidade vinculada à Presidência da República. [...]

$\S 3^{\circ}$ É o Poder Executivo autorizado a qualificar como organizações sociais, nos termos desta Lei, as pessoas jurídicas de direito privado indicadas no Anexo I, bem assim a permitir a absorção de atividades desempenhadas pelas entidades extintas por este artigo.
} 
$\S 3^{\circ}$ do art. 39. Em que pese ser justificável que entidades do Sistema $S$ recebam financiamento estatal, parece-nos que a sua equiparação a organizações da sociedade civil para fins de aplicação da Lei 13.019/2014 pode gerar dificuldades de interpretação da lei em dispositivos específicos, e distorções práticas na aplicação da Lei, que não foi pensada para organizações com as características dos serviços sociais autônomos.

\subsection{SEM FINS LUCRATIVOS}

Outro elemento que caracteriza as organizações da sociedade civil é a sua finalidade não lucrativa. O principal aspecto que determinará a finalidade não lucrativa de uma pessoa jurídica é a obrigatoriedade de destinar seu eventual lucro ou superávit para a sua finalidade social. Assim, uma associação pode ter superávit, mas deverá invariavelmente reaplicá-lo no desenvolvimento de seus objetivos institucionais, ao contrário das empresas cuja finalidade lucrativa autoriza a distribuição dos lucros aos sócios.

O Código Tributário Nacional (CTN) - Lei ํ⒌172, de 15 de outubro de 1966, ao estabelecer os requisitos necessários para o gozo de imunidades por instituições de educação e de assistência social, sem fins lucrativos, assim, dispõe:

\footnotetext{
Art. 14. O disposto na alínea $c$ do inciso IV do artigo $9^{\circ}$ é subordinado à observância dos seguintes requisitos pelas entidades nele referidas:

I - não distribuírem qualquer parcela de seu patrimônio ou de suas rendas, a qualquer título; (Redação dada pela Lcp no104, de 10.1.2001)

II - aplicarem integralmente, no País, os seus recursos na manutenção dos seus objetivos institucionais;

III - manterem escrituração de suas receitas e despesas em livros revestidos de formalidades capazes de assegurar sua exatidão.

$\S 1^{\circ}[\ldots]$.

$\S 2^{\circ}$ Os serviços a que se refere à alínea $c$ do inciso IV do artigo 9o são exclusivamente, os diretamente relacionados com os objetivos institucionais das entidades de que trata este artigo, previstos nos respectivos estatutos ou atos constitutivos.
}

Além disso, o $§ 3^{\circ}$ do art. 12 da Lei 9.532, de 10 de dezembro de 1997 (Lei do Imposto de Renda), conceitua entidade sem fins lucrativos nos seguintes termos: 
$\$ 3^{\circ}$ - Considera-se entidade sem fins lucrativos a que não apresente superávit em suas contas ou, caso o apresente em determinado exercício, destine referido resultado, integralmente, à manutenção e ao desenvolvimento dos seus objetivos sociais.

Basta, portanto, que a entidade sem fins lucrativos desenvolva suas atividades em conformidade com os seus objetivos estatutários, aplicando seus recursos para este fim. Eventual superávit deverá ser destinado a essas mesmas atividades.

A obrigação de prestação de contas é, nesse sentido, indissociável do caráter "sem fins lucrativos" porque o dever de comprovar a aplicação dos recursos no desenvolvimento de seus objetivos é inerente a este conceito.

O conceito em si é simples. Todavia, na prática, muitos desafios se apresentam ao aplicá-lo.

O Código Civil, ao conceituar as associações, define, no caput do art. 53, como "união de pessoas que se organizem para fins não econômicos".

Finalidade não econômica significa a proibição de que a razão primordial para a criação de uma associação seja o mero exercício de atividades econômicas (este restrito às "sociedades", pelo teor do art. 44 do Código Civil).

Neste contexto, a vedação à finalidade econômica das associações as impede tão somente de que a atuação no mercado seja um fim em si mesmo, ou seja, às associações não seria permitido constituir-se pura e simplesmente para "prestar serviços" ou "vender produtos", mas para "promover a experimentação de novos modelos de produção, por meio da venda de produtos e prestação de serviços." ${ }^{40}$

A discussão deste tema relaciona-se com o direito fundamental da livre iniciativa e também com a configuração de novas formas societárias. A proposta e criação de novos modelos socioprodutivos e autoadministrados (como é o caso das cooperativas, incubadoras, alguns negócios sociais, entre outros), voltados para a intervenção no modelo econômico de produção, é papel das OSC, reconhecido

${ }^{40}$ Lei 9.790/99, art. 3o, IX e seus parágrafo único. 
inclusive como iniciativa típica de organizações da sociedade civil de interesse público. $^{41}$

As organizações que se propõem a enfrentar estes desafios, criando formas alternativas de produção econômica em contraponto ao sistema vigente, para além das dificuldades de buscar financiamento, criar mercados, lidar com os interesses pessoas e comunitários dos públicos envolvidos, ainda têm de lidar com a equivocada interpretação que terceiros em geral, inclusive autoridades públicas, farão da sua aderência à sua finalidade não lucrativa.

A avaliação das atividades das organizações da sociedade civil, diante do texto do Código Civil, deve considerar o fato de que são organizações privadas (portanto, livres para fazer tudo que a lei não veda), cuja finalidade não econômica não implica qualquer proibição de realizar atividades econômicas que thes gerem receitas ou que possibilitem a consecução de seus objetivos ligados à busca por novos modelos de produção econômica e de distribuição de renda.

Neste particular aspecto é de ressaltar-se a questão da remuneração de dirigentes, que, na equivocada opinião de alguns, caracterizaria uma forma de distribuição "disfarçada" de lucros.

Em que pese a existência de normas esparsas que condicionam a

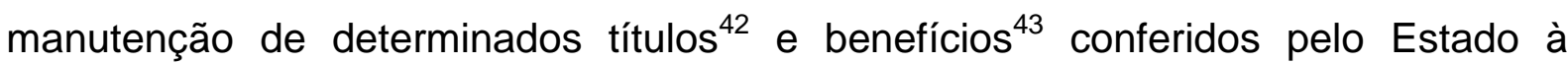
comprovação de que a entidade não remunere dirigentes, é fato que a remuneração de dirigentes, por si, não é elemento capaz de afastar o caráter sem fins lucrativos de determinada entidade. ${ }^{44}$

No Capítulo 8 deste trabalho voltaremos ao tema, ao tratar dos desafios enfrentados pelas OSC no atual contexto brasileiro.

\footnotetext{
${ }^{41}$ Lei 9790/99, art. 3ํ, IX - experimentação, não lucrativa, de novos modelos socioprodutivos e de sistemas alternativos de produção, comércio, emprego e crédito; [...].

${ }_{42}$ Lei n. 91/35, que cria o titulo de Utilidade Pública Federal.

${ }^{43}$ Art. 12 da Lei 9.532/97, com redação recentemente alterada sobre este tema pela Lei 12.868/2013.

${ }^{44} \mathrm{O}$ tema da remuneração de dirigentes será tratado de forma mais detalhada a partir da perspectiva dos direitos de personalidade das OSC no item 8.1.1.
} 


\subsection{INSTITUCIONALIZADAS}

Organização institucionalizada significa legalmente constituída e, em geral, ter seus atos constitutivos registrados nos Cartórios de Registro Civil de Pessoas Jurídicas. É a partir desse registro que a organização passa a existir juridicamente, tornando-se titular de direitos e de obrigações perante outras organizações e demais terceiros.

Da mesma forma que o nascimento de pessoas físicas é registrado no Cartório de Pessoas Naturais e, posteriormente, fazem sua inscrição no Cadastro de Pessoas Físicas do Ministério da Fazenda (CPF/MF), também as OSC costumam efetuar, cumprido o primeiro passo do registro civil de pessoa jurídica em Cartório, o seu registro junto ao Cadastro Nacional das Pessoas Jurídicas do Ministério da Fazenda (CNPJ/MF) e demais registros ligados às atividades que desenvolver.

\subsection{AUTOADMINISTRADAS}

Autonomia, autoadministração, autogoverno, independência, não interferência e liberdade de auto-organizar-se são todas expressões que traduzem a primeira dimensão de liberdade de associação ligada à não interferência.

Reconhecer a característica da autoadministração significa garantir a liberdade da organização fazer as suas escolhas de acordo com a sua convicção, os seus próprios critérios e métodos.

Essa liberdade passa por todas as facetas da organização, desde a escolha do objetivo social, do método de trabalho, escolha dos associados, financiadores, forma de administração e estrutura de governança a ser adotada.

\subsection{VOLUNTÁRIAS}

O caráter voluntário das organizações reflete, na prática, o exercício da liberdade de associação pelas pessoas que criaram a organização, reconhecida pela Constituição de 1988, em seu art. 5, XVII e seguintes, que estabelece a garantia de 
que ninguém será obrigado a associar-se ou a permanecer associado. O elemento da autonomia da vontade é diretamente ligado ao caráter privado da instituição.

Criadas a partir da manifestação da vontade de um grupo de pessoas, as organizações da sociedade civil são consideradas entidades voluntárias, cujo surgimento decorre ou se condiciona a qualquer autorização do Poder Público ou de outros órgãos de controle.

Como se pode observar, esses cinco elementos que caracterizam as organizações da sociedade civil estão diretamente ligados ao direito fundamental de liberdade de associação e são essenciais para a posterior determinação das normas incidentes sobre as instituições e quanto aos contratos públicos e privados que voluntariamente firmam.

Antes de adentrarmos mais especificamente o tema dos desafios das OSC no Brasil, é importante delimitarmos o panorama geral da legislação incidente sobre as OSC, com os principais destaques da legislação nacional. 


\section{LEGISLAÇÃO GERAL DAS ORGANIZAÇÕES DA SOCIEDADE CIVIL}

Em consonância com o fim a que se propõe este trabalho, aprofundaremos o estudo das organizações da sociedade civil sob as perspectivas que mais nos interessam, que são relativas à formatação jurídica e ao financiamento das organizações da sociedade civil ${ }^{45}$.

\subsection{FORMATAÇÃO JURÍDICA DAS ORGANIZAÇÕES}

A legislação brasileira não traz critérios rígidos para a classificação das organizações da sociedade civil, que, de acordo com o Código Civil, apenas podem ser juridicamente constituídas de duas formas: como associação ${ }^{46}$ ou fundação ${ }^{47}$.

$\mathrm{O}$ art. 44 do Código Civil brasileiro estabelece que são pessoas jurídicas de direito privado, além das empresas com fins lucrativos e dos partidos, as associações, as fundações e as organizações religiosas. Dessa maneira, a OSC que não seja uma organização de finalidade religiosa, apenas, pode se registrar em conformidade com a lei brasileira como associação ou como fundação, ambas reguladas pelo Código Civil.

As fundações caracterizam-se pela necessidade de que exista um fundo, patrimônio destinado para uma finalidade de interesse público. No ato da criação da fundação, o seu instituidor (aquele que destina seu patrimônio para a causa que constituirá a finalidade da fundação) deverá registrar sua vontade por escrito, seja por meio de uma escritura pública registrada em cartório, seja por meio de um testamento. Para constituição de uma fundação, o instituidor deve demonstrar a existência de ativos suficientes para atingir os seus fins e determinar a forma de

\footnotetext{
${ }^{45}$ STORTO, Paula. Marcos Jurídicos das Organizações da Sociedade Civil no Brasil. Associação Brasileira de Organizações Não Governamentais. Documento elaborado para o Proyecto Regional Mesa de Articulación de America Latina y Caribe y sus Aliados del Sur. São Paulo, 2013.

${ }^{46}$ Art. 53. Constituem-se as associações pela união de pessoas que se organizem para fins não econômicos.

${ }^{47}$ Art. 62. Para criar uma fundação, o seu instituidor fará, por escritura pública ou testamento, dotação especial de bens livres, especificando o fim a que se destina, e declarando, se quiser, a maneira de administrá-la.
} 
administrá-la, submetendo sua vontade à aprovação do Ministério Público, órgão responsável por zelar para que a vontade do instituidor seja mantida e por fiscalizar a correta aplicação dos recursos. Uma vez registrada, qualquer fundação terá sua administração ordinária feita por seu corpo dirigente, sob a forma do Estatuto e a supervisão do Ministério Público, que conta com Coordenadorias próprias e normas que regulamentam essa atividade em cada Estado e no Distrito Federal.

A formação das associações caracteriza-se pela união de pessoas para uma finalidade lícita de interesse comum, seja pública ou privada. Apesar de o Código Civil não fazer distinção entre os dois tipos de associação, neste trabalho são consideradas apenas as OSC que atuam na perspectiva do interesse público.

Não obstante a Constituição Federal prever a liberdade de auto-organização das associações, o Código Civil estabelece algumas regras mínimas para essas entidades, como a necessidade de que exista uma Assembleia Geral a quem cabe exclusivamente deliberar sobre a alteração do Estatuto Social e a destituição de dirigentes, sempre, mediante justa causa. O Estatuto deverá dispor, ainda, sobre o processo de aprovação das contas da organização, direitos e deveres de associados, dirigentes e estruturação das instâncias deliberativas da entidade, dessa forma, delimitando o poder e a liberdade das OSC constituídas na medida em que o seu registro não depende de qualquer autorização e o cartório que o realiza apenas verifica procedimentos formais, não tendo a prerrogativa de interferir no mérito dos dispositivos do estatuto da instituição.

$\mathrm{Na}$ atual redação do Código Civil brasileiro ${ }^{48}$, as entidades sem fins econômicos mereceram tratamento diferente do que até então vigorava. Assim é que as antigas sociedades civis sem fins lucrativos deixaram de existir, restando, com a denominação de sociedades, as entidades congregadoras de pessoas com fins lucrativos ${ }^{49}$. As aglomerações de pessoas para fins não econômicos são, a partir de então, denominadas exclusivamente de associações.

As associações e fundações também podem ser criadas por pessoas jurídicas, não havendo qualquer óbice legal à sua formalização em rede, seja na forma de Confederações, Federações, Redes, Movimentos, etc. Igualmente, nesse

\footnotetext{
${ }^{48}$ Lei n. 10.406, de 10 de janeiro de 2002, que entrou em vigor em 10 de janeiro de 2003

${ }^{49}$ Parágrafo único do art. 44 do Código Civil.
} 
aspecto, a lei não interfere no sentido de estabelecer forma ou procedimento para esse tipo de organização, tampouco estabelece os propósitos ou representações específicas para as OSC que assim se denominem.

Para registro da criação de uma associação ou fundação, devem obrigatoriamente constar do estatuto alguns preceitos de ordem pública, previstos no Código Civil $^{50}$ e na Lei de Registros Públicos ${ }^{51}$.

Especificamente com relação às Fundações, para sua constituição válida, são necessários os seguintes requisitos: (i) um patrimônio composto de bens livres e desembaraçados no momento da constituição; (ii) declaração solene da vontade do instituidor, manifestando o desejo de criar a nova pessoa jurídica com a dotação a ela destinada, por meio de Escritura Pública ou Testamento; (iii) a declaração do fim especial a que se destina a fundação; (iv) estatuto a regulamentar as atividades e a forma de administração da entidade (ou decreto, quando instituída por lei), o qual deverá sempre atender às bases deixadas pelo instituidor; (v) uma administração; (vi) o registro no Cartório de Registro Civil de Pessoas Jurídicas, com prévia aprovação dos atos de constituição pelo Ministério Público.

Tornando-se ilícita, impossível, inútil a finalidade de uma fundação, ou se vencido o prazo de sua existência, o Ministério Público ou qualquer interessado poderá promover sua extinção, incorporando o seu patrimônio, salvo disposição em contrário no ato constitutivo, a outra fundação que se proponha a fim igual ou semelhante. Tornando-se impossível a manutenção ou funcionamento da fundação, quer por falta de recursos materiais, quer por falta de órgãos de administração, impositiva é a declaração de sua extinção.

Já as associações que dependam da reunião de duas ou mais pessoas necessitam para sua regular constituição de: (i) ata da reunião que deliberou pela instituição da entidade, na qual constará o nome dos associados instituidores e as finalidades da entidade; (ii) estatuto que regerá a pessoa jurídica; (iii) registro de todos os atos acima mencionados no Cartório de Registro Civil das Pessoas Jurídicas, onde deverão ser apresentadas duas vias da documentação (art.121 da

\footnotetext{
${ }^{50}$ Arts. 46 e 54 do Código Civil.

${ }^{51}$ Arts. 46 e 53 do Código Civil e art. 120, da Lei 6.015, de 31 de dezembro de 1973.
} 
LRP); (iv) no caso de pessoas jurídicas de direito público, será necessária prévia autorização legislativa.

Uma associação pode ser dissolvida por deliberação de sua Assembleia Geral, sendo que o remanescente do seu patrimônio líquido será destinado à entidade de fins não econômicos designada no estatuto, ou à instituição municipal, estadual ou federal, de fins idênticos ou semelhantes. Na ausência dessas instituições, o que remanescer do seu patrimônio se devolverá à Fazenda do Estado, do Distrito Federal ou da União. Se assim prever o Estatuto ou por deliberação dos associados, estes podem se restituir das contribuições que tiverem prestado ao patrimônio da associação antes da destinação do patrimônio remanescente.

Os estrangeiros também têm plena liberdade de associação assegurada pela Constituição Federal e pelo Estatuto do Estrangeiro ${ }^{52}$, podendo se associar para fins culturais, religiosos, recreativos, beneficentes ou de assistência, filiarem-se a clubes sociais e desportivos e a quaisquer outras entidades com iguais fins, bem como participarem de reuniões comemorativas de datas nacionais ou acontecimentos de significação patriótica, sendo-lhes vedada apenas a atividade política no Brasil e liberada aquela que seja restrita a compatriotas e vinculadas a programas ou normas de ação de partidos políticos do país de origem.

Caso uma associação brasileira seja constituída por mais da metade de associados estrangeiros, somente poderá funcionar mediante autorização do Ministério da Justiça. Já as entidades estrangeiras constituídas em outro país podem funcionar no Brasil mediante cadastro e autorização de funcionamento pelo Ministério da Justiça, devendo ter um endereço de sede e um representante residente no Brasil.

Em respeito à liberdade constitucional, as leis brasileiras não trazem padrões rígidos de enquadramento das OSC, tampouco registros unificados ou autorizações para seu funcionamento. Todavia é característico das organizações da sociedade civil administrar recursos destinados por terceiros a uma finalidade de interesse coletivo. Por essa razão, portanto, a governança e a prestação de contas dessas entidades devem ser transparentes e informativas. Quando recebem ou administram

52 Lei n. 6.815/1980, art. 107 e seguintes. 
recursos destinados pela Administração Pública, esta preocupação deve ser redobrada.

Iniciativas ligadas à governança das organizações justamente buscam adequar o necessário equilíbrio entre a conciliação do interesse público e o interesse privado existente em toda instituição, por meio de princípios que se adaptem à finalidade e às práticas das organizações. ${ }^{53}$

Outro fator a ser considerado sobre a configuração jurídica das OSC é a existência de uma série de cadastros em órgãos públicos, nos diferentes níveis de governos e áreas de atuação, que servem para finalidades distintas. Por exemplo, apenas para citar as mais conhecidas em nível federal, as OSC podem buscar as seguintes inscrições, títulos e certificados: Cadastro Nacional de Entidades (Ministério da Justiça), Organização da Sociedade Civil de Interesse Público (Oscip), Organização Estrangeira (OE), Declaração de Utilidade Pública Federal; registros em diferentes Conselhos de Políticas Públicas na esfera federal e nas diversas áreas.

Tais registros acabam segmentando as OSC a partir de um reconhecimento feito pelo Estado, que as classifica padronizando e supervisionando a atuação das entidades que buscam algum tipo de relacionamento com o Estado, seja para fins de reconhecimento (honorífico), participação em política pública (notadamente os conselhos), financiamento público (seja por contrato, instrumento de cooperação ou subsídio) ou desoneração tributária (incentivo fiscal, isenções e/ou imunidade).

A seguir, selecionamos os quatro mais conhecidos títulos e certificados existentes em âmbito federal que podem ser requeridos pelas OSC no Brasil, a respeito dos quais destacamos as principais características.

\footnotetext{
${ }^{53}$ INSTITUTO BRASILEIRO DE GOVERNANÇA CORPORATIVA - IBGC E GRUPO DE INSTITUTO FUNDAÇÕES E EMPRESAS, GIFE. Guia das melhores práticas de governança para fundações e institutos empresariais. 2.ed. São Paulo, SP: GIFE, 2014.
} 


\subsubsection{Utilidade Pública Federal (UPF)}

Criado pela Lei oㅡ 91/35, regulamentada pelo Decreto $n^{\circ}=50.517 / 61^{54}$; a organização deve ter os objetivos de promoção da educação, da investigação científica, cultura ou filantropia e:

- estar devidamente registrada como pessoa jurídica;

- ser entidade brasileira;

- ter comprovada atuação de interesse público por mais de três anos;

- não remunerar seus diretores, sob quaisquer circunstâncias, nem distribuir entre quaisquer de seus membros ou participantes, conselheiros, diretores, empregados ou doadores eventuais excedentes, receitas, dividendos, bônus, e/ou ativos; e

- publicar um balanço e demonstração de resultados a cada ano.

Além disso, para manter sua regularidade cadastral, a entidade de utilidade pública deve apresentar um relatório anual sobre suas atividades ao Ministério da Justiça.

\subsubsection{Organização da Sociedade Civil de Interesse Público (OSCIP)}

Criada pela Lei $n^{09} .790 / 99^{55}$ e regulamentada pelo Decreto $n^{0} 3.100 / 99^{56}$, a qualificação de Organização da Sociedade Civil de Interesse Público - OSCIP admite que as organizações que busquem este certificado desenvolvam um amplo rol de atividades de interesse público:

- promoção da assistência social;

- promoção da cultura, defesa e conservação do patrimônio histórico e artístico;

\footnotetext{
${ }^{54}$ BRASIL. Decreto n. 50.517, de 2 de maio de 1961. Lei n. 91, de 1935. Regulamenta a Lei n. 91, de 28 de agosto de 1935, que dispõe sobre a declaração de utilidade pública.

${ }^{55}$ BRASIL. Lei n. 9.790, de 23 de março de 1999.

${ }^{56}$ Decreto n. 3.100 , de 30 de junho de 1999.
} 
- promoção gratuita da educação, observando-se a forma complementar de participação das organizações de que trata esta lei;

- promoção gratuita da saúde, observando-se a forma complementar de participação das organizações de que trata esta lei;

- promoção da segurança alimentar e nutricional;

- defesa, preservação e conservação do meio ambiente e promoção do desenvolvimento sustentável;

- promoção do voluntariado;

- promoção do desenvolvimento econômico e social e combate à pobreza;

- experimentação, não lucrativa, de novos modelos socioprodutivos e de sistemas alternativos de produção, comércio, emprego e crédito;

- promoção de direitos estabelecidos, construção de novos direitos e assessoria jurídica gratuita de interesse suplementar;

- promoção da ética, da paz, da cidadania, dos direitos humanos, da democracia e de outros valores universais; e

- estudos e pesquisas, desenvolvimento de tecnologias alternativas, produção e divulgação de informações e conhecimentos técnicos e científicos que digam respeito às atividades acima mencionadas.

As OSCIP podem remunerar seus dirigentes, sem qualquer impedimento à fruição de benefícios fiscais, desde que a remuneração não exceda ao limite estabelecido para a remuneração do Poder Executivo Federal e seja mediante vínculo de emprego ${ }^{57}$. Essas entidades comprometem-se também com normas de governança e práticas de gestão administrativa, necessárias e suficientes a coibir a obtenção, de forma individual ou coletiva, de benefícios ou vantagens pessoais, em decorrência da participação no respectivo processo decisório. Ademais, para manter sua regularidade cadastral, a entidade de utilidade pública deve apresentar um relatório anual sobre suas atividades ao Ministério da Justiça.

${ }^{57}$ Art. 34 da Lei 10.637/2002. 
A lei das OSCIP também estabeleceu uma forma especial de parceria denominada "Termo de Parceria", instrumento jurídico específico para uma OSCIP poder receber recursos públicos, regido por regras próprias, para execução de projetos de cooperação entre OSCIP e o Estado.

\subsubsection{Certificado de Entidade Beneficente de Assistência Social (CEBAS)}

Criado pela Lei № 8.742/93, o Certificado de Entidade Beneficente de Assistência Social - CEBAS, é hoje regulado pela Lei № 12.101/09, regulamentada pelo Decreto no 7.237/10. Podem ser declaradas como Entidade Beneficente de Assistência Social as organizações sem fins lucrativos que prestam serviços gratuitos (total ou parcialmente) nas áreas da assistência social, saúde ou educação a pessoas carentes. A qualidade de beneficente de assistência social da entidade é certificada, respectivamente, pelo Ministério do Desenvolvimento Social e Combate à Fome (MDS), Ministério da Saúde (MS) e Ministério da Educação (MEC), conforme a área de atuação preponderante da organização. Para receber a certificação, a entidade deve cumprir os requisitos estabelecidos na Lei 12.101/2009 e obedecer à regulamentação específica de cada um dos Ministérios.

De posse da certificação, a entidade poderá usufruir de isenção das contribuições sociais, como é o caso da cota patronal da contribuição previdenciária sobre a folha de pagamento (INSS), do COFINS (Contribuição para o Financiamento da Seguridade Social), do PIS/PASEP, e da CSLL (Contribuição Social sobre o Lucro Líquido).

O Cebas é, em outras palavras, pré-requisito para concessão administrativa da "isenção" de contribuições sociais, prevista no $\S 7^{\circ}$ do art. 195 da Constituição da República Federativa Brasileira, exclusivo para entidades com atendimento com gratuidade a pessoas carentes nas áreas da assistência social, saúde e educação.

Para ter direito à certificação, a OSC interessada deve cumprir os seguintes requisitos:

- ser devidamente registrada como entidade legal em território brasileiro há, pelo menos, 12 meses e fornecer evidências de desenvolvimento 
de atividades de interesse público, durante o último ano fiscal, no momento da aplicação;

- ser registrada no Conselho Nacional de Assistência Social, no caso das entidades de assistência social. Entidades de saúde devem demonstrar que oferecem, pelo menos, $60 \%$ de seus serviços ao Sistema Único de Saúde (SUS). As organizações que desenvolvem atividades educacionais devem demonstrar que, pelo menos, $20 \%$ do seu rendimento anual é destinado à prestação de serviços educacionais gratuitos para a população em geral;

- fornecer evidências de que seus recursos, renda, lucros e resultados operacionais são investidos apenas em território nacional e para avançar seus objetivos sociais;

- não remunerar seus diretores, conselheiros, sócios, direta ou indiretamente, ou distribuir entre quaisquer de seus membros ou participantes, conselheiros, diretores, empregados ou doadores quaisquer excedentes ou receitas (geral ou líquido), dividendos, bônus e/ou ativos, por funções ou atividades que Ihes são atribuídas por sua carta;

- não reter ou receber ativo de qualquer indivíduo ou qualquer organização que não seja considerado de assistência social;

- estabelecer, em sua carta, que, em caso de dissolução, os bens remanescentes devem ser transferidos para outra organização sem fins lucrativos, assegurando a Certificação de Entidade Beneficente de Assistência Social ou a uma entidade de interesse público com objetivos semelhantes; e

- realizar suas atividades sem discriminar qualquer pessoa em qualquer circunstância.

Os Ministérios da Saúde, Educação e Desenvolvimento Social supervisionam as organizações para garantir o cumprimento das condições que deram origem à certificação. Se alguma não conformidade é verificada, a autoridade que concedeu o certificado pode cancelá-lo, tendo a entidade direito de recorrer da decisão. 
Desde 16 de outubro de 2013, conforme a Lei 12.868/2013, as entidades portadoras do CEBAS podem remunerar seus dirigentes, sem qualquer impedimento à fruição de benefícios fiscais, desde que a remuneração não exceda $70 \%$ do limite estabelecido para a remuneração do Poder Executivo Federal (Presidente da República e Ministros do STF) e que a remuneração desses dirigentes corresponda, no máximo, a $70 \%$ do teto previsto para servidores do Executivo federal; e que o valor total pago pela entidade a seus dirigentes não exceda a cinco vezes o valor supracitado.

\subsubsection{Organização Social (OS)}

Criada pela Lei Federal ำ 9.637/98, no âmbito da Reforma do Estado ${ }^{58}$, a qualificação como OS, admite que as organizações que busquem este certificado dediquem-se às seguintes atividades de interesse público:

- Ensino

- Pesquisa científica

- Desenvolvimento tecnológico

- Proteção e preservação do meio ambiente

- Cultura

- Saúde

A Lei $n^{\circ}$ 9.837/98 exige que o Estatuto das OS qualificadas em âmbito federal disponha que seu Conselho seja composto de 20 a 40\% (vinte a quarenta por cento) por membros natos representantes do Poder Público; de 20 a 30\% (vinte a trinta por cento) de membros natos representantes de entidades da sociedade civil; até $10 \%$ (dez por cento), no caso de associação civil, de membros eleitos dentre os membros ou os associados; de 10 a $30 \%$ (dez a trinta por cento) de membros eleitos pelos demais integrantes do conselho, entre pessoas de notória capacidade profissional e reconhecida idoneidade moral; e até $10 \%$ (dez por cento) de membros indicados ou eleitos na forma estabelecida pelo estatuto.

${ }^{58}$ PEREIRA, Luiz Carlos Bresser; GRAU, Nuria Cunill. O público não-estatal na reforma do Estado. Rio de Janeiro: FGV,1999. 
Essas normas de governança foram impostas pela lei às entidades interessadas em se qualificar como OS, num modelo de parceria entre Estado e Organizações da Sociedade Civil, pensado para que essas entidades "absorvessem" ${ }^{59}$ serviços e equipamentos públicos, sem que o Estado perdesse o controle das organizações.

Esta transferência de atividade estatal para as OS traz à Lei 9637/98 características específicas que a distinguem das demais. Referida lei inclusive foi objeto de Ação Direta de Inconstitucionalidade (ADI 1923) proposta pelo PT e pelo PDT, à época da sua publicação, e permanece em vigor até a presente data, estando a ação pendente de decisão final pelo STF.

A lei federal das OS também estabeleceu uma forma especial de parceria denominada "Contrato de Gestão", instrumento jurídico próprio para as relações de cooperação entre OS e o Poder Público.

Às OS também é aplicável o mesmo Art. 34 da Lei 10.637/2002 que para as OSCIP, autorizando-as a remunerar seus dirigentes, sem qualquer impedimento à isenção do Imposto de Renda e à CSSL, desde que a remuneração não exceda o limite estabelecido para a remuneração do Poder Executivo Federal e seja mediante vínculo de emprego. ${ }^{60}$

\subsection{FINANCIAMENTO}

As fontes de financiamento legalmente reconhecidas para as OSC são amplas e irrestritas, não havendo claros impedimentos previstos em leis para o recebimento de determinados recursos pelas associações ou fundações. Contudo, especialmente em nível de normas infralegais, é comum a criação de filtros e condições para acesso a determinados direitos de participação e de financiamento.

$O$ assunto de financiamento das OSC é campo privilegiado para a discussão da ausência de coerência e organização administrativa para o exercício de direitos

${ }^{59}$ A Lei $9.837 / 98$ usa a expressão absorção. O próprio enunciado da lei a descreve da seguinte forma: Dispõe sobre a qualificação de entidades como organizações sociais, a criação do Programa Nacional de Publicização, a extinção dos órgãos e entidades que menciona e a absorção de suas atividades por organizações sociais, e dá outras providências. (grifos nossos) 
por OSC. A legislação e as práticas que tratam das condições para gozo de imunidades e isenções tributárias e para acesso a financiamento público não são adequadas e flexíveis para abarcar os diferentes modelos e tamanhos de organizações de forma a garantir, ao mesmo tempo, sua autonomia e preservar seu caráter de sujeito político. $^{61}$

Entre as principais fontes de financiamento das OSC estão os fundos advindos da cooperação internacional, recursos públicos, doações privadas de pessoas físicas e de empresas, além da geração de receitas próprias, por meio do desenvolvimento de atividades econômicas, com a venda de produtos e serviços.

O financiamento privado por pessoas físicas e jurídicas pode ser feito livremente, não havendo impedimentos na legislação para realização de doações. Já o financiamento público pode ser dar, basicamente, por três modalidades: (i) Contrato $^{62}$ : prestação de serviços pela OSC ao Estado; (ii) Instrumentos de colaboração $^{63}$ : acordos voltados à execução conjunta de atividades de interesse comum; (iii) subvenção ${ }^{64}$ : transferência para instituições de caráter assistencial ou cultural, sem finalidade lucrativa, com o objetivo de cobrir despesas de custeio.

Para financiar os instrumentos de colaboração celebrados entre o Estado brasileiro e as OSC, existem muitos fundos públicos que as OSC podem acessar no Brasil. Todos os Ministérios vinculados ao Governo Federal, assim como as Secretarias Especiais de Direitos Humanos, Igualdade Racial e de Promoção dos Direitos das Mulheres dispõem de mecanismos de financiamento e colaboração

${ }^{61}$ ARMANI, D. Sustentabilidade: desafio democrático. In: FIEGE, H-J. Ongs no Brasil: perfil de um mundo em mudança. Fortaleza: Fundação Konrad Adenauer: 2003.

${ }^{62}$ Lei de Licitações - Lei 8666/93

${ }^{63}$ Convênios, termos de Parceria, Contrato de Gestão, Acordos de Cooperação, entre outros instrumentos.

${ }^{64}$ Decreto n. 93.872/1986 [...].

Art. 58. A cooperação financeira da União a entidade pública ou privada far-se-á mediante subvenção, auxílio ou contribuição (Lei n. 4.320/64, §3odo art. 12).

Art. 59. A subvenção se destina a cobrir despesas de custeio de entidades públicas ou privadas, distinguindo-se como subvenção social e subvenção econômica.

Art. 60. A subvenção social será concedida independentemente de legislação especial a instituições públicas ou privadas de caráter assistencial ou cultural sem finalidade lucrativa.

$\S 1^{\circ}$ A subvenção social, visando à prestação dos serviços essenciais de assistência social, médica e educacional, será concedida sempre que a suplementação de recursos de origem privada aplicados a esses objetivos revelar-se mais econômica (Lei n. 4.320/64, art. 16).

$\S 2^{\circ}$ O valor da subvenção, sempre que possível, será calculado com base em unidades de serviços efetivamente prestados ou postos à disposição dos interessados, obedecidos os padrões mínimos de eficiência previamente fixados (Lei n. 4.320/64, parágrafo único do art. 16). 
pública com organizações da sociedade civil. Em âmbito estadual e municipal, o mesmo também ocorre, com maior ênfase às parcerias realizadas nas áreas de assistência social, saúde e educação, políticas cuja execução deve ser prioritariamente em âmbito local, de acordo com a nossa Constituição Federal.

Toda esta diversidade é bastante positiva. No entanto a multiplicidade de fontes de financiamento de Projetos denota uma ausência de organização administrativa estatal na política de relacionamento com as OSCs, o que dificulta sobremaneira a difusão e o acesso aos recursos. Ressalte-se que não há uma política pública organizada, voltada ao financiamento e fortalecimento das organizações da sociedade civil.

A proliferação de regras e de entendimentos acerca dos requisitos de elegibilidade para uma OSC concorrer a cada uma dessas verbas gera fragmentação do trabalho das OSC, e do impacto de suas ações. Assim, conhecer as diferentes fontes de financiamentos públicos disponíveis para as OSC demanda conhecer os recursos previstos nos orçamentos públicos de cada órgão, bem como as estratégias de implementação da política, além de analisar na prática como ocorre o efetivo financiamento.

A Associação Brasileira de ONGs (Abong) tem realizado importantes estudos e pesquisas sobre os recursos e sustentabilidade das ONGs no Brasil. A pesquisa "Sustentabilidade das ONGs no Brasil - acesso a recursos privados"65 apresenta dados ligados a fundos privados nacionais. O "Estudo sobre o acesso das organizações de defesa de direitos e bens comuns aos Fundos Públicos Federais"66, trata das parcerias com Estado e constata que a falta de um marco regulatório específico contribui para a instabilidade e desorganização das práticas. Este estudo avalia os fundos públicos federais e destaca, entre outros pontos importantes sobre o seu funcionamento, o peso da burocracia sobre as organizações.

Em nível federal, o financiamento de Projetos de OSC se dá por meio da seleção destes Projetos por editais públicos, todos divulgados tanto na página eletrônica da Secretaria como no Portal de Convênios do Governo Federal

\footnotetext{
${ }^{65}$ ABONG. Sustentabilidade das ONGs no Brasil: acesso a recursos privados. Rio de Janeiro: Abong, 2010.

${ }^{66}$ Idem. Estudo sobre o acesso das organizações de defesa de direitos e bens comuns aos Fundos Públicos Federais. Rio de Janeiro: Abong, 2012.
} 
(www.convenios.gov.br). A sua atuação para o financiamento de OSC é definida anualmente em conformidade com as prioridades da política pública nessa área.

Um dos maiores problemas enfrentados é a priorização dos recursos voltados às OSC na execução dos orçamentos públicos, pois é muito comum que, diante de outras necessidades, as verbas inicialmente previstas para estas finalidades não tenha autorização para serem utilizadas. É praxe que o Ministério da Fazenda anualmente determine o contingenciamento de verbas orçamentárias, normalmente, a fim de cumprir metas econômicas e de superávit primário.

Nesse sentido, o já mencionado estudo publicado em 2012, pela ABONG, relata o caso do Decreto 7.680, de 17/02/2012, que cortou $R \$ 55$ bilhões do orçamento aprovado pelo Congresso Nacional de 2012, o que impactou na limitação de $55 \%$ dos recursos aprovados para a Secretaria de Políticas de Promoção da Igualdade Racial - SEPPIR - naquele ano. Esse foi um dos maiores cortes/limitação de gastos estabelecidos naquele ano, justamente em uma das áreas onde os indicadores sociais apontam as maiores desigualdades e déficit de realização de direitos por parte da população negra. Na mesma linha, o Relatório do Conselho Gestor do Fundo de Defesa de Direitos Difusos - CFDD - referente ao ano de 2010, disponível no site do Ministério da Justiça ${ }^{67}$, menciona o contingenciamento das verbas como um dos principais gargalos à efetividade do financiamento, identificando o software adotado pelo governo federal, Sistema de Convênios da União - SICONV, como uma das barreiras.

\subsubsection{Atividades Comerciais e Financeiras}

Como regra geral, as entidades sem fins lucrativos são livres para exercer atividades econômicas, investir no mercado de ações, participar de fusões e aquisições e adquirir o controle de empresas. No entanto há restrições relevantes.

A depender do tipo de organização, da atividade econômica que desenvolva e do montante de recursos que sua atividade econômica movimenta, é possível que o 
exercício dessa atividade seja tributado, na medida em que a própria Constituição Federal estabelece (art. 150, $\$ 4^{\circ}$ ) que o limite da imunidade tributária é adstrito às atividades essenciais das entidades abrangidas pela imunidade.

Em que pese a liberdade existente, em recente decisão, de agosto de 2013, o Supremo Tribunal Federal, se manifestou no julgamento do Recurso Extraordinário 385091/DF, no sentido de considerar a potencial ameaça à livre concorrência na avaliação do limite da imunidade tributária de organizações sem fins lucrativos que desenvolvam atividades econômicas: "a imunidade só pode ser afastada se o Fisco comprovar o descumprimento dos requisitos legais ou se constatar que seu exercício atenta contra outra garantia constitucional, qual seja, a livre concorrência". 68

A decisão acima reconhece a amplitude da imunidade sobre o exercício de atividades econômicas pelas OSC, mas também a sua limitação com relação a outros princípios constitucionais, como o da livre concorrência.

\subsubsection{Controles, Transparência e Obrigação de Prestar Contas}

Qualquer cidadão tem legitimidade para requerer informações relativas às atividades desenvolvidas pelas entidades sem fins lucrativos e à aplicação de seus recursos, reivindicando a transparência decorrente de seu caráter eminentemente público e da cláusula "sem fins lucrativos".

Quando administram patrimônio especificamente destinado a terceiros, o controle social sobre suas atividades e recursos financeiros merece atenção redobrada. Por essa razão, seus processos de governança e prestação de contas devem ser transparentes e informativos, especialmente quando recebem ou administram recursos advindos do orçamento da União, dos Estados, do Distrito Federal ou dos Municípios.

\footnotetext{
68 Recurso Extraordinário 385091/DF-DISTRITO FEDERAL RECURSO EXTRAORDINÁRIO. Relator(a): Min. DIAS TOFFOLI. Julgamento: 06/08/2013. Órgão Julgador: Primeira Turma. Publicação - ACÓRDÃO ELETRÔNICO: DJe-207 DIVULG 17-10-2013 PUBLIC 18-10-2013).

Disponível em: <http://redir.stf.jus.br/paginadorpub/paginador.jsp?docTP=TP\&docID=4690215. Último acesso em 03.12.2013. página 06 - Voto do Ministro Dias Toffoli>. Acesso em 12 de novembro de 2014.
} 
O Ministério da Justiça, órgão responsável por qualificar e acompanhar a atuação das entidades qualificadas como Organização da Sociedade Civil de Interesse Público (OSCIP), declaradas como Utilidade Pública Federal (UPF) e Organizações Estrangeiras (OE), implantou Cadastro Nacional de Entidades Sociais (CNEs). Referido cadastro tem a finalidade de proporcionar maior transparência, sendo obrigatório para as OSCIPs, entidades de UPF e Organizações Estrangeiras, e facultativo para quaisquer entidades que queiram disponibilizar na internet suas informações institucionais.

O Estado de São Paulo, também, instituiu ${ }^{69}$ um cadastro de preenchimento obrigatório para todas as OSC que recebam recursos de origem pública advindos de repasses ou incentivos fiscais no âmbito estadual. Este cadastro é administrado pela Corregedoria Geral do Estado de São Paulo, que também é responsável pela emissão dos Certificados de Regularidade Cadastral de Entidades - CRCE, das organizações nele inscritas. ${ }^{70}$

Já as Promotorias voltadas ao velamento das fundações de diversos estados implantaram o Sistema SICAP, estabelecendo um roteiro para as prestações de contas das fundações e das entidades de interesse social sob a fiscalização do Ministério Público.

Cumpre à sociedade e às organizações monitorarem a adequação e a eficiência desses sistemas, fazendo sugestões de aperfeiçoamento para que se alcance o necessário equilíbrio entre o dever de transparência e prestação de contas e a liberdade de atuação e funcionamento das entidades.

Além das prestações de contas relacionadas a títulos e certificados específicos que as organizações detenham, existe também a prestação de contas específica de cada instrumento de parceria ou financiamento público (ou privado) com a qual a organização se comprometa por meio de instrumentos de natureza contratual que venha a estabelecer.

As exigências das prestações de contas de recursos públicos repassados a OSC variam de acordo com as normas de cada instrumento, a partir da legislação aplicável a cada ente público (União, Estado, DF e Municípios) que o firme na

\footnotetext{
${ }^{69}$ Decreto $57.501 / 2011$.

${ }^{70}$ Resolução CC-6, de 14, publicada do Diário Oficial do Estado de 15/01/2013.
} 
respectiva área de interesse (saúde, direitos humanos e meio ambiente, entre outras).

Nesse contexto, aplicam-se também as normas relativas à probidade administrativa, de acesso à informação e anticorrupção, que têm caráter penal e limitam o exercício de direitos pelas pessoas físicas ou jurídicas.

A Lei 8.429/2002 (Lei de Improbidade Administrativa) prevê sua aplicação com relação a atos de improbidade praticados contra o patrimônio de entes públicos ou privados que recebam subvenção, benefício ou incentivo, fiscal ou creditício, de órgão público. As sanções previstas na lei, que envolvem desde a restituição dos valores que tenham sido desviados, a indenização ao erário público até a perda dos direitos políticos por até oito anos, são aplicáveis também a agentes privados que administrem recursos públicos em OSCs.

Já a Lei Anticorrupção (Lei 12.846/2013) dispõe sobre a responsabilização administrativa e civil de pessoas jurídicas, incluindo fundações, associações de entidades ou pessoas, pela prática de atos ilícitos contra administração pública, nacional ou estrangeira (art. $2^{\circ}$ ). A lei faculta a aplicação de multas administrativas no valor de $0,1 \%$ a $20 \%$ do faturamento bruto anual de uma organização ou, na impossibilidade da utilização desse critério, valores entre $\mathrm{R} \$ 6$ mil e $\mathrm{R} \$ 60$ milhões, sem prejuízo de possível responsabilização judicial, que poderá resultar na perda de bens, suspensão ou interdição parcial de atividades, dissolução compulsória da pessoa jurídica, proibição de receber incentivos, subsídios, doações ou empréstimos de órgãos ou entidades públicas.

\subsubsection{Imunidades e Isenções}

$\mathrm{O}$ art. 150, inciso VI, alínea "c", da Constituição Federal determina que a União, os Estados, Distrito Federal e os Municípios não estão autorizados a tributar a renda, o patrimônio e os serviços de entidades de educação, assistência social e de assistência à saúde constituídas como pessoa jurídica de direito privado, sem fins lucrativos, no que estiver relacionado às atividades essenciais da entidade. Esta imunidade aplica-se também às organizações assistenciais na área da saúde, sem fins lucrativos. 
O art. 14 do Código Tributário Nacional estipula que, para gozo da imunidade, essas entidades devem cumprir os seguintes requisitos:

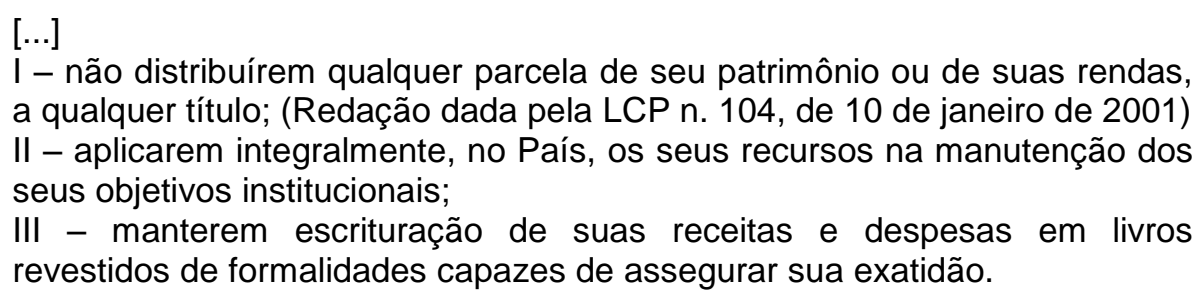

Desde que os requisitos sejam atendidos, a entidade de educação, de saúde ou de assistência social precisam demonstrar seu caráter assistencial para gozarem da imunidade dos impostos federais, estaduais e municipais sobre a renda (IR, federal), (CSSL, federal) patrimônio (ITR, federal), (IPVA, estadual) e serviços (ICMS, estadual), (ISS, municipal), porque a imunidade é regra constitucional que limita o poder de tributar.

Ainda no plano das imunidades constitucionais, o art. 195, §7º, estabelece que as instituições de assistência social, saúde e educação que atuarem de maneira beneficente, na forma da lei, serão imunes às contribuições sociais. Para comprovação do caráter beneficente de suas ações, a organização deve ser certificada com o Certificado de Entidade Beneficente de Assistência Social CEBAS -, de acordo com os requistos estabelecidos na Lei 12.101/09.

Já a isenção é permissão prevista em lei, em situações de interesse geral, que desobriga o recolhimento de tributos em condições específicas. A legislação da federal, estadual e municipal, prevê isenções tributárias possíveis de serem obtidas pelas OSC a depender da competência de arrecadação e regras específicas de cada ente.

\subsubsection{Doações}

As doações podem ser livremente realizadas por pessoas físicas ou jurídicas, nacionais ou estrangeiras, às OSC no Brasil. Como já mencionado, a depender do Estado, sobre ela pode incidir Imposto sobre Doação (ITD, ITCMD, etc.), cuja 
alíquota, no estado de São Paulo, é 4\%, sendo possível buscar a isenção deste tributo por meio de procedimento administrativo específico.

Os incentivos fiscais existentes para doações normalmente exigirão que a OSC beneficiária da doação aplique os recursos recebidos em projetos previamente aprovados pelo Poder Público, nas suas áreas de atuação. A insuficiência de mecanismos de incentivo para a doação privada de recursos livres para as OSC aplicarem como bem entenderem no desenvolvimento de suas atividades é uma das dificuldades hoje enfrentadas pelas OSC no Brasil e esse fato dificulta o seu fortalecimento institucional.

Nesse sentido, classificamos os incentivos a doações em duas espécies: Incentivos a Doações Institucionais e os Incentivos a Doações a Projetos.

\subsubsection{Incentivos a Doações Institucionais}

Neste tipo de doação, só podem ser beneficiárias as OSC que tenham sido previamente qualificadas como OSCIP ou como UPF pelo Ministério da Justiça. Os

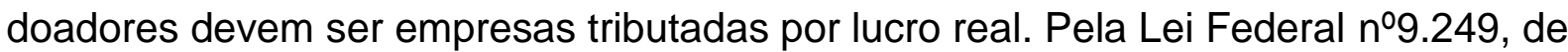
1995, a doação desse tipo permite à empresa fazer a dedução de até $2 \%$ do seu lucro operacional bruto. Este limite dos $2 \%$ deve ser calculado antes do cômputo da própria doação, portanto, diminuindo o imposto de renda e a contribuição social devidos. O investidor deposita os recursos na conta bancária em nome da entidade, e esta Ihe entrega uma declaração oficial, padronizada pela Receita Federal, na qual assume o compromisso de usar os recursos exclusivamente na realização de seus propósitos, inclusive com a designação da pessoa física responsável pelas tarefas. O doador deve guardar o documento para fins de fiscalização.

\subsubsection{Incentivos a Doações a Projetos}

Nesse tipo de doação, exigir-se-á que a OSC beneficiária aplique o recurso recebido integralmente em projetos previamente aprovados pelo Poder Público, nas suas áreas de atuação. Trata-se de incentivo mais vantajoso do ponto de vista de quem doa uma vez que permite a dedução dos valores doados do imposto a pagar, 
e não da base de cálculo do imposto. Constitui hoje importante fonte de recursos para a realização de projetos por OSC. Todavia, o seu caráter limitado, que só permite a aplicação em projetos, de acordo com regras específicas, dificulta o investimento em desenvolvimento da própria instituição, como na estruturação de uma política administrativa ou de recursos humanos, entre outras ações da instituição como um todo, e não apenas dos projetos ${ }^{71}$.

A legislação aplicável aos Projetos das Leis de Incentivo sofre forte influência das normas administrativas que regulam os instrumentos de contratualização, que hoje são objeto de questionamento e revisão, eleitas como maiores prioridades do Marco Regulatório das OSC. O que se observa, portanto, é tendência de reprodução dos mesmos formalismos e equívocos de interpretação que existem na análise dos convênios e de outras modalidades de relações de parceria.

\footnotetext{
${ }^{71}$ Fundo Municipal da Criança e do Adolescente (Fumcad) - Lei no8.069/90; Fundo Nacional do Idoso - Lei no10.741/03; Lei Federal de Incentivo à Cultura ou Lei Rouanet - Lei $n \cong 8.313 / 91$; Lei Federal de Incentivo ao Esporte - Lei no11.438/06; Programa Nacional de Apoio à Atenção da Saúde da Pessoa com Deficiência (Pronas/PCD) - Lei no12.715/2012.
} 


\section{ANÁLISE DA LEGISLAÇÃO SOBRE ORGANIZAÇÕES DA SOCIEDADE CIVIL PÓS-CONSTITUIÇÃO DE 1988}

\subsection{FASES DISTINTAS: REDEMOCRATIZAÇÃO, PARTICIPAÇÃO, CONTRATUALIZAÇÃO, CONTROLE E ORGANIZAÇÃO}

Desde a promulgação da Constituição Federal, o Estado brasileiro ampliou a esfera de interação com as organizações da sociedade civil, sendo possível destacar quatro fases distintas sob o ponto de vista da criação de normas voltadas ao tratamento das relações entre Estado e OSCs: (i) redemocratização; (ii) participação; (iii) contratualização; (iv) controle e (v) organização.

A fase da redemocratização consistiu num período de efetivação da garantia dos direitos à liberdade de criação e de atuação das organizações da sociedade civil nessas entidades, ocorrida durante as décadas de 1980 e 1990. Para assegurar a necessária liberdade de reunião pacífica e liberdade de associação, o texto da Constituição Federal de 1988 previu, em seu art. 5º, inciso XVIII, a não interferência estatal na criação, funcionamento e auto-organização dessas organizações. E dessa forma traz garantia ao livre exercício de direitos civis e políticos, em que o bem jurídico tutelado é o direito público subjetivo de cada cidadão em participar de atividades lícitas voltadas à finalidade que bem lhe entender. Trata-se da liberdade de associação, equiparável à liberdade de pensamento, de expressão e de informação.

Já a fase da participação inicia-se com a previsão constitucional de participação e controle social de representantes de organizações da sociedade civil no processo de elaboração, implementação e avaliação de políticas públicas no ano de 1988. A Constituição trata da participação ao dispor sobre planejamento municipal (art. 29, XII), usuários dos serviços públicos (art. 37, §3); seguridade social (art. 194, parágrafo único, VII); saúde (art. 198, III - CF); educação (art. 205); proteção do patrimônio cultural brasileiro (art. 216, §1); e do meio ambiente (art. 225); assistência social (art. 204), criança e do adolescente (art. 227, §7), entre outros. 
Nas diferentes leis estruturantes de políticas públicas, esses espaços de participação que a Constituição previu foram regulamentados na década de 1990, , especialmente na sua primeira metade, como é o caso do Estatuto da Criança e do Adolescente (Lei 8.069/90), da LOAS - Lei Orgânica da Assistência Social (Lei 8.742/93); da Lei Rouanet (Lei 8313/91) e ainda da Lei de Recursos Hídricos (Lei 9.433/97); Lei das Telecomunicações (Lei Nacional de Telecomunicações - Lei 9.472/97); entre outras.

Esta implementação tem se dado com a crescente presença e atuação da sociedade civil em Conselhos de Políticas Públicas, que, mesmo com todos os desafios de uma efetiva participação, apresenta-se como mecanismos de grande importância no controle social das políticas de gestão pública, proporcionando a democratização do conhecimento de tais políticas e a difusão de informação pública pretendida pela Constituição Federal.

Por seu turno, a fase da contratualização caracteriza-se pela maior produção de normas voltadas à regulamentação das relações jurídicas revestidas na forma contratual entre organizações da sociedade civil e o Estado. Tem seu termo inicial em meados da década de 1990, com a Reforma do Estado ${ }^{72}$, que, ao estabelecer a transferência de atividades não exclusivas do Estado, como saúde e educação, para entidades sem fins lucrativos, estimulou a "parceirização" com entidades da sociedade civil para a prestação de serviços públicos, ou de relevância pública.

Nas palavras do professor José Eduardo Sabo Paes ${ }^{73}$, "[a] ampliação das funções do Estado, a complexidade, a falta de estrutura e de condições para, com eficácia, cumprir suas atribuições fizeram com que o próprio Estado estabelecesse novas formas de e meios de prestação eficiente de seus serviços e atribuições."

Neste contexto destaca-se a articulação liderada pela então primeira dama, Profa. Ruth Cardoso, no Conselho Comunidade Solidária, em que se discutiu e se elaborou um programa para ampliação da participação das OSC na execução de políticas públicas em parceria com o Estado, cujo principal resultado foi a edição da

\footnotetext{
${ }^{72}$ PEREIRA, Luiz Carlos Bresser; GRAU, Nuria Cunill. O público não-estatal na reforma do Estado. Rio de Janeiro: FGV, 1999.

${ }^{73}$ Paes, José Eduardo Sabo. Fundações, Associações e Entidades de Interesse Social:Aspectos jurídicos, administrativos, contábeis, trabalhistas e tributários. 6. ed. Brasília: Brasília Jurídica, 2006, p. 686-687.
} 
Lei das OSCIP - Organizações da Sociedade civil de Interesse Público, Lei 9.790/99.

Durante esta fase foram editadas a Lei 9.637/98 (Lei das Organizações Sociais) e a Lei 9.790/99 (Lei das OSCIPs), criando instrumentos jurídicos de contratualização talhados para as referidas relações de cooperação entre o Estado e as organizações da sociedade civil - o Contrato de Gestão e o Termo de Parceira, respectivamente.

A fase caracterizada pelo controle se inicia com o Acórdão 1070/2003 do Tribunal de Contas da União, que recomendou a alteração do art. 27 IN 01/97, que à época regulamentava a execução dos Convênios da União com as OSCs, impondo às entidades privadas sem fins lucrativos o dever de seguir os estritos termos da Lei 8.666/93 no uso dos recursos repassados por convênios.

A medida foi seguida pelo Decreto ํㅜ 5.504, de 05 de agosto de 2005, que reafirmou a obrigatoriedade de licitação, preferencialmente na modalidade de pregão eletrônico e a estendeu também às OSCIP e OS, passando por cima das especificidades destes modelos, cujas leis prevêem a utilização de regulamentos próprios de compras e contratações.

A imposição da Lei de Licitações a entidades privadas escancara a absoluta ausência de um planejamento público estatal para as ações de fomento e colaboração com as OSCs.

Dois anos depois, o Decreto 6.170, de 25 de julho de 2007, estabeleceu o mecanismo de cotação prévia para contratação de produtos e serviços por entidades privadas no âmbito do convênio, bem como a criação do Sistema de estão de Convênios - SICONV -, no âmbito do Ministério do Planejamento, Orçamento e Gestão - MPOG. Posteriormente, foi editada uma série de Portarias Interministeriais voltadas à que regulamentação do SICONV - Sistema de Convênios com a União, essencialmente voltadas às prestações de contas, com ênfase no controle do Estado sobre as parcerias.

O ápice da fase de controle e deu com a suspensão pelo Decreto $n^{-}$ $7.568 / 2011$, por 30 dias, dos repasses a todas as entidades privadas sem fins lucrativos, determinada pela Presidente Dilma Rousseff, por ocasião da constatação de problemas envolvendo denúncia de desvio de recursos por meio de convênios 
com ONGs de fachada integrantes de um esquema criminoso de desvio de recursos públicos.

A ampliação do viés controlador tem os seus efeitos negativos reforçados com relação às OSC a partir de uma prática comum no Direito Administrativo brasileiro, que consiste na ideia do "regime único", que é tendência de submeter as relações jurídicas que envolvam o Estado, de forma irrefletida, a um único regime de Direito Administrativo. Esta tendência seria mesmo uma verdadeira mazela que assola a nossa Administração Pública, uma verdadeira "maldição do regime único", conforme a precisa e bem humorada crítica do professor Floriano de Azevedo Marques Neto sobre o tema. ${ }^{74}$

Impor normas típicas de entidades de direito público às OSC destinatárias de financiamento público (bem como suspender o repasse a todas as OSC, generalizando a desconfiança), revela o tratamento inadequado e um forte viés controlador do Estado brasileiro para com as OSC. Nestas situações, fica clara uma escolha política mais interessada em transmitir uma percepção pública de moralização dessas relações do que efetivamente melhorá-las.

Paradoxalmente, o mesmo Decreto $\mathrm{n}^{-}$7.568/2011, que marca o auge do controle inicia um novo momento na produção de normas que tratam das relações entre Estado e OSC no Brasil. O mencionado Decreto instituiu um Grupo de Trabalho formado por representantes de órgãos públicos e de organizações da sociedade civil, ${ }^{75}$ destinado a propor alterações legislativas ao denominado "Marco Regulatório das Organizações da Sociedade Civil".

Os trabalhos deste Grupo resultaram em propostas que influenciaram de forma positiva o cenário, proporcionando o diálogo entre Estado e OSC com vistas a

${ }^{74}$ MARQUES NETO, Floriano Peixoto de Azevedo . Do Contrato Administrativo à Administração Contratual. Revista do Advogado, v. 107, p. 74-82, 2009. P. 77.

${ }^{75}$ Durante a campanha presidencial que antecedeu a eleição de Dilma Rousseff, um conjunto de organizações da sociedade civil e movimentos bastante representativos do segmento das OSC no Brasil reuniram-se numa articulação em torno de um novo marco regulatório para essas entidades: a Plataforma por um Novo Marco Regulatório para as Organizações da Sociedade Civil. Esta Plataforma conseguiu o compromisso da então candidata à Presidência da República com alterações no Marco Regulatório das Organizações da Sociedade Civil brasileira, a partir do diagnóstico de que o ambiente jurídico institucional, apesar de assegurar liberdades e participação, não promove o desenvolvimento ou o fortalecimento dessas entidades. O Grupo de Trabalho instituído pelo Decreto buscou nessa Plataforma das OSC indicações de entidades para integrá-lo. 
buscar o aperfeiçoamento das relações de contratualização, mas também da legislação geral voltada às OSCs.

Esta nova fase é marcada pela busca da organização administrativa com vistas a estruturar o relacionamento do Estado com as OSCs, o estudo, o real diagnóstico da situação das OSC e a elaboração de propostas cuja base conceitual fundamentou-se no respeito ao direito de liberdade de associação.

A organização administrativa e o princípio da confiança do administrado na Administração Pública são típicos de uma Administração que se reformula para garantir os direitos fundamentais dos cidadãos. Nos dias de hoje, ganham maior relevância, ao estruturar a atuação do Estado e aproximar os conceitos de liberdade e autoridade. ${ }^{76}$

A fase voltada à organização administrativa, que se iniciou no final de $2011 \mathrm{e}$ vai até os dias atuais, destaca-se pela estruturação do Programa do "Marco Regulatório das Organizações da Sociedade Civil", pela Secretaria Geral da Presidência da República. Este programa apontou a necessidade de a Administração Pública aprofundar o conhecimento sobre o universo das OSCs, preservando a autonomia e a independência das organizações, como agentes da sociedade, importantes para o desenvolvimento.

Antes de tratarmos de forma mais pormenorizada do referido Programa, cabe aprofundar o conhecimento da realidade das chamadas relações de contratualização, considerando a importância a elas conferida neste cenário.

\subsubsection{Diagnóstico das Relações de Contratualização}

Em estudo elaborado pelo NEATS/PUC-SP - Núcleo de Estudos Avançados em Terceiro Setor da PUC-SP sobre a modernização do sistema de convênios entre o Estado e as OSCs ${ }^{77}$, entre os anos de 2011 e 2012, há um claro diagnóstico de

${ }^{76}$ SANTOS NETO, João Antunes dos. O Impacto dos Direitos Humanos Fundamentais no Direito Administrativo. Belo Horizonte: Fórum, 2008, p. 415.

${ }^{77}$ Relatório da Pesquisa sobre a Modernização do Sistema de Convênios entre a Administração e Organizações da Sociedade Civil, elaborada pelo NEATS da PUC/SP - para o Projeto Pensando o Direito, desenvolvido em parceria entre o Ministério da Justiça e o PNUD: JUNQUEIRA, Luciano Prates et alli. Modernização do sistema de convênio da Administração Pública com a sociedade civil. Brasília: Ministério da Justiça, 2012. (Série Pensando o Direito). v. 41. p. 37. Disponível 
que o dia-a-dia das OSC no Brasil é caracterizado por diversas barreiras burocráticas e cadastrais que dificultam ou impedem seu fortalecimento e o acesso a financiamento público e privado.

O documento contém detalhada coletânea da legislação, análise de jurisprudência do TCU sobre convênios e parcerias, além de entrevistas e oficinas, com cerca de 50 organizações e 20 servidores públicos federais, entre controladores e gestores públicos, além de propostas práticas de alterações para modernização do SICONV - Sistema de Convênios da União, organizadas a partir de suas etapas (Chamamento Público, Credenciamento, Cadastramento do proponente, Cadastramento de proposta, Abertura da Conta Bancária, Contratação de Bens e Serviços, Realização de Pagamentos e Prestação de Contas).

O estudo revela que, em razão do atual marco regulatório inadequado, acessar recursos públicos no Brasil é fator de vulnerabilização para muitas OSCs. Identifica, ainda, a origem histórica do convênio de instrumento típico da regulamentação de acordos entre entes federativos, como uma das principais causas de problemas na execução desses instrumentos, ao estender inadvertidamente normas típicas do regime jurídico de direito público a organizações privadas sem fins lucrativos que atuam em cooperação com o Estado ${ }^{78}$.

Propõe que os seguintes fatores são determinantes para a utilização de analogias indevidas e insegurança com elação aos convênios: (I) ausência de regulamentação do convênio com a sociedade civil em nível legal; (ii) ocorrência de sucessivas alterações nas normas regulamentadoras; multiplicidade de objetos dos convênios; (iii) dissenso doutrinário sobre a natureza do instrumento e normas incidentes; e (iv) planejamento público insatisfatório para celebração desses instrumentos.

É interessante comparar este estudo com o relatório publicado pelo Grupo de Trabalho sobre o Marco Regulatório das Organizações da Sociedade Civil, criado pela Secretaria Geral da Presidência da República, publicado em agosto de 2012, em que a insegurança jurídica é identificada como uma das principais características

em:<http://participacao.mj.gov.br/pensandoodireito/wp-content/uploads/2013/03/Volume-41.pdf>. Acesso em: 02 de novembro de 2014.

${ }^{78}$ Op. cit. 
dos convênios, com o uso de "analogias indevidas", "planejamento precário pelo poder público", a "dificuldade de acesso ao Estado" e a "ausência de dados atualizados sobre as OSCs". Dentro das atividades desenvolvidas, o Grupo de Trabalho opinou pela inadequação do atual ambiente jurídico-institucional das OSC no Brasil e propôs um Anteprojeto de Lei, que foi entregue juntamente com relatório ${ }^{79}$ à Presidente Dilma Rousseff.

Esse trabalho foi determinante para a criação de um importante processo voltado à reestruturação das relações entre o Estado brasileiro e as OSCs, sediado pela Secretaria Geral da Presidência da República, que se destacou com consistente projeto público voltado à criação de uma política pública dirigida às OSC no Brasil.

\subsection{O PROGRAMA DO MARCO REGULATÓRIO DAS ORGANIZAÇÕES DA SOCIEDADE CIVIL - MROSC}

A tarefa de estruturar um ambiente jurídico-institucional mais favorável ao desenvolvimento das organizações da sociedade civil não é simples e esbarra em entraves das mais diversas ordens, como os diferentes perfis de organizações, normas fiscais e orçamentárias, além das naturais tensões e disputas inerentes às eleições entre sociedade civil e Estado.

Uma das características do trabalho realizado entre os anos de 2012 e 2014 pelo Programa do Marco Regulatório é a abrangência temática e acuidade técnica dos estudos e propostas para elaboradas para a melhoria do ambiente jurídico institucional para as OSC no Brasil.

Para dar conta da amplitude do tema com a profundidade necessária, a equipe técnica da Secretaria Geral da Presidência da República escolheu atuar em duas diferentes perspectivas: Uma perspectiva normativa e uma perspectiva de conhecimento. A primeira (normativa) visa à alteração e a criação de leis e de outras

\footnotetext{
${ }^{79}$ Fonte: Relatório do Grupo de Trabalho sobre o Marco Regulatório das Organizações da Sociedade Civil, criado pela Secretaria Geral da Presidência da República para elaborar propostas voltadas ao aperfeiçoamento de relações de parceria entre organizações da sociedade civil e entidades sem fins lucrativos, agosto de 2012, p. 23. Disponível em: <http://www.secretariageral.gov.br/mrosc/historico1/relatorio>. Acesso em: 23 de novembro de 2014.
} 
normas infralegais necessárias para o aperfeiçoamento normativo. Já a segunda perspectiva (de conhecimento) envolve também a realização de capacitação, informação, estudos, pesquisas e disseminação de informações relacionadas ao universo das organizações da sociedade civil.

Foi assim que o Programa do Marco Regulatório das OSC iniciou a formação de uma agenda pública para a pauta das OSCs, em permanente diálogo e interação entre representantes de diferentes áreas do governo, dos órgãos de controle e arrecadação, OSCs, estudiosos, advogados, com a realização de encontros e discussões, incluindo a realização de dois seminários internacionais sediados em Brasília, assumindo o papel do Estado como agente organizador de uma política de fomento e de colaboração com as organizações da sociedade civil $^{80}$.

Esses elementos proporcionaram aprofundamento, intercâmbio e alinhamento de informações, constituindo um rico espaço de capacitação mútua e ampliação do entendimento, o que propiciou a elaboração de propostas mais viáveis de serem implementadas.

Entre as principais alterações legislativas realizadas a partir do programa do Marco Regulatório das OSCs, duas chamam a atenção pela importância e por atenderem demandas históricas das organizações da sociedade civil e dos estudiosos da matéria. A primeira delas é a questão da remuneração de dirigentes de organizações da sociedade civil (Lei 12.868/2013), e a segunda diz respeito à regulamentação das relações de parceria entre OSC e a Administração Pública, que resultou na aprovação da Lei nº13.019/2014, pelo Congresso Nacional.

Sem dúvida, a continuidade do processo iniciado pelo programa do MROSC, será determinante para a criação de uma nova cultura administrativa pública apta a interpretar e reger as relações entre as organizações e o Poder Público, a partir da aprovação da Lei 13.019/2014, nova lei geral de parcerias entre as OSC e a Administração, que entrará em vigor em julho de 2015, conforme previsto pela Medida Provisória MP 658, de 29 de outubro de 2014, que alterou o prazo de início da vigência, inicialmente, previsto para 1ํ de novembro de 2014.

\footnotetext{
${ }^{80}$ LOPES, L. C. F. As parcerias entre o Estado e as Organizações da Sociedade Civil no Brasil: a formação de uma agenda de mudança institucional e regulatória. In: NOVENA CONFERÊNCIA REGIONAL THE INTERNATIONAL SOCIETY FOR THIRD-SECTOR RESEARCH. Santiago do Chile: 28-30 de agosto 2013.
} 


\section{DESAFIOS DAS ORGANIZAÇÕES DA SOCIEDADE CIVIL NO BRASIL}

Os desafios atualmente enfrentados pelas organizações da sociedade civil no Brasil são muitos e suas razões podem ser compreendidas a partir de elementos dos cenários nacional e internacional.

Como se sabe, mais necessária que a justificação, os direitos humanos precisam hoje de instrumentos políticos e jurídicos para sua proteção e efetivação. ${ }^{81}$ Nesse sentido é que se propomos abordar a seguir os principais desafios que hoje se colocam para a efetivação do direito de liberdade de associação relativo às organizações da sociedade civil no Brasil.

Do ponto de vista do Direito e visando à identificação e sistematização dessas dificuldades, voltadas para a busca de seu enfrentamento e superação, é possível afirmar que o tratamento estatal das OSC deve partir do reconhecimento e da preservação dos dois principais aspectos jurídicos de suas identidades.

Estes aspectos, que trabalhamos nos primeiros Capítulos deste trabalho, são os relativos aos cinco elementos que as caracterizam e às três dimensões do direito de liberdade de associação relacionadas às OSCs.

Como já analisado, é dever constitucional do Estado brasileiro garantir a Liberdade de Associação, zelando pelo direito das Organizações da Sociedade Civil atuarem livremente, agirem e manifestarem-se. É, também, dever do Estado se relacionar com essas organizações, criar espaço para a sua participação, identificar e difundir as boas iniciativas que contribuam para o desenvolvimento da sociedade, inclusive por meio de financiamento público.

Reconhecer essas três dimensões integrantes da liberdade de associação envolve não apenas respeitar o exercício dessa liberdade, mas assegurar que seja colocada em prática através do estímulo ao direito ao desenvolvimento, da educação para a cidadania e do respeito ao valor existente na diversidade e na experimentação livre de iniciativas pelos indivíduos. O Estado que capta apropriadamente as inovações sociais tem ótima oportunidade de propor e

${ }^{81}$ BOBBIO, Noberto. A Era dos Direitos. 8. ed. Rio de Janeiro: Campus, 1992. 
programar políticas públicas mais adequadas às pessoas e localidades, atuando como depositário e difusor das boas iniciativas da sociedade.

Aspecto prioritário é o respeito aos direitos de personalidade e os aos direitos fundamentais da pessoa jurídica "organização da sociedade civil", com a prevalência aos cinco elementos que conceituam as OSCs, na qualidade de princípio, voltado à garantia da liberdade de associação e não interferência estatal em seu funcionamento.

Reconhecer os direitos fundamentais e os aspectos inerentes ao direito de personalidade das pessoas jurídicas sem fins lucrativos - associações e fundações certamente ajudará a determinar as bases mínimas de identidade e dignidade no tratamento dessas instituições essenciais para a democracia.

Alguns aspectos relacionados à criminalização de instituições de direitos humanos já são conhecidos e tem conexão com violências sofridas pelos indivíduos que as compõem. No entanto há também aspectos de direito civil, de direto administrativo e tributário que, analisados sob este prisma, criam situações burocráticas que constituem barreiras à regular existência e ao financiamento dessas entidades.

Diante disso, no âmbito de sociedades democráticas, é necessário lidar com esses obstáculos na perspectiva de garantir às OSC o seu direito de existir, de adquirir sua personalidade jurídica e de ter assegurada a sua capacidade legal para, enquanto agentes de transformação que são, agir em prol do desenvolvimento.

É matéria relevante para o desenvolvimento das OSC o reconhecimento dessas entidades como sujeitos de direito merecedores de proteção especial, seja diante da sua importância para a democracia, em razão da constatação do tratamento não isonômico a que vêm sendo submetidas, quando comparadas a outras espécies de pessoas jurídicas, inclusive a empresas com finalidade lucrativa.

\subsection{ELEMENTOS CARACTERIZADORES DAS OSC COMO REQUISITO PARA A "CIDADANIA PLENA"}


Como já observado ao tratar do elemento "sem fins lucrativos" das organizações da sociedade civil, a caracterização de uma OSC por essa dimensão negativa deve ser interpretada sob a ótica do princípio da liberdade de associação.

As OSC devem ter preservada a prerrogativa de administrar as suas atividades e realizá-las da forma que considerarem mais eficientes para atingir os seus objetivos sociais.

Chama a atenção como o conceito "sem fins lucrativos" vem sendo aplicado por determinadas autoridades públicas que impõem às OSC um nível de detalhamento na exigência de comprovação do caráter não lucrativo de sua finalidade, que (não seria demais dizer) impõe à organização verdadeira inversão da presunção de inocência.

Há casos em que agentes públicos manifestam-se contrariamente determinado tipo de atividade desenvolvida por uma OSC, com fundamento na sua percepção pessoal sobre o que a instituição "deveria" fazer para melhor alcançar o interesse público a que se propõe.

Um caso em que esse tipo de desvio pode ser claramente identificado é o dos chamados fundos patrimoniais, ou endowmnents, que são "estruturas que recebem e administram bens e diretos, majoritariamente recursos financeiros, que são investidos com os objetivos de preservar o valor do capital principal no longo prazo, inclusive contra perdas inflacionárias, e gerar resgates recorrentes e previsíveis para sustentar financeiramente um determinado propósito, uma causa ou uma entidade de interesse". 82

Conforme mencionado em estudo elaborado pelo IDIS - Instituto para o Desenvolvimento do Investimento Social, sobre fundos patrimoniais, "no caso das associações e fundações brasileiras, existem obstáculos que dificultam a disseminação dos fundos patrimoniais" ${ }^{83}$ Na prática, esta dificuldade se origina da equivocada interpretação por parte de agentes da fiscalização de que a obrigação legal de "aplicarem integralmente, no País, os seus recursos na manutenção dos seus objetivos institucionais", conforme a redação do inciso II, do art. 14 do Código

82 INSTITUTO PARA O DESENVOLVIMENTO DO INVESTIMENTO SOCIAL - IDIS. Fundos Patrimoniais Vinculados - Proposta de Projeto de Lei. São Paulo: IDIS. 2014.

${ }^{83}$ Op. cit. 
Tributário Nacional, impediria as OSC de manterem recursos em fundos patrimoniais.

Como este, muitos outros exemplos ilustram este tipo de situação que se repete com as OSC.

Pontue-se o que o pagamento de determinados direitos dos trabalhadores de OSC é visto pela fiscalização como "distribuição de benefícios ou vantagens", como é o caso, por exemplo, de programas de PLR - participação nos lucros e resultados das organizações.

Em processo administrativo de reconhecimento de uma OSC como Entidade como Promotora de Direitos Humanos, que tramitou na Secretaria da Justiça e Defesa da Cidadania do Estado de São Paulo no ano de 2011, a Administração estadual fundamentou o indeferimento do pedido pela alegada descaracterização do elemento "sem fins lucrativos" no fato da entidade receber contribuições de suas associadas. Veja-se o teor do parecer que fundamenta a decisão ${ }^{84}$.

De outra parte, observa-se que a Federação interessada prevê a existência de pagamento de contribuicões associativas por parte dos associados, sob pena de exclusão (art. 11 do Estatuto Social). $E$, com isso resta descaracterizada sua natureza de entidade sem fins lucrativos, o que, de acordo com a Resolução SF/SJDC n. 01/02, é elemento intrínseco ao conceito de entidades promotoras de direitos humanos. (Grifos nossos)

O recurso interposto contra a decisão foi negado. A instituição não quis discutir o tema no Poder Judiciário, pois o procedimento administrativo tem renovação anual pela própria Secretaria que deu a decisão, e the pareceu muito burocrático, custoso e até mesmo constrangedor dar continuidade ao processo.

A possibilidade de um agente público, em especial um fiscal da arrecadação tributária, classificar determinada despesa de uma OSC como "não justificada nos seu objetivo social" impõe um risco muito grande às OSC, que, em razão das isenções e imunidades tributárias a quem tem direito, são submetidas a viverem com verdadeiras espadas de Dâmocles ${ }^{85}$, permanentemente pendentes sobre suas

\footnotetext{
${ }^{84}$ Processo n‥00806/2011.

$85 \mathrm{O}$ mito de Dâmocles é usado para simbolizar o permanente sentimento de insegurança e de revés iminente, como preço a se pagar por um tratamento especial, diferenciado. Conta a história que Dâmocles era cortesão muito bajulador, que reputava o tirano Dionísio muito afortunado, em razão de
} 
cabeças. Não raro essas organizações são chamadas a comprovar, por reiteradas vezes, que "não aplicam seus recurso em desacordo com as suas finalidades sociais", que "não distribuem lucro", que "não remuneram acima de valores de mercado".

Nestas situações, a prática da fiscalização e do controle sobre as OSC evolui para uma verdadeira de inversão da presunção de inocência a que toda pessoa física e jurídica faz jus num Estado democrático de direito, na medida em que às OSC costuma ser imposto o ônus de provar que não descumpre a lei como prérequisito para gozo de direitos assegurados em Lei e na Constituição.

Por esta razão é que preservar os elementos de integridade das OSC é essencial para possibilitar o exercício da participação social e da "cidadania plena" ${ }^{86}$, expressão utilizada pela Professora Eunice Aparecida de Jesus Prudente, para quem a "cidadania plena para todos" integra o "direito de participar":

\begin{tabular}{l} 
A sociabilidade faz parte da essência do ser. A organização da vida em \\
sociedade que tem início pela participação política, constitui direito anterior \\
a essa mesma organização e suas normas. (...) Cabe às Constituicões, na \\
posicão hegemônica em relacão ao ordenamento iurídico, reconhecer \\
o direito à participação política, disciplinando seu exercício, no sentido de \\
atender essa vocação ontológica e perene: todos no governo do Estado \\
(sociedade política), responsável pela convivência. Ao direito posto cabe \\
aperfeicoar o exercício da cidadania, possibilitar sempre e e \\
intensamente a participacão de todos, nunca restringir ou ou \\
\hline obstacularizar." ${ }^{87}$ (Grifos nossos)
\end{tabular}

A mesma interpretação que ora equipara as OSC a empresas privadas, ora as iguala a entidades públicas. Como ao fazer a analogia é comum que o resultado seja a aplicação da regra menos vantajosa para as OSC, fica a suspeita de existência de uma espécie de preconceito institucional contra essas entidades (normalmente mais pobres e menos reconhecidas que as empresas e que o Poder

todo luxo, poder e autoridade de que dispunha. Um dia, Dionísio lhe propôs trocarem de lugar, com o que Dâmocles rapidamente consentiu. Logo na primeira noite, Dâmocles foi servido como um rei ao final do jantar notou que pendia sobre sua cabeça uma espada afiada, presa a um único fio de rabo de cavalo. Imediatamente Dâmocles perdeu o interesse pela vida de rei, da qual abriu mão, dizendo que não queria ser tão afortunado.

${ }^{86}$ PRUDENTE, Eunice Aparecida de Jesus. Direito à personalidade integral: cidadania plena. Tese (Doutorado em Direito) - Universidade de São Paulo. 1996, p. 97.

${ }^{87}$ Op. cit. p. 100. 
Público), acentuando a desigualdade econômica e a exclusão dessas organizações $^{88}$ e, especialmente, dos grupos que elas representam.

A desconsideração de importantes elementos da integridade das OSC (dimensão da liberdade) aumenta gradativamente quando analisamos situações em que está em jogo a atuação relativa às outras duas dimensões (de participação e de financiamento).

A seguir, escolhemos os temas da remuneração de dirigentes e do não retrocesso, para analisar de forma mais detida como este fenômeno ocorre na prática.

\subsubsection{Análise de Caso: A questão da Remuneração de Dirigentes}

Este é um caso muito revelador do nível de barreira que pode ser imposta por um dispositivo na legislação de aparente simplicidade, que teria efeitos apenas relativos ao âmbito interno das OSCs.

Antes de tudo é importante registrar que não há na legislação brasileira qualquer previsão que proíba trabalhadores que atuem como dirigentes de Organizações da Sociedade Civil (OSCs) de serem remunerados. Uma vedação neste sentido representaria a obrigatoriedade do trabalho voluntário, afrontando a liberdade individual, a garantia do salário e a liberdade de auto-organização das associações, previstas na Constituição Federal, nos arts. $5^{\circ}, 6^{\circ}$ e $7^{\circ}$, na sequência, transcritos:

Art. $5^{\circ}$ Todos são iguais perante a lei, sem distinção de qualquer natureza, garantindo-se aos brasileiros e aos estrangeiros residentes no País a inviolabilidade do direito à vida, à liberdade, à igualdade, à segurança e à propriedade, nos termos seguintes:

$[\ldots]$

\footnotetext{
${ }^{88}$ Para muitas instituições é difícil superar este tipo de barreira. A necessidade de especialistas para boa representação das OSC e o custo com assessoria jurídica especializada favorece a defesa das mais ricas. As Defensorias Públicas normalmente apoiam a constituição de associações, mas há dificuldade em manter a assessoria permanente. Há iniciativa que buscam melhorar esta realidade, com destaque párea a ABONG _ Associação Brasileira de Organizações Não Governamentais, que oferece informações para orientação jurídica na dimensão do fortalecimento institucional das OSC; e para o Instituto Pro Bono, que intermédia a oferta entre advogados voluntários e organizações que necessitam de serviços jurídicos.
} 
XIII - é livre o exercício de qualquer trabalho, ofício ou profissão, atendidas as qualificações profissionais que a lei estabelecer;

$[\ldots]$

XVIII - a criação de associações e, na forma da lei, a de cooperativas independem de autorização, sendo vedada a interferência estatal em seu funcionamento.

Art. 60 São direitos sociais a educação, a saúde, a alimentação, o trabalho, a moradia, o lazer, a segurança, a previdência social, a proteção à maternidade e à infância, a assistência aos desamparados, na forma desta Constituição.

Art. $7^{\circ}$ São direitos dos trabalhadores urbanos e rurais, além de outros que visem à melhoria de sua condição social:

$[\ldots]$

VII - garantia de salário, nunca inferior ao mínimo, para os que percebem remuneração variável. (Grifos nossos).

O que existe na legislação é o estabelecimento de condições e consequências para as organizações que optem por remunerar seus dirigentes, de modo que a OSC que os remunere deve observar as limitações legais existentes, sem as quais perderá isenções tributárias e, eventualmente, registros administrativos. Isso porque a remuneração de dirigentes impede a inscrição da OSC em determinados órgãos públicos, como, por exemplo, nos Conselhos Municipais de Assistência Social, e a obtenção de acreditações, como a Declaração de Utilidade Pública Federal.

Essas limitações à remuneração dos dirigentes das OSC têm origem numa ideia antiga de filantropia, normalmente vinculada a ações da Igreja católica ou de famílias abastadas, que se mobilizavam para "ajudar os mais pobres". A Lei n-91/1935, sancionada pelo Presidente Getúlio Vargas, trata do certificado de Utilidade Pública Federal para as OSC e estabelece como requisito a vedação que a entidade remunere dirigentes. Vejamos o texto da lei, que continua em vigor nos dias de hoje, a seguir, transcrito na ortografia original:

Art 1ㅇ As sociedades civis, as associações e as fundações constituidas no paiz com o fim exclusivo de servir desinteressadamente à collectividade podem ser declaradas de utilidade pública, provados os seguintes requisitos:

[...]

c) que os cargos de sua diretoria, conselhos fiscais, deliberativos ou consultivos não são remunerados. (Grifos nossos). 
Além da Lei de Utilidade Pública Federal, a Lei do Imposto de Renda (Lei ํo9.532, de 10 de dezembro de 1997) também vincula a isenção às entidades sem fins lucrativos que não remunerem seus dirigentes de OSCs. Os arts. 12 e 15 dessa lei estabelecem que as entidades sem fins lucrativos têm o direito de gozar das isenções ao Imposto Sobre a Renda (IR) e à Contribuição Social Sobre Lucro Líquido (CSSL) se, entre outros requisitos, não remunerarem, sob qualquer forma, seus dirigentes:

\begin{abstract}
Art. 12. Para efeito do disposto no art. 150, inciso VI, alínea "c", da Constituição, considera-se imune a instituição de educação ou de assistência social que preste os serviços para os quais houver sido instituída e os coloque à disposição da população em geral, em caráter complementar às atividades do Estado, sem fins lucrativos.

[...]

$\S 2^{\circ}$ Para o gozo da imunidade, as instituições a que se refere este artigo, estão obrigadas a atender aos seguintes requisitos:
\end{abstract}

a) não remunerar, por qualquer forma, seus dirigentes pelos serviços prestados;

$[\ldots]$.

Art. 15. Consideram-se isentas as instituições de caráter filantrópico, recreativo, cultural e científico e as associações civis que prestem os serviços para os quais houverem sido instituídas e os coloquem à disposição do grupo de pessoas a que se destinam, sem fins lucrativos [...]

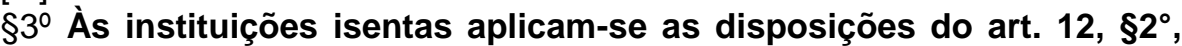
alíneas "a" a "e" e $\S 3^{\circ}$ e dos arts. 13 e 14. (Grifos nossos).

A crescente profissionalização das OSC resultou na revisão do ordenamento jurídico das entidades do chamado Terceiro Setor. Na ocasião em que foi proposta a Lei das Organizações da Sociedade Civil de Interesse Público - OSCIPs, o tema da remuneração de dirigentes ocupou papel central nos debates.

Em 23 de março de 1999, foi sancionada a Lei o 9.790 (Lei das OSCIPs), que exige que o Estatuto Social das entidades interessadas em se qualificar como OSCIP disponha sobre a remuneração de dirigentes.

Art. 4ํ Atendido o disposto no art. 3ํㅡ, exige-se ainda, para qualificarem-se como Organizações da Sociedade Civil de Interesse Público, que as pessoas jurídicas interessadas sejam regidas por estatutos cujas normas expressamente disponham sobre:

$[\ldots]$

$\mathrm{VI}$ - a possibilidade de se instituir remuneração para os dirigentes da entidade que atuem efetivamente na gestão executiva e para aqueles que a ela prestam serviços específicos, respeitados, em ambos os 
casos, os valores praticados pelo mercado, na região correspondente a sua área de atuação. (Grifos nossos).

A Lei das OSCIPs, ao prever a possibilidade dessas entidades remunerarem seus dirigentes determina as bases para o estabelecimento dos valores, mas não revoga a Lei 9.532/1997, fazendo com que, na prática, as OSCIP que decidam remunerar seus dirigentes, possam sofrer a consequência de perder as isenções do IR e da CSSL das quais trata a Lei 9.532/97.

Seguindo a linha de uma maior profissionalização das relações de trabalho nas OSCs, bem como de valorizar a atuação do Terceiro Setor, no ano de 2002, foi sancionada a Lei no 10.637 , que, em seu art. 34, autorizou as entidades qualificadas como OSCIP a remunerar seus dirigentes sem perder a imunidade ou a isenção da Lei no9.532/97. Mas a lei não parou por aí. Estabeleceu também que a relação de trabalho do dirigente seja formalizada com vínculo empregatício e que sua remuneração não ultrapasse ao teto do Poder Executivo Federal.

\begin{abstract}
Art. 34. A condição e a vedação estabelecidas, respectivamente, no art. $13, \S 2^{\circ}$, III, b, da Lei no 9.249 , de 26 de dezembro de 1995, e no art. 12, $\$ 2^{\circ}$, a, da Lei no 9.532 , de 10 de dezembro de 1997 , não alcançam a hipótese de remuneração de dirigente, em decorrência de vínculo empregatício, pelas Organizações da Sociedade Civil de Interesse Público (OSCIPs), qualificadas segundo as normas estabelecidas na Lei no 9.790, de 23 de março de 1999, e pelas Organizações Sociais (OS), qualificadas consoante os dispositivos da Lei no 9.637, de 15 de maio de 1998". (Grifos nossos).
\end{abstract}

Esta lei representou um importante avanço para a matéria, porém ficou adstrita somente às OSCIPs. Vale destacar que a imposição de que a relação de trabalho se dê com vínculo de emprego nem sempre contempla adequadamente a realidade. Não é incomum que dirigentes de OSC prestem serviços específicos, pontuais, nos projetos das organizações como é o caso, por exemplo, de dirigentes que participam como instrutores em capacitações esporádicas. Estes (e tantos outros casos) ficam de fora da regra da Lei 10.637/2002.

Apenas recentemente, no âmbito do Programa do Marco Regulatório das OSC, a Lei o 12.868 , de 16 de outubro de 2013, alterou também a Lei nำ.532/1997, acima citada, acrescentando os $\S \S^{\circ}, 5^{\circ}$ e $6^{\circ}$ à redação original do art. 12, para estabelecer condições que, uma vez observadas, garantem a 
manutenção da isenção ao IR e à CSLL da OSC, acrescentando os $\S \S^{\circ}, 5^{\circ}$ e $6^{\circ}$ ao art. 12, estabelecendo requisitos para remuneração de dirigentes das OSC em geral:

Art. 12. Para efeito do disposto no art. 150, inciso VI, alínea "c", da Constituição, considera-se imune a instituição de educação ou de assistência social que preste os serviços para os quais houver sido instituída e os coloque à disposição da população em geral, em caráter complementar às atividades do Estado, sem fins lucrativos.

[...]

$\S 2^{\circ}$ Para o gozo da imunidade, as instituições a que se refere este art. , estão obrigadas a atender aos seguintes requisitos:

a) não remunerar, por qualquer forma, seus dirigentes pelos serviços prestados;

[...].

§4ํ A exigência a que se refere a alínea "a" do §2ํㅡão impede: (Incluído pela Lei no12.868, de 2013)

I - a remuneração aos diretores não estatutários que tenham vínculo empregatício; e (Incluído pela Lei n⒓868, de 2013)

II - a remuneração aos dirigentes estatutários, desde que recebam remuneração inferior, em seu valor bruto, a $70 \%$ (setenta por cento) do limite estabelecido para a remuneração de servidores do Poder Executivo federal. (Incluído pela Lei $\mathrm{n} \div 12.868$, de 2013)

§5을 $\mathrm{A}$ remuneração dos dirigentes estatutários referidos no inciso II do \$4 ${ }^{\circ}$ deverá obedecer às seguintes condições: (Incluído pela Lei no12.868, de 2013)

I - nenhum dirigente remunerado poderá ser cônjuge ou parente até 3ำ(terceiro) grau, inclusive afim, de instituidores, sócios, diretores, conselheiros, benfeitores ou equivalentes da instituição de que trata o caput deste artigo; e (Incluído pela Lei n¹2.868, de 2013)

II - o total pago a título de remuneração para dirigentes, pelo exercício das atribuições estatutárias, deve ser inferior a 5 (cinco) vezes o valor correspondente ao limite individual estabelecido neste parágrafo (Incluído pela Lei $\mathrm{n} \times 12.868$, de 2013)

$\$ 6^{\circ}$ O disposto nos $\$ \$^{\circ}$ e $5^{\circ}$ não impede a remuneração da pessoa do dirigente estatutário ou diretor que, cumulativamente, tenha vínculo estatutário e empregatício, exceto se houver incompatibilidade de jornadas de trabalho. (Incluído pela Lei $\mathrm{n} \times 12.868$, de 2013). (Grifos nossos).

Como se vê, a lei autoriza que OSC isentas remunerem seus dirigentes desde que cumpram requisitos legais ligados à vedação de parentesco, tetos de valor e também ligados à forma de contratação. A Lei do CEBAS (Lei no12.101/2009), também, foi modificada pela Lei $\mathrm{n} \times 12.868 / 2013$, passando a estabelecer essas mesmas condições, com o acréscimo dos $\S \S 1^{\circ}, 2^{\circ}$ e $3^{\circ}$ ao art. 29.

É inegável que a Lei no $12.868 / 2013$ avançou ao reconhecer a possibilidade de remuneração dos dirigentes das OSC no Brasil. Todavia, também salta aos olhos a criação de novas limitações desnecessárias, com redação imprecisa e demasiadamente abrangente, limitando o exercício da liberdade de associação, 
como é o caso do texto que determina a proibição de que se remunerem dirigentes com parentesco "até $3^{\circ}$ (terceiro) grau, inclusive afim, de instituidores, sócios, diretores, conselheiros, benfeitores ou equivalentes da instituição".

Assim, conquanto os avanços na legislação existam, a nova redação reflete a ausência de coerência e organização administrativa da regulamentação das organizações da sociedade civil, formada por legislações esparsas e muitas vezes contraditórias.

\subsubsection{Não Retrocesso}

Quanto mais aumenta o nível de tensão entre as OSC e o Estado, mais forte é a desconsideração de importantes aspectos de elementos estruturantes das organizações enquanto sujeitos de direito.

Este tipo de tratamento mais favorável às instituições que cooperam com o interesse do Estado inibe a participação efetiva, afinal, as OSC que criarem menor nível de dificuldade para o Estado serão recompensadas, adequadamente "retribuídas", com uma interpretação mais favorável no tocante às suas situações.

Essa pode ser uma das explicações para uma curiosa constatação: a Lei Federal das OSs (Lei 9.637/98), que foi objeto de ADI proposta pelo PT e PDT, estabelece o Contrato de Gestão, que é um instrumento de parceria para instituições que gerenciam bens, serviços e equipamentos públicos. Desde 1998, a ADI tramita no STF e, apesar de toda a crítica com relação à "terceirização" ou "privatização" de serviços públicos que envolve, o modelo tem sido utilizado por governos, inclusive dos partidos que ingressaram com a medida.

Hoje, boa parte das restrições existentes na execução dos chamados convênios (e também nos termos de parceria das OSCIP), na prática administrativa e de controle, têm sido aceitas e permitidas nos Contratos de Gestão das OS.

Como é sabido, a historicidade dos direitos humanos e todo o esforço travado em cada momento histórico para conquistá-los, determina que estes caminhem sempre no sentido de ampliar a sua proteção, de reconhecer novos direitos. 
Esta é a proibição de retrocesso em matéria de direitos humanos, também, conhecido como "efeito cliquet" ${ }^{89}$.

Nesse sentido, vale destacar que as violações ao direto de não retrocesso podem se dar pela via comissiva ou omissiva, ou seja, quando os Estados adotam medidas de caráter administrativo ou legislativo que interferem no dia a dia das organizações e ferem direitos já conquistados, ou quando deixam de adotar as medidas necessárias à proteção dos direitos fundamentais das OSCs, da liberdade de associação e da garantia da participação.

A noção de direitos humanos faz nascer em cada indivíduo o direito subjetivo à satisfação de seus direitos fundamentais, bem como a obrigação do Estado de programar políticas públicas voltadas à sua universalização para toda a coletividade. O direito administrativo diretamente impactado pelos direitos fundamentais é marcado pela importância atribuída a determinados princípios, como os da boa administração, da organização, da impessoalidade, da moralidade, entre outros.

A privatização do direito público e a constitucionalização do direito privado também são fenômenos que corroboram a dificuldade da distinção entre o público e o privado e a tendência à diminuição dos limites entre estes domínios, valorizandose a concretização de direitos garantidos em que as esferas do público e do privado sejam complementares.

O grande desafio é, portanto, buscar este equilíbrio entre o público e o privado na atuação das OSCs, principalmente quando financiadas pelo Estado, pois existe uma tendência dos Estados de impor a essas organizações normas e condutas típicas de entes públicos, gerando interferência estatal no seu funcionamento, distorções e violação de direitos adquiridos.

Diante da liberdade de auto-organização das associações e da obrigação do Estado de respeitar e fomentar o direito ao desenvolvimento da sociedade civil, a incidência das normas de direito público sobre essas entidades deve ser sempre a mínima necessária para garantir a atividade de relevância pública, o bem público juridicamente tutelado, zelando, de igual forma, pela característica privada das

${ }^{89}$ Expressão em francês originária do alpinismo, que define um movimento que só permite que o alpinista continue adiante em sua trajetória. 
entidades e pelos princípios aplicáveis ao uso do recurso público e à boa administração.

Assim, falar em não retrocesso significa zelar para que a regulamentação da dimensão de financiamento público não irradie seus efeitos para além dessas relações, ameaçando as outras duas dimensões: não interferência e participação.

Registre-se que a vedação ao retrocesso impõe ao Estado o impedimento de abolir, restringir ou inviabilizar sua concretização por inércia ou omissão, conforme tem se posicionado o Supremo Tribunal Federal:

\begin{abstract}
- A PROIBIÇÃO DO RETROCESSO SOCIAL COMO OBSTÁCULO CONSTITUCIONAL À FRUSTRAÇÃO E AO INADIMPLEMENTO, PELO PODER PÚBLICO, DE DIREITOS PRESTACIONAIS. - O princípio da proibição do retrocesso impede, em tema de direitos fundamentais de caráter social, que sejam desconstituídas as conquistas já alcançadas pelo cidadão ou pela formação social em que ele vive. - A cláusula que veda o retrocesso em matéria de direitos a prestações positivas do Estado (como o direito à educação, o direito à saúde ou o direito à segurança pública, v.g.) traduz, no processo de efetivação desses direitos fundamentais individuais ou coletivos, obstáculo a que os níveis de concretização de tais prerrogativas, uma vez atingidos, venham a ser ulteriormente reduzidos ou suprimidos pelo Estado. Doutrina. Em consequência desse princípio, o Estado, após haver reconhecido os direitos prestacionais, assume o dever não só de torná-los efetivos, mas, também, se obriga, sob pena de transgressão ao texto constitucional, a preservá-los, abstendo-se de frustrar - mediante supressão total ou parcial - os direitos sociais já concretizados. (ARE-639337- Relator(a): Min. CELSO DE MELLO).
\end{abstract}

Para atender à dimensão do respeito à não interferência estatal no funcionamento das OSCS, o Estado deve se abster de criar barreiras para a criação, funcionamento e financiamento das organizações. Com relação à dimensão da participação, os canais e mecanismos de participação devem funcionar não apenas no aspecto formal, mas também no aspecto material, buscando valorizar a participação. Já a regulamentação das ações de contratualização deve propiciar a difusão das boas iniciativas das organizações para os problemas da sociedade, bem como a sua eventual participação na execução direta de determinadas políticas públicas.

É fato que essa última dimensão, conforme se demonstrou, é a mais recentemente adquirida pelas organizações da sociedade civil e existem muitos riscos ligados a esta atuação como braço do Estado, diante da possibilidade de cooptação pelos governos que financiam sua existência. 
Nos últimos tempos, houve diferentes episódios de denúncias envolvendo desvio de verbas públicas por organizações da sociedade civil, por conseguinte, reacendendo a discussão sobre a regulamentação das relações de financiamento público envolvendo as OSC.

Relatórios das sub-regiões da América Latina (Região Andina, América Central e Cone Sul) elaborados no já referenciado projeto da Mesa de Articulação Latino Americana, descrevem práticas dos Estados de vincular a participação de OSC em determinadas áreas, ao seu financiamento. Neste caso, o retrocesso com relação ao direito de participação caminha no sentido da cooptação, ou seja, de proibir que organizações que não sejam prestadoras de serviços na execução da política, participem das instâncias de controle social.

Iniciativas como essas geram uma lógica antidemocrática, com efeitos opostos à noção de participação, pois reforçam uma ideia de especialização e segmentação das OSCs. Este tipo de pensamento pode afastar algumas OSC da operação e outras da crítica, como se fossem estas atividades excludentes entre si, comprometendo assim o controle social mais abrangente e independente.

A regulamentação das Organizações da Sociedade Civil não deve retroceder. A Liberdade de Associação deve assegurar o respeito às suas três dimensões, que aprofundam, especificam e evoluem no reconhecimento do papel dessas organizações numa sociedade democrática.

O desafio do não retrocesso se coloca justamente ao regulamentar as relações de financiamento e de participação em cooperação com o Estado. Diante da necessidade de que os Estados estabeleçam critérios e processos democráticos de escolha das OSC para participar e receber financiamento público, surge o risco de que estabeleçam requisitos necessários que representem uma involução com relação à dimensão anterior, ou seja, que criem verdadeira interferência estatal no funcionamento das entidades, assim, inviabilizando sua existência autônoma.

Parece-nos ser esta a hipótese dos casos que, ao regulamentar as condições de acesso a financiamento público, vedam a participação de Organizações da Sociedade Civil, para tanto, utilizando-se de critérios que comprometem desnecessariamente o seu direito à participação. 
Não é incomum encontrar situações em que a participação pelas OSC em determinados espaços é vista como condição de inabilitação para recebimento de financiamento público.

Prova deste fenômeno é a determinação, pelos Conselhos Municipais de Assistência Social, Brasil afora, de que a participação paritária nesses Conselhos por representes de organizações da sociedade civil deva ficar vinculada à demonstração, pela entidade, de capacidade operacional para execução da política do Sistema Único da Assistência Social - SUAS.

Há Conselhos de Políticas Públicas e recomendação da Corte de Contas que determinam que os Ministérios "abstenham-se de celebrar convênios com entidades vinculadas a membros de conselhos, em atenção aos princípios da moralidade e da impessoalidade" (Acórdão TCU n810/2010) (Grifos nossos).

Em 23 de outubro de 2005, foi realizado um referendo por meio do qual todos os cidadãos brasileiros responderam à pergunta: "o comércio de armas de fogo e munição deve ser proibido no Brasil?". O resultado do referendo foi "não": a maioria dos brasileiros votou pela manutenção da legalidade da venda de armas de fogo no país. O processo de votação foi conduzido pelo Tribunal Superior Eleitoral, que editou a Resolução TSE n²2.041/2005, que vedava a participação de "entidades sem fins lucrativos que receba recursos do exterior" como colaboradoras dos trabalhos das Frentes Parlamentares responsáveis pela condução do processo de discussão pública do referendo. A medida proibiu que importantes OSCs, inclusive muitas que lutaram pela realização do referendo, participassem do processo de campanha pública para a votação. ${ }^{90}$ Este é um exemplo típico em que uma norma de financiamento de OSC influencia diretamente a participação de OSCs.

Como já se demonstrou, nos últimos anos, a Administração aumentou significativamente a sua regulamentação sobre as OSC, tornando-a ainda mais formalista e burocrática. Na forma inadequada como esta legislação hoje está estabelecida, o alcance das dimensões da liberdade e da participação pelas normas

\footnotetext{
${ }^{90} \mathrm{Na}$ época, analisamos o assunto em artigo publicado em coautoria: STORTO, Paula; HIRAO, Denise . A legalidade da participação da sociedade civil organizada no Referendo. Revista do Terceiro Setor da RITS Rede de Integração do Terceiro Setor, Rio de Janeiro, 15 set. 2005. Disponível em: $<\mathrm{http}: / /$ www.migalhas.com.br/dePeso/16,Ml16599,71043A+legalidade+da+participacao+da+sociedade+civil+organizada+no>. Acesso em: 23 nov. 2014.
} 
editadas para regulamentar as relações de contratualização sugerem a existência de ameaça às duas primeiras dimensões do direito de liberdade de associação.

Este retrocesso pode criar ameaças ao seu regular funcionamento e significar uma ameaça à cidadania plena, na medida em que a redução das desigualdades sociais pressupõe uma educação para o independente exercício da cidadania, processo para o qual as organizações da sociedade civil se apresentam como agentes privilegiados para desempenhar.

\subsection{RELAÇÕES DE PARCERIA COM O ESTADO}

\subsubsection{Regime Jurídico Aplicável às Relações de Parceria}

Relações de parceria englobam todo tipo de instrumento jurídico de natureza contratual para desempenho de atividade de relevância pública, que imponha direitos e obrigações entre organizações da sociedade civil e o Estado. Abarcam, assim, os convênios, acordos, contratos administrativos e outros instrumentos jurídicos de cooperação entre o Estado e as organizações da sociedade civil, como o Contrato de Gestão e Termo de Parceira, das Leis 9.637/98 (Lei das Organizações Sociais) e 9.790/99 (Lei das OSCIPs), respectivamente.

A expressão "relevância pública", é utilizada pelo Anteprojeto de Lei Orgânica da Administração Pública, elaborado por Comissão de Juristas instituída pelo Ministério do Planejamento, Orçamento e Gestão, por meio da Portaria MP n 426 , de 06 de dezembro de 2007, para propor uma nova estrutura orgânica para o funcionamento da Administração Pública Federal e das suas relações com entes de colaboração.

O texto do parágrafo único, do art. 74 do Anteprojeto de Lei Orgânica da Administração Pública, ao tratar das atividades de relevância pública assim se estabelece:

$[\ldots]$

Parágrafo único. Para fins deste artigo, são de relevância pública as atividades, ações e programas relativos especialmente aos seguintes campos:

a) assistência social;

b) cultura, proteção e conservação do patrimônio histórico e artístico; 
c) prestação de serviços de saúde, de educação e de outros serviços sociais diretamente à população, em caráter complementar ou suplementar aos serviços estatais, de forma inteiramente gratuita ou predominantemente gratuita;

d) incentivo ao voluntariado;

e) segurança alimentar e nutricional;

f) incentivo à prática de esportes;

g) desenvolvimento econômico e social e combate à pobreza;

h) promoção da ética, da paz, da cidadania, dos direitos humanos, da democracia e de outros valores universais;

i) preservação e conservação do meio ambiente e promoção do desenvolvimento sustentável;

j) experimentação, não lucrativa, de novos modelos socioprodutivos e de sistemas alternativos de produção, comércio, emprego e crédito;

k) promoção de direitos e assessoria jurídica gratuita; ou

l) estudos e pesquisas, desenvolvimento de tecnologias alternativas, produção e divulgação de informações e conhecimentos técnicos e científicos que digam respeito às atividades e finalidades mencionadas neste artigo.

O termo aparece também na parte introdutória do voto do Ministro Ayres Britto em sessão de julgamento da Ação Direta de Inconstitucionalidade 1923, contra a Lei ำ9.637/98 (Lei das OS) ocasião em que o Ministro manifestou-se sobre a constitucionalidade da prestação de serviços de utilidade pública por entidades do Terceiro Setor em geral, para, após, passar a analisar a questão da Lei das OS, propriamente dita. Veja-se o trecho a seguir transcrito do voto:

Já no que toca às atividades de senhorio misto, serão elas de natureza pública, se prestadas pelo próprio Estado, ou em parceria com o setor privado. E se desempenhadas exclusivamente pelo setor privado, sua definição é como atividades ou serviços de relevância pública (inciso $\Perp$ do art. 129 e art. 197, ambos da CF).

Eis que "atividades de relevância pública" são aquelas passíveis de colaboração entre entidades do Terceiro Setor e o Estado (seja por meio de sua atividade de fomento ou da delegação), incluindo os serviços de utilidade pública prestados pelas entidades do Terceiro Setor, com o objetivo de satisfazer concretamente às necessidades coletivas, de forma autônoma e independentemente de qualquer participação do Estado, bem como os mesmos serviços quando prestados com o financiamento do Estado, consubstanciando-se, neste caso, serviços públicos sociais.

Note-se que as atividades de relevância pública incluem serviços e outras ações passíveis de colaboração, a exemplo daqueles previstos na lista 
exemplificativa do parágrafo único, do art. 74, do Anteprojeto de Lei Orgânica da Administração Pública, cujo conteúdo, neste aspecto, muito se assemelha aos serviços relacionados pelo Min. Ayres Britto em seu voto Ação Direta de Inconstitucionalidade 1923.

Ou seja, são diversas atividades próprias das entidades sem fins lucrativos, como também aquelas que podem por elas ser desempenhadas no âmbito de políticas públicas específicas, com a celebração de instrumento de cooperação, seja em regime de delegação ou por meio da atividade administrativa de fomento, com repasse de recursos públicos pelo Estado.

A atual concepção de serviço público tem a sua origem ligada ao julgamento do famoso caso "Blanco" pelo Tribunal de Conflitos francês, em 8 de fevereiro de 1873, que, ao analisar a responsabilidade de empresa pública francesa sobre o atropelamento da menina Agnès Blanco, utilizou-se do fato do serviço em questão ser prestado pelo Estado, advinha a responsabilidade do Estado, determinando, portanto, a jurisdição da Justiça Administrativa sobre o caso.

No início do século $X X$, a Escola do Serviço Público francesa, liderada por Léon Deguit e Gastón Jèze, desenvolveu estudos na área, caracterizando-se em torno das seguintes duas grandes ideias centrais, como bem sintetiza a professora Maria Sylvia Zanella di Petro ${ }^{91}$ :

(a) trata-se de atividade ou organização assumida por uma coletividade pública (a chamada publicatio); e (b) o seu objetivo é o de satisfazer a uma necessidade de interesse geral. A estes dois elementos tem-se que acrescentar um terceiro, que era a submissão dos serviços públicos a regime jurídico derrogatório do direito comum.

Ainda segundo a ilustre professora, assim foi que, em suas origens, os autores adotavam três critérios para a definição do serviço público: (I) subjetivo: serviço prestado pelo Estado; (II) material: atividade que visa a satisfação de necessidades coletivas; e (III) formal: exercido sob regime derrogatório e exorbitante do direito comum.

${ }^{91}$ DI PIETRO, Maria Sylvia Zanella. Direito Administrativo. 25. ed. São Paulo: Atlas, 2012, p. 101. 
Com o Estado liberal e a consequente delegação pelo Estado de parcela de suas atividades, a pessoas jurídicas de direito privado, tanto da Administração Indireta, Entidades Paraestatais, Organizações do Terceiro Setor e Empresas Privadas, é fato, que foram afetados dois importantes elementos da definição adotada, quais sejam: o elemento subjetivo (pois particulares passaram a prestar serviços públicos) e o elemento formal (já que nem todo serviço público estaria mais submetido ao regime jurídico exclusivamente público).

Hodiernamente, a noção de serviço público permanece bastante vinculada à fonte da Escola do Serviço Público, com especial influência sobre o pensamento daqueles doutrinadores que assumem um conceito amplo de serviço público, no qual este envolveria toda atividade desempenhada pelo Estado, incluindo legislação, jurisdição e execução. Há ainda aqueles doutrinadores que admitem um conceito estrito de serviço público, que abarcaria apenas as ações de execução, ou, ainda, parte dessas ações.

O conceito de serviço público nos oferece elementos jurídicos relacionados à análise de sua prestação por organizações do Terceiro Setor, sendo de extrema valia o conceito de serviço público proposto por Maria Sylvia Zanella di Pietro, para quem, "serviço público é toda atividade material que a lei atribui ao Estado para que a exerça diretamente ou por meio de seus delegados, com o objetivo de satisfazer concretamente às necessidades coletivas, sob regime jurídico total ou parcialmente público". ${ }^{92}$

A força desta ideia reside no fato de que, ao circunscrever o aspecto material à escolha da lei, assim, possibilita a sua permanente atualidade do conceito no tempo e no espaço, bem como sua adaptação às diferentes realidades da dimensão formal, e comporta na análise do caso concreto, uma adequada interpretação e derrogação das normas de direito privado pelas normas do direto público na interação entre pessoas jurídicas de direito privado e o Estado na prestação de serviços públicos.

Entre as diversas classificações que o conceito de serviço público pode suportar, interessa-nos aquela que abarca a dimensão do objeto dos serviços entre

${ }^{92}$ DI PIETRO, Maria Sylvia Zanella. Direito Administrativo. 25. ed. São Paulo: Atlas, 2012. 
(i) administrativos: que atendem às necessidades próprias da Administração; (ii) comerciais ou industriais: que atendem a necessidades coletivas de ordem econômica, que apenas podem ser prestados pelo Estado em caráter suplementar à iniciativa privada; e (iii) sociais: assim entendidos aqueles que atendem a necessidades coletivas em que a atuação do Estado é essencial, mas que convivem com a iniciativa privada, como é o caso dos serviços de saúde, educação, meio ambiente, cultura, previdências e outros destinados a atender os direitos sociais, fundamentais do cidadão, previstos no art. 6을 da Constituição Federal.

Especificamente com relação à prestação dos serviços públicos que têm por objeto a realização de serviços sociais, cumpre destacar que estes comportam as formas de gestão tradicionais, já consolidadas na literatura administrativista (administração direta, indireta ou sob regime de concessão, permissão ou autorização, conforme teor dos arts. 21 e 175 da Constituição), bem como os instrumentos de colaboração com entidades do Terceiro Setor, incluindo o contrato de gestão com as organizações sociais (da Lei. 9.637, de 15 de maio de 1998), além de outras espécies, assim considerados os Convênios, Termos de Parceria (da Lei 9.790, de 9 de março de 1999) e os recém-instituídos Termos de Fomento e Termo de Colaboração (Lei 13.019/2014).

\subsubsection{Controle e as Prestações de Contas das Relações de Parceria}

Muito se discute sobre o controle dos atos administrativos, seus limites, finalidade e competência dos órgãos de controle interno e externo e também a institucionalidade do controle social. Em tempos de Lei de Acesso à Informação e Lei Anticorrupção, a discussão acerca dos limites do controle tende a se ampliar, a partir da constatação da necessidade de identificar os caminhos da corrupção e de criar mecanismos institucionais para o seu combate.

Como bem aponta o professor Floriano de Azevedo Marques $\mathrm{Neto}^{93}$, a multiplicidade dos controles pode levar à insegurança, devendo a atividade

${ }^{93}$ MARQUES NETO, Floriano de Azevedo. Os grandes Desafios do Controle da Administração pública. In: MODESTO, Paulo (Coord.). Nova Organização Administrativa Brasileira. 2. ed.Belo Horizonte: Fórum, 2010. 
administrativa de controle ser balizada pela responsividade do Estado nessa atuação, ou seja, a atuação do agente público deve ser guiada pelo equilíbrio entre o poder a ela conferido e o compromisso com as consequências de seu uso.

Aspecto curioso do controle exercido pelo Tribunal da União, que tem sido objeto de análise e crítica, é o controle preventivo que realiza, manifestando-se sobre a adequação de editais que serão lançados, ou, por vezes, determinando a paralisação de obras de infraestrutura, imiscuindo-se, em alguma medida, no processo de condução da atividade administrativa, a cargo do poder Executivo.

É importante reconhecer a importância do controle e da atuação preventiva das Cortes de Contas no acompanhamento ordinário das contas públicas e no combate à corrupção, mas deve ser vista com cautela a dimensão normativa que a atuação preventiva tem tomado, diante dos riscos a ela inerentes.

Caso interessante em que esse fenômeno aconteceu, com efeitos comprovadamente nocivos, é o do controle referente aos recursos públicos repassados às OSC, por meio de instrumentos de colaboração (convênios, termos de parcerias, contratos de repasse, entre outros), como demonstrado a seguir.

Em artigo que recentemente publicamos na obra coletiva "Direito Privado Administrativo"94, analisamos a incidência do Direito Público nas organizações da sociedade civil e, nesse contexto, identifica-se a recomendação formulada pelo Tribunal de Contas da União no Acórdão 1070/2003, que "determinou" a alteração do art. 27 da IN 01/97 (que regulamentava à época as relações de convênio entre OSC e a União), obrigando as entidades privadas a realizar licitação nos termos da Lei 8.666/93, quando da utilização dos recursos repassados por convênios.

O Voto do Ministro Relator no processo, ao contrário do que dispõe a Constituição Federal e a própria Lei 8.666/93, entendeu sua integral aplicação a entidades privadas que administram recursos públicos e determina a alteração da referida IN 01/97:

[...] Note-se que a entidade privada não está obrigada a firmar convênio com a administracão pública, mas, ao assinar, deve ter a certeza que

${ }^{94}$ STORTO, Paula Raccanello. A incidência do Direito Público sobre as Organizações da Sociedade Civil sem Fins Lucrativos. In: DI PIETRO, Maria Sylvia Zanella; RIBEIRO, Carlos Vinícius Alves (Coords.). Direito Privado Administrativo. São Paulo: Atlas, 2013. 
está administrando recursos públicos em sentido estrito e, isto é, verbas incluídas em lei orçamentária, dessa forma, deve observar rigorosamente, como todo administrador público, os princípios que informam a gestão da coisa pública, em especial o da legalidade, sob o ponto de vista formal e material. Não pode, por isso mesmo, dar destinação diversa aos recursos, daquela fixada na lei orçamentária, sob pena de ser condenado à devolução das importâncias recebidas por desvio de finalidade; não pode, ademais, deixar de prestar contas dos recursos recebidos, por expressa determinação constitucional; como também não pode descumprir a Lei no8.666/93. (Grifos nossos).

Esse acórdão, emitido logo após a instauração da primeira "CPI das ONGs", inaugura a fase de controle na produção legislativa da matéria e teve forte impacto no cenário de insegurança jurídica que se estabeleceu nas relações de parceria entre organizações da sociedade civil e o Estado, gerando prejuízos e colocando sob suspeita generalizada todas as OSC, inclusive as mais sérias e comprometidas.

Como era de se esperar, a urgência moralizadora não permitiu o adequado tratamento jurídico da matéria sob a perspectiva de direito privado e novamente se impôs a tendência de equiparar as OSC a entes públicos, em mais uma manifestação do já mencionado fenômeno da "maldição do regime único"

\begin{abstract}
E nem se diga que existem já na legislação aberturas para regimes legais diferençados, como as concessões de serviços públicos (Lei no 8.987/1995), os contratos de gestão com organizações sociais (Lei o 9.637/1998) ou as parcerias público-privadas (Lei o 11.079/2004). Tal refutação não calha, seja porque tais leis não contemplam um regime específico completo para esses contratos, contendo lacunas; seja porque a doutrina sempre procurará interpretar as disposições específicas para esses contratos a partir do regime jurídico legal, como se a Lei oㅡ 8.666/1993 tivesse uma prevalência (como regime geral dos contratos administrativos) ou, então, como se ela servisse de pauta hermenêutica para interpretar o regime especial. $^{96}$
\end{abstract}

Aí existe uma relação de evidente risco à autonomia e independência das OSCs, que encontrou, no controle externo, pelas Cortes de Contas, terreno fértil para a sua proliferação. Restringir a autonomia e a independência das OSC, afetando sua característica essencial de autoadministração, pode significar a criação de barreiras para as iniciativas de controle social e de participação realizadas por essas entidades, representando, assim, ameaça ao pleno desenvolvimento da cidadania.

${ }^{95}$ MARQUES NETO, Floriano Peixoto de Azevedo . Do Contrato Administrativo à Administração Contratual. Revista do Advogado, v. 107, p. 74-82, 2009. P. 77.

${ }^{96}$ Op. cit. p.78 
A atuação normativa do Tribunal de Contas da União tem incidido diretamente sobre as organizações da sociedade civil que recebem financiamento público, alcançando, pela via do controle preventivo, a atuação de muitas dessas entidades, com claro risco ao desenvolvimento das organizações, que podem ficar sujeitas ao crivo do fiscalizador do momento, ao determinar critérios e condições de participação às instâncias consultivas das políticas públicas do nosso país. 


\section{A LEI 13.019/2014 E A LIBERDADE DE ASSOCIAÇÃO DAS OSC}

\subsection{POLÍTICA NACIONAL DE FOMENTO E COLABORAÇÃO}

A Lei n¹3.019/2014, de 21 de julho de 2014, trata das relações jurídicas de cooperação entre OSC e o Poder Público. Referida norma reconhece como princípios a participação social como direito do cidadão; a solidariedade, a cooperação e o respeito à diversidade para a construção de valores; a promoção do desenvolvimento local, regional e nacional, inclusivo e sustentável; a valorização da diversidade cultural e da educação para a cidadania ativa; e a valorização dos direitos dos povos indígenas e das comunidades tradicionais.

Seu texto traz muitos avanços na regulamentação das parcerias entre OSC e a Administração Pública, como a substituição da figura dos antigos "convênios" pelos recém-criados "termo de colaboração" e "termo de fomento"; a previsão de Chamamento Público para seleção das organizações parceiras; a admissão do pagamento de despesas indiretas e de pessoal próprio com recursos públicos repassados; além de outras medidas importantes para o desenvolvimento institucional das OSC e o incremento da segurança jurídica na execução das parcerias.

Apesar destes avanços, a norma apresenta dispositivos que reforçam uma lógica excessivamente formalista e que dificultam a preservação das garantias constitucionais ligadas à liberdade de associação e de auto-organização das associações. A sua implementação demandará regulamentação adequada e capaz de equilibrar a necessidade de controle sobre os recursos públicos repassados e a garantia à liberdade e independência das OSCs.

A seguir, estão destacadas as principais características mencionadas nessa lei, que deve entrar em vigor em 27 de julho de 2015, se for aprovada a MP 658, de 29 de outubro de 2014, na forma apresentada pelo Executivo. Será uma lei geral, de abrangência nacional, aplicável às parcerias celebradas entre OSC e "União, Estados, Distrito Federal, Municípios e respectivas autarquias, fundações, empresas públicas e sociedades de economia mista prestadoras de serviço público, e suas subsidiárias", conforme enuncia 0 art. $1^{\circ}$. 
Esta característica proporcionará maior uniformização das normas incidentes sobre as parcerias, contribuindo assim para a estabilidade de que essas relações precisam, fortalecendo a participação da sociedade civil na coisa pública e o financiamento público dessas atividades. No entanto nem todas as normas da lei têm caráter geral, como é o caso, por exemplo, da disposição do $§ 2^{\circ}$ do art. 46: "A inadimplência da organização da sociedade civil em relação aos encargos trabalhistas não transfere à União a responsabilidade por seu pagamento", cujo alcance é evidentemente limitado à União.

Outro importante aspecto é que os "convênios" não mais serão aplicáveis às relações jurídicas entre Estado e OSCs, ficando restritos apenas às parcerias entre entes e estatais, nos termos do art. 84 da mesma lei:

Art. 84. Salvo nos casos expressamente previstos, não se aplica às relações de fomento e de colaboração regidas por esta Lei o disposto na Lei $\underline{n^{0}}$ 8.666, de 21 de junho de 1993, e na legislação referente a convênios, que ficarão restritos a parcerias firmadas entre os entes federados.

A utilização da legislação de convênios é causa de parte dos principais problemas que hoje as organizações vivem na relação com o Estado. O uso dos convênios contribuiu de forma expressiva para o atual ambiente de insegurança jurídica, com a imposição de normas de direito público para organizações da sociedade civil, regidas precipuamente pelo direito privado, gerando analogias indevidas. Este aspecto também foi apontado no estudo do NEATS-PUC/SP sobre a Modernização do Sistema de Convênios como um dos fatores que dificultam o desenvolvimento das OSC e recomendou a substituição dos convênios por outro instrumento jurídico específico para as relações de parceria com OSCs. ${ }^{97}$

Sublinhe-se que a lei inspirou-se no Anteprojeto da Lei Geral da Administração Pública proposto pela Comissão de Juristas ${ }^{98}$, formada por professores e profissionais renomados, constituída pela Portaria no-426, de 6 de dezembro de 2007, do Ministério do Planejamento, Orçamento e Gestão, que traz um regramento geral capaz de abarcar convênios, ajustes e Termo de Parceria

\footnotetext{
${ }^{97}$ Op. cit., p. 55

98 Para saber mais, ver MODESTO, Paulo (Coord.). Nova Organização Administrativa Brasileira. 2. ed. Belo Horizonte: Fórum, 2010.
} 
como espécies do Contrato Público de Colaboração, gênero apto a albergar as relações de contratualização. Essa proposta mostra-se alinhada à necessidade de elaboração normativa para os vínculos de contratualização entre Estado e organizações da sociedade civil, com caráter de norma geral, de âmbito nacional, portanto. Referido Anteprojeto inspirou as recentes propostas para o Marco Regulatório das Organizações da Sociedade Civil, priorizando a necessidade de planejamento anterior da política pública e processo de chamamento público para a seleção da entidade, sem, todavia, impor às relações de cooperação a rigidez e complexidade do processo de seleção de empresas para celebração de contratos administrativos disciplinadas na Lei de Licitações.

A Lei nº13.019/2014 reconhece a importância da atividade autônoma das OSC em prol do interesse público e a legitimidade de seu financiamento público. Os arts. $5^{\circ}$ e $6^{\circ}$ da lei estabelecem, respectivamente, os princípios fundamentais aplicáveis às parcerias e às diretrizes do regime jurídico de fomento e colaboração, entre os quais, destacam-se o protagonismo, a independência e a participação das OSC nos seguintes termos:

Art. 50 $\mathrm{O}$ regime jurídico de que trata esta Lei tem como fundamentos a gestão pública democrática, a participação social, o fortalecimento da sociedade civil e a transparência na aplicação dos recursos públicos, devendo obedecer aos princípios de legalidade, legitimidade, impessoalidade, moralidade, publicidade, economicidade, eficiência e eficácia, além dos demais princípios constitucionais aplicáveis e dos relacionados a seguir:

I - o reconhecimento da participação social como direito do cidadão; II - a solidariedade, a cooperação e o respeito à diversidade para a construção de valores de cidadania e de inclusão social e produtiva; III - a promoção do desenvolvimento local, regional e nacional, inclusivo e sustentável;

IV - o direito à informação, à transparência e ao controle social das ações públicas;

$\mathrm{V}$ - a integração e a transversalidade dos procedimentos, mecanismos e instâncias de participação social;

VI - a valorização da diversidade cultural e da educação para a cidadania ativa;

VII - a promoção e a defesa dos direitos humanos;

VIII - a preservação, a conservação e a proteção dos recursos hídricos e do meio ambiente;

IX - a valorização dos direitos dos povos indígenas e das comunidades tradicionais;

$X$ - a preservação e valorização do Patrimônio Cultural Brasileiro, em suas dimensões material e imaterial. (grifos nossos)

$[\ldots]$ 
Art. 6 São diretrizes fundamentais do regime jurídico de fomento ou de colaboração:

I - a promoção, o fortalecimento institucional, a capacitação e o incentivo à organização da sociedade civil para a cooperação com o Poder Público;

II - a priorização do controle de resultados;

III - o incentivo ao uso de recursos atualizados de tecnologias de informação e comunicação;

IV - o fortalecimento das ações de cooperação institucional entre os entes federados nas relações com as organizações da sociedade civil;

$\mathrm{V}$ - o estabelecimento de mecanismos que ampliem a gestão de informação, transparência e publicidade;

VI - a ação integrada, complementar e descentralizada (de recursos e ações) entre os Entes da Federação, evitando sobreposição de iniciativas e fragmentação de recursos;

VII - a sensibilização, a capacitação, o aprofundamento e o aperfeiçoamento do trabalho de gestores públicos, na implementação de atividades e projetos de interesse público e relevância social com organizações da sociedade civil;

VIII - a adoção de práticas de gestão administrativa necessárias e suficientes para coibir a obtenção, individual ou coletiva, de benefícios ou vantagens indevidas, em decorrência da participação no respectivo processo decisório ou ocupação de posições estratégicas;

IX - a promoção de soluções derivadas da aplicação de conhecimentos, da ciência e tecnologia e da inovação para atender necessidades e demandas de maior qualidade de vida da população em situação de desigualdade social. (grifos nossos)

Esses dispositivos, que tratam das normas gerais dos termos de colaboração ou de fomento, são orientadores de toda a interpretação da lei, prevalecendo sobre outros dispositivos cujos conteúdos possam confrontá-los. A eles vinculam-se todos os entes públicos na aplicação da Lei nำ13.019/2014, que devem atribuir maior relevo e importância jurídica aos princípios e diretrizes quando aplicarem a lei ao caso concreto.

O instrumento "termo de fomento" se diferencia do "termo de colaboração" em razão do reconhecimento da iniciativa da ação de interesse público ser proposta pela organização da sociedade civil, enquanto, no termo de colaboração, a iniciativa é proposta pela administração pública. A lei também inovou nessa matéria ao criar o "Procedimento de Manifestação de Interesse Social", a exemplo dos procedimentos que já existem no âmbito das concessões realizadas por meio de parcerias públicoprivadas - PPP, permitindo que as organizações da sociedade civil, movimentos sociais e até mesmo cidadãos apresentem propostas de chamamento público para a celebração de parceria, conforme a redação dos arts. 18 a 21 . A novidade demonstra o reconhecimento de que o repasse de recursos pode visar tanto à 
colaboração das OSC com políticas públicas para a atividade autônoma das organizações voltadas para o interesse público.

A Lei $\mathrm{n}$-13.019/2014 estabelece que os trabalhadores de OSC que atuem em projetos de cooperação com o Estado podem ser remunerados com os recursos disponibilizados para a execução do respectivo plano de trabalho.

Esta é uma das principais conquistas alcançadas com a nova lei, que supera o equivocado entendimento no sentido de que os recursos repassados por entes públicos não poderiam ser aplicados no pagamento de pessoal da organização. A redação do art. 46, inciso I, reconhece a autorização para pagamento, com recursos vinculados à parceria, de despesas trabalhistas, incluindo verbas rescisórias:

Art. 46. Poderão ser pagas com recursos vinculados à parceria, desde que aprovadas no plano de trabalho, as despesas com:

I - remuneração da equipe dimensionada no plano de trabalho, inclusive de pessoal próprio da organização da sociedade civil, durante a vigência da parceria, podendo contemplar as despesas com pagamentos de impostos, contribuições sociais, fundo de garantia por tempo de serviço, férias, décimo terceiro, salário proporcionais, verbas rescisórias e demais encargos sociais, desde que tais valores:

a) correspondam às atividades previstas para a consecução do objeto e à qualificação técnica necessária para a execução da função a ser desempenhada;

b) sejam compatíveis com o valor de mercado da região onde atua e não superior ao teto do Poder Executivo;

c) sejam proporcionais ao tempo de trabalho efetiva e exclusivamente dedicado à parceria celebrada; [...].

Nesse aspecto, a lei atendeu a reivindicação histórica das OSC e dos trabalhadores do segmento, assim, contribuindo para superar a situação de precarização das relações de trabalho nas OSC que se propõem a atuar em conjunto com o Estado. Cabe pontuar que a Lei no 13.019/2014 não trata da questão da remuneração de dirigentes no âmbito das parcerias, ficando a interpretação da matéria vinculada aos elementos do caso concreto, no qual prevalecerão as regras de cada instrumento contratual celebrado, incluindo a avaliação do que foi previsto no plano de trabalho pactuado entre a OSC e o ente público.

A Lei $\mathrm{n}$-13.019/2014 estabeleceu ainda a obrigatoriedade de ampla publicidade para o procedimento prévio à celebração das parcerias, por meio da realização do chamamento público, que deverá adotar procedimentos claros, 
objetivos e simplificados na seleção das OSCs, conforme redação do art. 23 e seguintes.

Para tanto, exige que a OSC tenha três anos de existência, além de experiência na área e capacidade técnica e operacional, como requisitos para participar de chamamento público voltado à celebração da parceria, nos termos do inciso VII, do $\S 1^{\circ}$, do art. 24.

A participação de pequenos projetos de organizações populares pode ser abarcada na criação do mecanismo inovador de permitir "a atuação em rede para a execução de iniciativas agregadoras de pequenos projetos por duas ou mais organizações da sociedade civil" estabelecida no art. 25. Este é um dos aspectos mais comemorados da lei, reconhecendo a capilaridade e presença das OSC na vida comunitária de nosso país. A liberdade de associação das entidades passa pela possibilidade delas se associarem umas às outras para criação das propostas e alternativas de enfrentamento das questões sociais que se colocam. Essa liberdade é característica do campo das OSC e o Estado pode estabelecer parcerias com essas entidades para enfrentar os desafios sociais. Por isso, proporcionar a atuação em rede é fundamental e muito bem-vindo.

Todavia, ao estabelecer as regras para esse trabalho em rede, há muitos requisitos burocráticos e sem justificativa razoável, como exigir, no momento da celebração da parceria, que a OSC apresente o rol de organizações em rede que vão participar da execução das atividades, retirando da OSC a prerrogativa de escolher, de forma autônoma, a sua própria rede. Hoje tramita no Congresso Nacional a apreciação de emendas propostas à Medida Provisória MP 658, que melhoram os dispositivos originais da Lei.

O dispositivo do $\S^{\circ}$, do art. 63 , estabelece normas diferenciadas para a prestação de contas nas parcerias cujo valor seja inferior a $R \$ 600$ mil, demonstrando clara indicação de que as parcerias de menor valor e complexidade devem ser objeto de procedimentos simplificados, em atenção ao princípio da proporcionalidade.

A exigência de contrapartida financeira foi afastada pela Lei $\mathrm{n} \times 13.019 / 2014$ que, na redação do parágrafo único, do inciso $\mathrm{V}$, do art. 35 , estabelece que esta não possa ser exigida como requisito para a celebração da parceria. Nesse sentido, 
reconhece a capacidade e acervo técnico das instituições como a contrapartida natural que elas oferecem ao Estado nas relações de parceria. A vedação à exigência de contrapartida financeira também é considerada um aspecto que favorece a participação de organizações com menor disponibilidade financeira.

$\mathrm{O}$ art. 72 reconhece três possibilidades com relação à avaliação da prestação de contas apresentada pelas OSCs, quais sejam: regulares, irregulares ou regulares com ressalva, assim entendidas aquelas que evidenciem impropriedade ou falta de caráter formal que não resulte dano ao Erário.

Por fim, a lei autorizou a criação do Conselho Nacional de Fomento e Colaboração, nos termos da redação do art. 15:

\begin{abstract}
Art. 15. Poderá ser criado, no âmbito do Poder Executivo federal, o Conselho Nacional de Fomento e Colaboração, de composição paritária entre representantes governamentais e organizações da sociedade civil, com a finalidade de divulgar boas práticas e de propor e apoiar políticas e ações voltadas ao fortalecimento das relações de fomento e de colaboração previstas nesta Lei.

$\S 1^{\circ}$ A composição e o funcionamento do Conselho Nacional de Fomento e Colaboração serão disciplinados em regulamento.

§2ำ Os demais entes federados também poderão criar instância participativa, nos termos deste artigo.
\end{abstract}

Os Conselhos de Fomento e Colaboração terão sua finalidade relacionada à divulgação de boas práticas, proposição e apoio a políticas e ações de fortalecimento e garantia da independência das OSC em geral, inclusive nas suas relações de parceria.

Uma vez constituídos, esses Conselhos deverão também atuar de forma transversal na Administração Pública, para buscar harmonizar e promover entendimentos com relação às normas incidentes sobre as parcerias entre OSC e o Estado.

Como se vê, a Lei nำ13.019/2014 traz muitas novidades para o universo das parcerias entre OSC e a Administração Pública. Tanto é assim que o fato que motivou a apresentação da Medida Provisória nํ58, de 29 de outubro de 2014, foi que o início da vigência da lei fosse adiado para julho de 2015, com base na solicitação de representantes de organizações da sociedade e de entes públicos, para possibilitar que se estruturem para implementá-la. 


\subsection{OS MECANISMOS DE MODULAÇÃO PARA APLICAÇÃO DA LEI $13.019 / 2014$}

Considerando a extensa gama de atividades que podem ser desempenhadas pelas OSC no escopo da Lei 13.019/2014, por meio da celebração dos respectivos Termos de Fomento ou Termos de Colaboração, parece-nos inevitável enfrentar a questão da aplicação do direito público e do direito privado sobre as diferentes parcerias celebradas.

A nova lei não foge ao desafio. Fica clara a opção do legislador em proporcionar elementos para a calibração da incidência de normas de direito público sobre as parcerias entre Estado e OSC, tendo, inclusive, estabelecido algumas garantias nesse sentido, como também normas cujo destinatários são os órgãos de fiscalização administrativa, que deverão reestruturar sua atuação a partir da nova organização administrativa proposta para as parcerias com OSC, dentro da Política de Fomento e Colaboração.

Dentre estas normas, destacamos o teor do $\S 4^{\circ}$ do art. 64 da Lei, que impõe ao processo de análise das prestações de contas das parcerias realizadas pelas OSC o dever se observar a proporcionalidade das regras de acordo com o montante de recursos repassados, além dos conteúdos dos Termos de Fomento ou de Colaboração celebrados, e dos Planos de Trabalho:

Art. 64. A prestação de contas apresentada pela organização da sociedade civil deverá conter elementos que permitam ao gestor da parceria avaliar o andamento ou concluir que o seu objeto foi executado conforme pactuado, com a descrição pormenorizada das atividades realizadas e a comprovação do alcance das metas e dos resultados esperados, até o período de que trata a prestação de contas.

$\$ 4^{\circ} \mathrm{A}$ prestacão de contas da parceria observará regras específicas de acordo com o montante de recursos públicos envolvidos, nos termos das disposicões e procedimentos estabelecidos conforme previsto no plano de trabalho e no termo de colaboração ou de fomento. 
A Lei prevê ainda outros elementos para adequada modulação das normas aplicáveis: A sua aplicação a diferentes entes públicos (art. , II); a diversidade do universo das OSC (lembre-se que a Lei equipara até mesmo os serviços sociais autônomos a OSC, para fins de sua aplicação); a diferenciação entre Termo de Fomentos e Termo de Colaboração (a indicar a realização de atividades administrativas diversas); princípios e diretrizes orientadores da sal aplicação; regras simplificadas para parcerias abaixo de $\mathrm{R} \$ 600$ mil; prevalência do Regulamento próprio da OSC para normatizar suas relações de contração de bens e serviços; a sua não aplicação aos Contratos de Gestão das Organizações Sociais; a sua aplicação, no que couber, aos Termos de Parceria das OSCIPs; a prevalência da verdade real e do controle por resultados quando da análise das prestações de contas.

Estes dispositivos, em conjunto, reconhecem o caráter privado e autônomo das OSC e possibilitam o estabelecimento de uma classificação gradativa que oriente a derrogação das normas de direito privado pelo direito público, a partir da característica do objeto da relação estabelecida entre ente público e a organização da sociedade civil.

No caso concreto, dever-se-á avaliar, ainda: a eventual definição de aspectos do regime jurídico especificamente previsto em lei; as fontes de financiamento (públicas ou privadas) da atividade ou serviço; o histórico do serviço; o público atendido; e as obrigações assumidas nos instrumentos de parceria celebrados entre as partes.

Da forma como a lei 13.019/2014 trata a matéria, é possível caminhar no sentido de superar alguns dos aspectos jurídicos problemáticos das parcerias: (i) a confusão entre a regulamentação das relações de cooperação entre entes públicos e as relações de cooperação entre o Estado e organizações privadas da sociedade civil; (ii) a ausência de diferenciação na regulamentação das parcerias entre as atividades administrativas fomento e de delegação.

Como regra geral, é natural que as atividades de fomento tenham um nível de derrogação das normas de direito privado pelas normas de direito público muito menor que as atividades de delegação, na medida em que, nesta última, é o Estado quem determina e precifica os serviços, enquanto, naquelas, o Estado identifica e 
apoia atividades que vinham sendo desenvolvidas pelas organizações privadas do terceiro setor. 


\section{CONSIDERAÇÕES FINAIS}

A liberdade de associação é um direito fundamental composto por três dimensões de direitos, ligados à: (i) não interferência estatal nas OSC; (ii) participação das organizações legalmente constituídas para fins lícitos, num Estado Democrático; (iii) obrigação do Estado de criar políticas que possibilitem que essas organizações captem recursos privados e acessem recursos públicos para o desenvolvimento de suas atividades de interesse comum (financiamento).

Os elementos essenciais que caracterizam as organizações da sociedade civil são os seguintes (i) entidades privadas; (ii) sem fins lucrativos; (iii) institucionalizadas; (iv) autoadministradas; e (v) voluntárias. A manutenção desses requisitos é fundamental para assegurar que essas organizações existam, desenvolvam-se e fortaleçam-se livremente.

Toda legislação que se disponha a tratar do tema das OSC deve levar em conta essas premissas, em respeito à Constituição Federal de 1988 e às normas de direitos humanos internacionais ratificadas pelo Brasil. Uma lei que fragilize as OSC num dos seus aspectos essenciais ou que imponha dificuldades ao livre exercício da liberdade de associação, em qualquer uma de suas dimensões, será uma barreira ao desenvolvimento da pluralidade, da diversidade e de outros valores essenciais à democracia.

O histórico recente da produção de normas voltadas às OSC no Brasil dividese em cinco fases distintas: (i) redemocratização - CF 1988; (ii) participação primeira metade da década de 90; (iii) contratualização - segunda metade da década de 90; (iv) controle - de 2003 a 2011; e (v) organização - final de 2011 até os dias atuais.

O programa do Marco Regulatório das OSC, iniciado no final de 2011 marca o início da fase de organização, tendo buscado organizar essas premissas e trabalhar de forma propositiva para implementá-las, tanto na perspectiva jurídica, de (re)adequação das normas, como na perspectiva de conhecimento, com a produção de estudos, identificação e apoio à formação de redes de pesquisadores e capacitações. 
Entre as principais mudanças legislativas impulsionadas pelo programa, destacam-se a alteração na questão da remuneração de dirigentes (Lei no12.868/2013) e a nova Lei de Geral de Parceiras das OSC (Lei ㄲo13.019/2014). Ambas trouxeram importantes novidades para temas que historicamente nunca foram tratados adequadamente pela legislação e cujos principais destaques foram brevemente apresentados neste artigo. Essas novas leis consolidam entendimentos, apontam caminhos e criam desafios adicionais para a vida das organizações da sociedade civil.

Apesar do reconhecimento, pelo programa do Marco Regulatório das OSCs, das características das OSCs, da liberdade de associação e da importância de uma sociedade civil livre e plural, ao tramitar no legislativo, os projetos de lei avançaram em alguns aspectos, mas criaram novas dificuldades em outros.

A Lei 13.019/2014 marca uma profunda mudança na organização administrativa, cria a Política de Fomento e Colaboração e estabelece a existência de mecanismos de modulação para a prestação de contas dessas parcerias. É provável que com o início da vigência da Lei se inicie uma nova fase das relações entre Estado e OSC, com o reconhecimento de uma nova política pública: a política de Fomento e Colaboração.

O permanente envolvimento da sociedade no aprofundamento dos temas ligados ao marco jurídico-institucional das OSC e o acompanhamento da implementação e interpretação da nova lei deverão merecer toda a atenção das organizações da sociedade civil a fim de que esse novo marco possa contribuir para a criação de uma cultura administrativa na matéria, capaz de respeitar as características das OSC, a liberdade de associação, nas suas três dimensões superar barreiras ao livre desenvolvimento das OSC no Brasil. 


\section{REFERÊNCIAS}

ABONG. Sustentabilidade das ONGs no Brasil: acesso a recursos privados. Rio de Janeiro: Abong, 2010.

ABRUCIO, Fernando Luiz; LOUREIRO, Maria Rita. Finanças públicas, democracia e accountability. In: ARVATE, Paulo; BIDERMAN, Ciro (Orgs.). São Paulo: FGV, Campus/Elsevier, 2005.

AKERLOF, George. The Market for Lemons: Quality Uncertainty and the Market Mechanism. Quarterly Journal of Economics, v. 84, n. 3, p. 488-500, ago. 1970.

ALEXY, Robert. Teoria dos direitos fundamentais. Trad. Virgílio A. Da Silva. São Paulo: Malheiros, 2008.

ALVES, Francisco de Assis. Fundações, organizações, agências executivas: organizações da sociedade civil de interesse público e demais modalidades de prestação de serviços públicos. São Paulo: LTr, 2000.

AMARAL, Ana Valeska. Terceiro Setor e Políticas Públicas. Revista do Serviço Público, Brasília, Ano 54, n. 2, p. 33-57, abr./jun. 2003.

ARMANI, D. Sustentabilidade: desafio democrático. In: FIEGE, H-J. Ongs no Brasil: perfil de um mundo em mudança. Fortaleza: Fundação Konrad Adenauer: 2003.

BALEEIRO, Aliomar. Direito Tributário Brasileiro. 10. ed. Rio de Janeiro: Forense, 1996.

BAMBINI DE ASSIS, Luiz Gustavo. Processo legislativo e orçamento público. Função de controle do Parlamento. São Paulo: Saraiva, 2012.

BANDEIRA DE MELLO, Celso Antônio. A democracia e suas dificuldades contemporâneas. In: BANDEIRA DE MELLO, Celso Antônio Bandeira de. Grandes Temas de Direito Administrativo. São Paulo: Malheiros, 2009. p. 372.

. Curso de Direito Administrativo. São Paulo: Malheiros, 2004. 
- Serviço Público e Atividade Econômica: Serviço Postal. São Paulo: Malheiros, 2009. (Grandes Temas de Direito Administrativo).

BANDEIRA DE MELLO, Oswaldo Aranha. Contrato de direito público ou administrativo. Revista de Direito Administrativo, v. 94, out./dez., 1968.

BARBOSA, Maria Nazaré Lins. A experiência dos termos de parceria entre o poder público e as organizações da sociedade civil de interesse público (OSCIPs). In: SUNDFELD, Carlos Ari (Coord.). Parcerias público-privadas. São Paulo: Malheiros, 2005. p. 487-523.

BARBOZA DA SILVA, Maria das Graças Bigal; VIEGAS DA SILVA, Ana Maria. Terceiro Setor. Gestão das entidades sociais (ONG - OSCIP - OS). Belo Horizonte: Fórum, 2008.

BELLI, Benoni. A politização dos direitos humanos. São Paulo: Perspectiva, 2009.

BOBBIO, Noberto. A Era dos Direitos. 8. ed. Rio de Janeiro: Campus, 1992.

BORGES, Alice Gonzalez. Democracia participativa. Reflexões sobre a natureza e a atuação dos conselhos representativos da sociedade civil. Revista Eletrônica sobre a Reforma do Estado (RERE), Salvador, Instituto Brasileiro de Direito Público, n. 14, jun./jul./ago. 2008. Disponível em: <http://www.direitodoestado.com.br/rere.asp>. Acesso em: 01 dez. 2012.

BORGES, Ivo de Souza. O controle social e a transparência pública na democracia brasileira. Revista CGU, Ano VI, jul. 2011.

BRASIL. Relatório do Grupo de Trabalho sobre o Marco Regulatório das Organizações da Sociedade Civil, criado pela Secretaria Geral da Presidência da República para elaborar propostas voltadas ao aperfeiçoamento de relações de parceria entre organizações da sociedade civil e entidades sem fins lucrativos. Brasília: Secretaria Geral da Presidência da República, agosto de 2012. Disponível em: <http://www.secretariageral.gov.br/mrosc/historico-1/relatorio>. Acesso em: 25 ago. 2014.

BRESSER-PEREIRA, Luiz Carlos. Instituições, bom estado e Reforma da Gestão Pública. In: ARVATE, Paulo; BIDERMAN, Ciro (Orgs.). São Paulo: Fgv, Campus/Elsevier, 2005. 
- Reforma do Estado para a cidadania: a reforma gerencial brasileira na perspectiva internacional. Brasília: ENAP, 1998.

BRITO, Carlos Ayres. Distinção entre "controle social do poder" e "participação popular”. Revista de Direito Administrativo, n. 189, jul./set. 1992.

CARRAZA, Roque Antonio. Curso de Direito Constitucional Tributário. São Paulo: Malheiros, 2006.

CARVALHAES NETO, Eduardo Hayden. O Serviço Público no Direito Administrativo Contemporâneo. In: DI PIETRO, Maria Sylvia Zanella; RIBEIRO, Carlos Vinícius Alves (Coords.). Supremacia do Interesse Público e Outros Temas Relevantes de Direito Administrativo. São Paulo 2011, p.365-377.

CARVALHO, Maria do Carmo Brant. Assistência Social: reflexões sobre a política e sua regulação. Serviço Social \& Sociedade, n. 87, 2006.

. Gestão Social: alguns apontamentos para o debate. In: RICO, Elizabeth de Melo; RAICHELIS, Raquel (Orgs.) Gestão social, uma questão em debate. São Paulo: Educ, Instituto de Estudos Especiais, PUC SP, 1999.

CARVALHO NETO, Antônio Alves de. Transferências de recursos do orçamento da União para organizações não governamentais: eficácia dos procedimentos de concessão e controle. Revista do TCU, v. 40, n. 112, p. 7-18, 2008.

CASTRO JR., Sérgio de; ROSSI, Sérgio Ciqueira. Convênios. Características principais e aspectos de interesse. Revista do Tribunal de Contas do Estado de São Paulo, no115, jul./ago. 2006.

COMPARATO, Fábio K. A Afirmação Histórica dos Direitos Humanos. 7. ed. São Paulo: Saraiva, 2010.

CEAPG - CENTRO DE ESTUDOS EM ADMINISTRAÇÃO PÚBLICA E GOVERNO DA EAESP Y ARTICULAÇÃO D3 - DIÁLOGOS, DIREITOS E DEMOCRACIA FUNDAÇÃO GETÚlIO VARGAS. Pesquisa Arquitetura Institucional de Apoio às organizações da Sociedade Civil No Brasil. São Paulo: Fundação Getúlio Vargas (FGV), 2013. 
CONTI, José Maurício. Arts. 22 a 33. In: CONTI, José Maurício (Coord.). Orçamentos públicos. A Lei 4.320/1964 comentada. São Paulo: RT, 2010.

(CPI das ONGs. Requerimento n. 201 de 2007 - SF). Disponível em: <http://www.senado.gov.br>. Acesso em: 30 de outubro de 2014

CRETELLA JÚNIOR, José. Curso de Direito Administrativo. Rio de Janeiro: Forense, 1986.

DIAS, Maria Tereza Fonseca. O controle do Tribunal de Contas da União sobre as parcerias da administração pública com entidades do terceiro setor. Fórum de Contratação e Gestão Pública, v. 8 n. 88, p. 59-74, 2009.

DI PIETRO, Maria Sylvia Zanella. Direito Administrativo. 25. ed. São Paulo: Atlas, 2012. . Parcerias na Administração Pública. 9. ed. São Paulo: Atlas, 2012.

. O princípio da supremacia do interesse público: sobrevivência diante dos ideais do neoliberalismo. In: DI PIETRO, Maria Sylvia Zanella; RIBEIRO, Carlos Vinícius Alves (Coords.). Supremacia do interesse público e outros temas relevantes do direito administrativo. São Paulo: Atlas, 2010.

DOWBOR, Ladislau. Governabilidade e descentralização. Revista do Serviço Público, v. 118, n. 1, jan./jul. 1994.

DURÃO, Pedro. Convênios \& Consórcios Administrativos - gestão, teoria e prática. Curitiba: Juruá, 2004.

ESTÊVÃO, Ana Maria Ramos. Conselhos: forma de governo e de poder/forma de inserção democrática. Universidade e Sociedade, Ano XIII, n. 31, out. 2003.

ESTORNINHO, Maria João. Fuga para o Direito Privado. Coimbra: Almedinha, 2009.

FERNANDES, Rubem César. Privado, porém público: o terceiro setor na América Latina. 3. ed. Rio de Janeiro: CIVICUS, 2002.

FIGUEIREDO, Lúcia Valle. Curso de Direito Administrativo. São Paulo: Malheiros, 
2004.

FISHER, Rosa Maria. Estado, mercado e terceiro setor: uma análise conceitual das parcerias intersetoriais. Revista de Administração, v. 40, n. 1, 2001.

FRANÇA, Vladimir da Rocha. Reflexões sobre a prestação de serviços públicos por entidades do terceiro setor. Revista Trimestral de Direito Público, n. 42, 2003.

FURTADO, Celso. Formação Econômica do Brasil. 34. ed, São Paulo: Companhia das Letras, 2007.

GOMES, Emerson Cesar da Silva. A disciplina jurídica das transferências voluntárias. In: CONTI, José Maurício; SCAFF, Fernando Facury (Coord.). Orçamentos Públicos e Direito Financeiro. São Paulo: RT, 2011.

HAYES, Ben. Counter-terrorism, 'policy laundering' and the FATF: legalising surveillance, regulating civil society. Transnational Institute / Statewatch: Hague, 2012. em: $<$ http://www.tni.org/sites/www.tni.org/files/download/fatf report-update $0 . p d f>$. Acesso em: 25 ago. 2014.

HERMANY, Ricardo. O princípio da subsidiariedade e o direito social de Gurvitch: a ampliação das competências municipais e a interface com a sociedade. In: LEAL, Rogério Gesta; REIS, Jorge Renato dos (Orgs.). Direitos sociais \& políticas públicas. Desafios contemporâneos. Santa Cruz do Sul: Edunisc, 2005. Tomo 5.

HONORATO DOS SANTOS, Sérgio. O dever de prestar contas dos recursos repassados por convênio e o ônus da prova. Boletim de Direito Administrativo, n. 1, NDJ, jan. 2007.

IBGE (Instituto Brasileiro de Geografia e Estatística); IPEA (Instituto de Pesquisa Econômica Aplicada). As Fundações Privadas e Associações Sem Fins Lucrativos no Brasil. 2.ed. Rio de Janeiro: IBGE/IPEA, 2005. Disponível em: $<$ http://www.ibge.gov.br/home/estatistica/economia/fasfil/2005/default.shtm>. Acesso em: 01 fev. 2010.

INSTITUTO CULTIVA; ESCOLA DE GOVERNO DE SÃO PAULO. Dicionário de Gestão democrática: conceitos para a ação política de cidadãos, militantes sociais e gestores participativos. Belo Horizonte: Autêntica, 2007. 
INSTITUTO PARA O DESENVOLVIMENTO DO INVESTIMENTO SOCIAL - IDIS. Fundos Patrimoniais Vinculados - Proposta de Projeto de Lei. São Paulo: IDIS. 2014.

International Center for Not-For-Profit Law (ICNL) \& World Movement for Democracy Secretariat at the National Endowment for Democracy (ned). Defending Civil Society Report. Washington, DC, 2012. Disponível em: $<$ http://www.icnl.org/research/resources/dcs/DCS Report Second Edition English.p df $>$. Acesso em: 10 out. 2014.

JANNUZZI, Paulo de Martino. Indicadores para diagnóstico, monitoramento e avaliação de programas sociais no Brasil. Revista do Serviço Público, n. 56, p. 137160, abr.jun. 2005.

JANNUZZI, Paulo de Martino; MACHADO SILVA, Maria Rosângela F.; FARIA SOUSA, Mariana Almeida de. Estruturação de sistemas de monitoramento e especificação de pesquisas de avaliação, os problemas dos programas públicos são. Brasília: Caderno ENAP. Reflexões para Ibero-América. Avaliação de Programas Sociais, 2009.

JUNQUEIRA, Luciano Prates et al. Modernização do sistema de convênio da Administração Pública com a sociedade civil. Brasília: Ministério da Justiça, 2012. (Série Pensando o Direito). v. 41. Disponível em: $<$ http://participacao.mi.gov.br/pensandoodireito/wpcontent/uploads/2013/03/Volume-41.pdf>. Acesso em: 25 ago. 2014.

JUSTEN FILHO, Marçal. Comentários à Lei de Licitações e Contratos Administrativos. São Paulo: Dialética, 2005. . Curso de direito administrativo. São Paulo: Saraiva, 2005.

KENNEDY, David. The International Human Rights Movement: Part of the Problem? European Human Rights Law Review, v. 3, 2001.

LOPES, Laís de Figueirêdo; STORTO, Paula Raccanello. Alterações no Código Civil flexibilizam regras para instituições do Terceiro Setor. Disponível em: $<$ http://www.gife.org.br/artigo-alteracoes-no-codigo-civil-flexibilizam-regras-parainstituicoes-do-terceiro-setor-11533.asp >. Acesso em: 01 jul. 2013. 
- Convenção sobre os Direitos das Pessoas com Deficiência da ONU, seu Protocolo Facultativo e a Acessibilidade - Dissertação apresentada à Banca Examinadora da Pontifícia Universidade Católica de São Paulo - São Paulo, 2009, p.72

LUCKI, Patricia. Marcos Jurídicos de la Participación Cuidadana y las Organizaciones no Gubernamentales en México, Guatemala, Honduras, El Salvador y Nicaragua. Guatemala: Fundación para el Desarollo de la Innovación de Centroamerica, 2014. Disponível em: <http://mesadearticulacion.org/wpcontent/uploads/2014/07/Estudio-Marco-Jur\%C3\%ADdico-CentroAm\%C3\%A9rica.pdf>. Acesso em: 25 ago.2014.

MAIELLO, Anna Luiza Duarte. Aspectos Fundamentais do Negócio Jurídico Associativo. 2012. Tese (Doutorado em Direito) - Faculdade de Direito da USP, São Paulo, 2012.

MÂNICA, Fernando Borges. Terceiro Setor e Imunidade Tributária: Teoria e Prática. Belo Horizonte: Fórum, 2005.

MARQUES NETO, Floriano de Azevedo. Os grandes Desafios do Controle da Administração pública. In: MODESTO, Paulo (Coord.). Nova Organização Administrativa Brasileira. 2. ed.Belo Horizonte: Fórum, 2010.

- Do Contrato Administrativo à Administração Contratual. Revista do Advogado, v. 107, p. 74-82, 2009. P. 77.

MEDAUAR, Odete. Convênios e Consórcios Administrativos. Boletim de Direito Administrativo, n.8, 1995.

. Direto administrativo moderno. 2. ed. São Paulo: Revista dos Tribunais, 1998.

MELO, Marcus. Emendas Parlamentares. In: AVRITZER, Leonardo; ANASTASIA, Fátima (Org.). Reforma Política. Belo Horizonte: UFMG/PNUD, 2006.

MEIRELLES, Hely Lopes. Direito administrativo brasileiro. São Paulo: RT, 1978.

MENEZES DE ALMEIDA, Fernando. Liberdades públicas de ação coletiva: a posição do Supremo Tribunal Federal analisada à luz do Direito internacional dos direitos humanos. In: AMARAL JÚNIOR, Alberto do; JUBILUT, Liliana Lyra. (Orgs.). 
O STF e o Direito internacional dos direitos humanos. São Paulo: Quartier Latin, 2009. p. 190-209.

MILL, John Stuart. Sobre a Liberdade. Trad. Pedro Madeira. Rio de Janeiro: Nova Fronteira, 2011.

MODESTO, Paulo (Coord.). Nova Organização Administrativa Brasileira. 2. ed. Belo Horizonte: Fórum, 2010.

MOREIRA, Egon Bockmann. Terceiro Setor da Administração Pública. Organizações sociais. Contrato de Gestão. Revista de Direito Administrativo, n. 227, jan./mar. 2002.

MUSTAFA, Andrea. O Estado e as organizações da sociedade civil. Revista da Faculdade de Direito da Universidade de São Paulo, n. 95, 2000.

NÓBREGA, Marcos. Orçamento, eficiência e performance budget. In: CONTI, José Maurício; SCAFF, Fernando Facury (Coord.). Orçamentos Públicos e Direito Financeiro. São Paulo: RT, 2011.

NOGUEIRA, Marco Aurélio. Um Estado para a sociedade civil: Temas éticos e políticos da gestão democrática. São Paulo: Cortez, 2004.

OECD. Brasil precisa fortalecer o sistema de integridade do serviço público federal. Disponível em: $<$ http://www.oecd.org/document/51/0,3746,en 21571361443151154894437111 1 1,00.html>. Acesso em: 07 jan. 2012.

OLIVEIRA, Gustavo Justino de. Direito do Terceiro Setor. Revista de Direito do Terceiro Setor - RTDS, Ano 1, n. 1, jan./jun. 2007.

OSTROM, Elinor. Governing the Commons: The Evolution of Institutions for Collective Action. Cambridge: Cambridge University Press, 1990.

O'DONNELL, Guillermo; SCHMITTER, Philippe. Transições do Regime Autoritário Primeiras Conclusões. Trad. Adail U. Sobral. São Paulo: Vértice/Revista dos Tribunais, 1988. 
ONU. Declaração de Direito ao Desenvolvimento. 1986. Disponível em: $<$ http://www.eselx.ipl.pt/ciencias-sociais/tratados/1986.htm>. Acesso em: 03 jun. 2012.

PAIS COSTA, Daniela. Prestação de contas. In: SZAZI, Eduardo (Org.). Terceiro setor. Temas polêmicos. São Paulo: Peirópolis, 2005. v.2.

PASQUATTI, Norberto. O terceiro setor e os direitos sociais. In: PANTALEÃO, Leonardo (Org.). Fundações Educacionais. São Paulo: Atlas, 2003.

PAULINO, Luis Castillo; HUAMAN, Josefina. Estudio sobre los Marcos Jurídicos de las Organizaciones no Gubernamentales en la Región Andina. Lima: Asociación Nacional de Centros de Investigación, Promoción Social y Desarollo, ANC - Peru, 2014. Disponível em: $\quad<$ http://mesadearticulacion.org/wpcontent/uploads/2014/07/Estudio-Marcos-Jur\%C3\%ADdicos-Subregi\%C3\%B3nAndina.pdf >. Acesso em: 25 ago. 2014.

PIMENTA OLIVEIRA, José Roberto. Improbidade Administrativa e Terceiro Setor. In: PIRES, Luis Manuel Fonseca; ZOCKUN, Maurício; ADRI, Renata Porto (Coord.) Corrupção, Ética e Moralidade Administrativa. Belo Horizonte: Fórum, 2008.

PEREIRA, Luiz Carlos Bresser; GRAU, Nuria Cunill. O público não-estatal na reforma do Estado. Rio de Janeiro: FGV, 1999.

PIOVESAN, Flávia (Orgs.). Igualdade, Diferença e Direitos Humanos. Rio de Janeiro: Lumen Juris, 2008.

PIRES, Davi Ulisses Brasil Simões. O Cadastro Nacional de Entidades do Ministério da Justiça, uma ferramenta a serviço do público. In: PISCITELLI, Roberto Bocaccio. Organizações não-governamentais; fiscalização. Nota Técnica. Setembro, 2004. Disponível em: <http://www.camara.gov.br>.

PORTUGAL GOUVÊA, Carlos. Social Rights Against the Poor, Vienna. Journal on International Constitutional Law, v. 7, (2013) (no prelo)

POZZOLI, Lafayette. A dignidade humana na Constituição Federal de 1988. In: ALVIM, Marcia Cristina de Souza; POZZOLI, Lafayette (Org.) Ensaios sobre filosofia do Direito. Dignidade da Pessoa Humana. Democracia. Justiça. São Paulo: Educ/Fapesp, 2011. 
PRUDENTE, Eunice Aparecida de Jesus. Direito à personalidade integral: cidadania plena. Tese (Doutorado em Direito) - Universidade de São Paulo. 1996, p.13.

REGULES, Luis Eduardo Patrone. A legislação e os desafios do terceiro setor, Valor Econômico, 10/02/2009, Legislação, p. E2

. Terceiro Setor: Regime Jurídico das OSCIPs. São Paulo: Método, 2006.

RESENDE, Tomáz de Aquino. Novo Manual de Fundações. Belo Horizonte: Inédita, 1997.

RESENDE, Tomáz de Aquino et al. Associações e Fundações - Roteiro do Terceiro Setor. 4. ed. Belo Horizonte: PRAX, 2012.

REPORT of the Special Rapporteur on the rights to freedom of peaceful assembly and of association, Maina Kiai, Best practices related to the rights to freedom of peaceful assembly and of association - A/HRC/20/27, May, 21, 2012. Human Rights Council. Twentieth session. Agenda item 3. Promotion and protection of all human rights, civil, political, economic, social and cultural rights, including the right to development. em http://www.ohchr.org/Documents/HRBodies/HRCouncil/RegularSession/Session20/ A-HRC-20-27 en.pdf. Último acesso em 25/08/2014.

. The exercise of the rights to freedom of peaceful assembly and of association in the context of elections - A/68/299. August, 7, 2013. Disponível em: $<$ http://www.icnl.org/research/library/files/Transnational/specrap.pdf >. Acesso em: 17 ago. 2014.

Ability of associations to access financial resources as a vital part of the right to freedom of association \& Ability to hold peaceful assemblies as an integral component of the right to freedom of peaceful assembly - A/HRC/23/39, April, 24, 2013. <http://www.ohchr.org/Documents/HRBodies/HRCouncil/RegularSession/Session23/ A.HRC.23.39 EN.pdf>. Acesso em: 17 ago. 2014.

REZENDE, Flávio da Cunha. Razões da crise de implementação do Estado Gerencial: desempenho versus ajuste fiscal. Revista de Sociologia e Política. n. 19, nov. 2002. 
RIBEIRO, Romiro. Orçamento Público Semi-impositivo para transferências voluntárias: diagnóstico, perspectivas e propostas de mudanças. E-Legis, 1ํㅡㄴ semestre, n. 4, 2010.

ROCHA, Silvio Luís Ferreira da. Terceiro Setor. São Paulo: Malheiros, 2003.

ROCHAEL, Denise. Organizações do terceiro setor: uma abordagem comparativa de critérios contábeis de reconhecimento, mensuração e evidenciação brasileiros, estadunidenses e internacionais. 2009. 228fls. Dissertação (Mestrado em Ciências Contábeis) - Programa Multiinstitucional e Inter-regional de Pós-graduação em Ciências Contábeis, UnB, UFPB, UFRN, Brasília, 2009.

SALINAS, Natasha Shmitt Caccia. Avaliação Legislativa no Brasil: um estudo de caso sobre as normas de controle das transferências voluntárias de recursos públicos para entidades do terceiro setor. 2008. Dissertação (Mestrado em Direito) Usp, São Paulo, 2008.

SALIONE, Beatriz Camasmie Curiati. Terceiro setor e lei de licitações no Brasil. RDTS, v. 4, n. 8, p. 75-90, 2010.

SALOMÃO FILHO, Calixto; Menos Mercado. In: DIREITO Empresarial e outros estudos em homenagem ao Professor Josë Alexandre Tavares Guerreiro. São Paulo: Quartier Latin, 2012.

FERRÃO, Brisa Lopes de Mello; RIBEIRO, Ivan César. Concentração, Estruturas e Desigualdade: As origens coloniais da pobreza e da má distribuição de renda. São Paulo: Idcid, 2006.

Novo Estruturalismo Jurídico: uma alternativa para o Direito? Revista dos Tribunais, Ano 101, edição comemorativa dos 100 anos, v. 926, dez. 2012.

SANTOS, Boaventura de Souza. "Para uma Concepção Intercultural dos Direitos Humanos". In: SARMENTO, Daniel; Ikawa, Daniela e PIOVESAN, Flávia (Orgs.). Igualdade, Diferença e Direitos Humanos. Rio de Janeiro: Editora Lumen Juris, 2008, p. 29.

SANTOS NETO, João Antunes dos. O Impacto dos Direitos Humanos Fundamentais no Direito Administrativo. Belo Horizonte: Fórum, 2008. 
SÃO PAULO. Tribunal de Contas do Estado de São Paulo. Manual básico: repasses públicos ao terceiro setor. São Paulo: Imprensa Oficial, 2004.

SCARPINELLA, Vera; SUNDFELD, Carlos Ari. Fundações educacionais e licitação. In: PANTALEÃO, Leonardo (Org.). Fundações educacionais. São Paulo: Atlas, 2003. p. 248-259.

SCHIRATO, Vitor Rhein. Livre Iniciativa nos Serviços Públicos. Belo Horizonte: Fórum, 2012.

SECCHIN, Lenise Barcellos de Mello. Controle social: transparência das políticas públicas e fomento ao exercício de cidadania. Revista da CGU, Ano III, n. 5, dez. 2008.

SEN, Amartya. Desenvolvimento como liberdade. São Paulo: Companhia das Letras, 2000.

A ideia de Justiça. São Paulo: Companhia das Letras, 2009.

SILVA, José Afonso da. Curso de Direito Constitucional Positivo. 29. ed. São Paulo: Malheiros, 2007, p. 266.

SIMÕES PIRES, Maria Coeli. Terceiro Setor e as Organizações Sociais. Boletim de Direito Administrativo, n. 4, abr. 1999.

. Esgotamento do modelo de desenvolvimento excludente no Brasil e ressemantização das atividades de planejamento e articulação governamentais à luz do paradigma democrático. In: MODESTO, Paulo (Coord.). Nova organização administrativa brasileira. Belo Horizonte: Fórum, 2009.

SOUZA, Paulo Sérgio Bravo (Coord.). Eficácia no terceiro setor: sistema de avaliação de impactos sociais: 40 anos da Ação Comunitária. São Paulo: Saint Paul, 2009.

SUNDFELD, Carlos Ari (Coord.). Parcerias público-privadas. São Paulo: Malheiros, 2005. 
. As modernas parcerias públicas com o terceiro setor. A\& $C$ : revista de direito administrativo e constitucional, v.11, n. 43, p. 57-89, 2011.

STORTO, Paula Raccanello. A incidência do Direito Público sobre as Organizações da Sociedade Civil sem Fins Lucrativos. In: DI PIETRO, Maria Sylvia Zanella; RIBEIRO, Carlos Vinícius Alves (Coords.). Direito Privado Administrativo. São Paulo: Atlas, 2013.

- Informe sobre o Marco Juridico de las Organizaciones de la Sociedad Civil en America Latina y Caribe, preparado para o Proyecto Regional de la Mesa de Articulación de Plataformas de OSC de América Latina y el Caribe. São Paulo, 2014.

SZAZI, Eduardo. NGOS. Legimate Subjects of Internacional Law. Thesis PhD, International Law. Universiteit Leiden, 2013.

. Terceiro Setor - Regulação no Brasil. 4. ed. São Paulo: Peirópolis, 2006.

Terceiro Setor Temas Polêmicos. São Paulo: Peirópolis, 2005. v.2.

. Terceiro Setor Temas Polêmicos. São Paulo: Peirópolis, 2004. v.1.

TAVARES, André Ramos. As organizações sociais no STF. Carta Forense, maio de 2011. Disponível em: <http://www.cartaforense.com.br/Materia.aspx?id=6992>. Acesso em 30 de outubro de 2014.

TCU. Licitações e Contratos. Orientações e Jurisprudência do TCU. Brasília: editora, 2010.

Convênio - Alteração do objeto conveniado. Inexistência de Prévio Conhecimento e Autorização do Concedente. Irregularidade na aplicação de recursos transferidos. Pessoa Jurídica não-integrante da Administração Pública. Responsabilidade do Dirigente da Entidade - Aplicação de multa. Boletim de Direito Administrativo, n. 10, out. 2009. 
TEDx Liberdade - Advancing our world through Civil Society Action - The Power of Together. Talks. São Paulo: 2014. Disponível em: <http://www.tedxliberdade.com/>. Acesso em: 15 ago. 2014.

TEIXEIRA, Ana Claudia Chaves. A atuação das organizações não-governamentais: entre o Estado e o conjunto da sociedade. In: DAGNINO, Evelina (Org.). Sociedade civil e espaços públicos no Brasil. São Paulo: Paz e Terra, 2002.

TOURINHO, Rita. Terceiro Setor no ordenamento jurídico brasileiro: constatações e expectativas. Revista Brasileira de Direito Público, v. 8, n. 30, p. 117-138, jul./set. 2010.

TORRES, Miriam Cavalcanti de Gusmão Sampaio. O convênio administrativo de saúde pública. Advocacia Pública, n. 16, dez. 2001.

TOZZI, José Alberto. Prestação de Contas no Terceiro Setor: A Dicotomia do Marco Regulatório. 2010. Dissertação (Mestrado em Administração) - Faculdade de Administração da Pontifícia Universidade Católica de São Paulo, São Paulo, 2010.

VERAS NETO, Francisco Quintanilha. O terceiro setor, reorganização autogestionária da sociedade civil ou neoliberalismo disfarçado? Revista Crítica Jurídica, n. 18, p. 215-235, jun. 2001.

Terceiro Setor e as Parcerias com a Administração Pública - uma análise critica. Belo Horizonte: Fórum, 2006.

VIVEROS, Felipe. Sintesís Comparativa: Marcos Jurídicos de las Organizaciones de la Sociedad Civil en los Paises del Cono Sur e Brasil. Santiago: Asociación Chilena de Organismos No Gubernamentales - ACCIÓN, documento preparado para el Proyecto Regional Mesa de Articulación de América Latina y el Caribe y sus Aliados del Sur, $2014 . \quad$ Disponível em: <http://mesadearticulacion.org/wpcontent/uploads/2014/08/Estudio-Subregional-marco-legal-OSCs-Cono-Sur.pdf>. Acesso em 31 de outubro de 2014 